\title{
A Vision of Energy Structure for Integrated Steel Works of Future*
}

\section{By Tetsuya YAMAMOTO** and Tadashi NAKAGAWA**}

\section{Introduction}

The 4th Middle East War that broke out in 1973 and the OPEC's petroleum strategy that was taken subsequently had shaken from its foundations the Japanese economy, which was then growing at a high rate supported by unlimited and inexpensive oil. We call this the First Oil Crisis or the First Oil Shock. At that time, Japan had been dependent on oil for $77 \%$ of the primary energy, and $99.8 \%$ of oil was imports. Therefore, a price rise in oil directly meant another price rise in all the other energies, coal, electricity, gas, and any other.

All the industries that operated on energy had to face the energy saving. Save petroleum, save electric power, save coal-any and sundry energies were the target for the economization movement. Instead of the labor saving of the high rate growth time, the energy saving came to the fore.

By nature, the iron- and steel-making is an industry that bases itself on coal. Therefore, its dependence on oil had traditionally been low-about $20 \%$ at most. Yet, the quantity it used to consume was huge: it was 13.5 million $\mathrm{k} l$, or as much as 15.5 million $\mathrm{k} l$ with kerosene and LPG included, in the FY* 1973. When reckoned in terms of the total energy with coal and electric power taken into account, the iron and steel industry was consuming some $18 \%$ of the national total, the indubitable leader in the mining and manufacturing industries sector.

To overcome the First Oil Shock, every steel firm had started tackling the energy saving problems by establishing an organization that centrally controls energies, and by determining the control indexes and saving targets. It was an allout effort at anything that might lead to energy saving. Through the FYs 1974 to 1978, it was mostly technical improvements done at the operation ends, yet 8 to $9 \%$ reduction was gained in the overall rate as the steel industry as a whole. We call this the First Round Energy Saving.

Then, the Second Oil Shock due to Iranian Revolution struck to bring about further price rise and uncertainty of supply. The price leapt up from slightly over $12 \$ /$ bbl to 26 to 30 , a 2.5 -fold increase, which, even though it was smaller percentagewise than that of the lst Oil Shock of 4-fold, was far greater in the absolute amount. Saving of energies, especially that of oil, had to be reinvigorated.

At that time, there was this to think about: even after the oil became quite expensive by the lst Oil Shock, the coking coal was actually more expensive than the oil, but the 2nd Oil Shock brought about a reversal in the matter. That is, the price ratio of oil to coal (as coke), when reckoned in terms of calorific value, was enlarged to 2 to 2.5 times. This meant that, even though more had to be spent in coal or coke-even though contrary to the ideal of energy saving-more could be saved in cost.

One typical result was the curtailment of the oil for blast furnace (BF) injection. This movement started early with small and medium size BFs and spread gradually to large BFs to become the all coke, or the no oil, operation that is now quite universal.* Although maintenance of high tapping rate (TR) and occurrence of operational difficulties were yet to be feared, every steel firm had gone almost entirely into the all coke practice by the spring of 1981 .

As the all coke operation spread, more coke came to be needed, and that much more of coke oven gas (COG) came to be had in hand. Traditionally, in an integrated iron and steel works, besides the COG, various byproduct gases like BFG (blast furnace gas) and LDG (LD converter gas) have been utilized as fuels not only for hot stoves, coke ovens, and sintering, but at the down stream apparatuses like reheating furnaces and heat treatment furnaces (mainly COG) as well as for boilers (mainly BFG and LDG). This was a reason, when assisted by the energy saving techniques developed specifically for those apparatuses and by the improved gas recovery, of the great saving of fuel oil actually achieved. This state of affairs is shown in Table 1 and exemplified in Fig. 1.

And so, a new era in energy saving, that evolved out of sheer reduction of per tonnage crude steel energy rate into a higher order energy policy making, a policy that considers future supply/demand relationships by the species (for example, for kerosene and for light oil individually) as well as the total energy balance (for example, what to do with excess BFG), has dawned. This we call the Second Round of energy saving.

This Nishiyama Seminar has been prepared by the present authors for the Energy Saving Technologies

\footnotetext{
* Presented to the 80th, 81st Nishiyama Seminars, February \& March 1982, at Kitakyushu-shi Kinrōsha Kaikan Hall in Kitakyushu, and at Nokyo Hall in Tokyo. Manuscript received May 23, 1983.

** Energy Control Dept., Head Office, Sumitomo Metal Industries, Ltd., Kitahama, Higashi-ku, Osaka 541.

*** Energy Planning \& Coordination Div., Head Office, Nippon Steel Corporation, Otemachi, Chiyoda-ku, Tokyo 100.

$\dagger \quad$ The Japanese Fiscal Year starts on April 1 and ends on March 31.

t† Though there were (still are) instances of tar injection, tar is a coal-derivative fuel.
} 


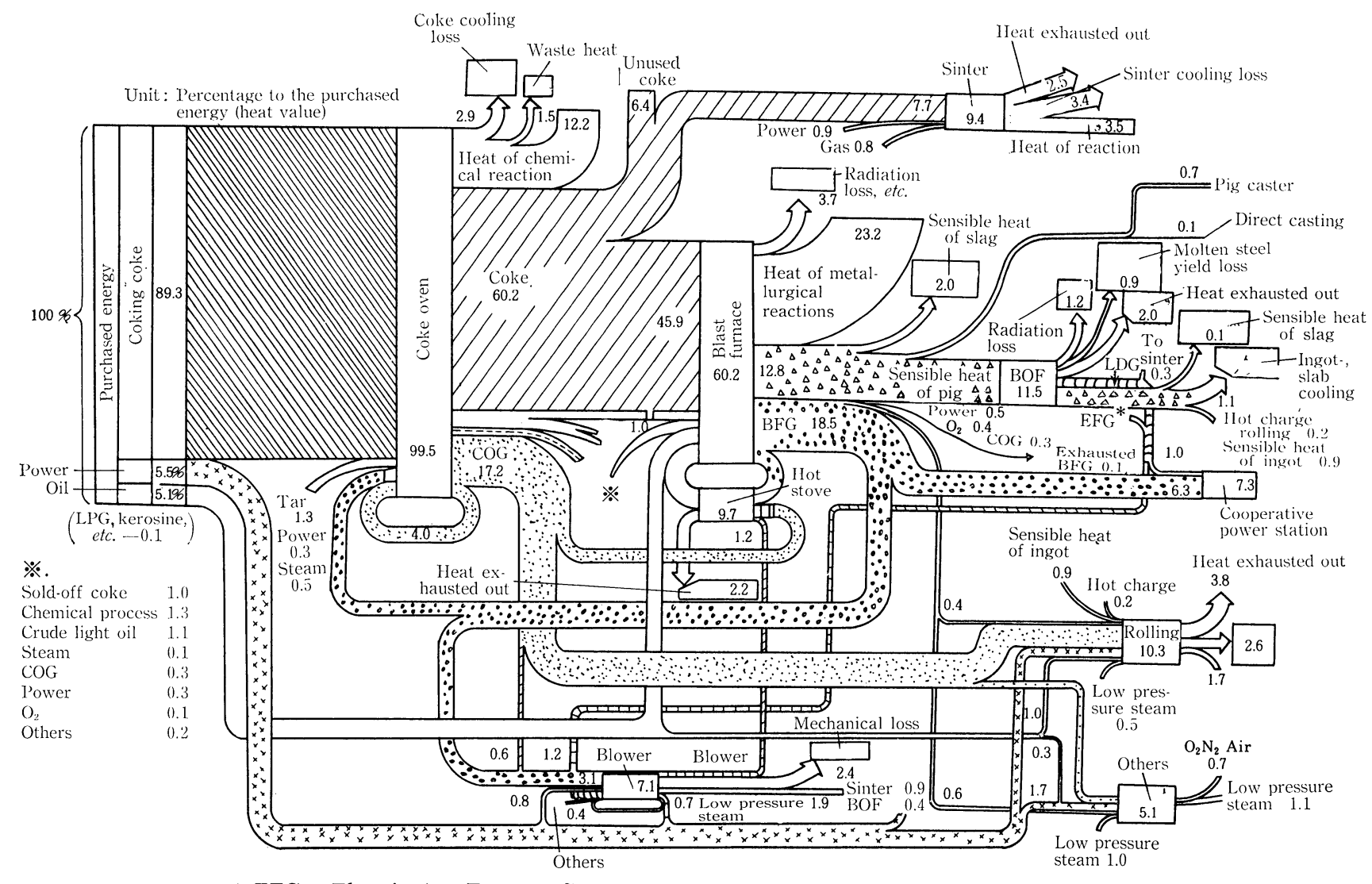

* EFG: Electric Arc Furnace Gas

Fig. 1. An example of energy flow of an integraged iron- and steelmaking works. (Kashima Steel Works, Sumitomo Metal Industries, Ltd.)

Table 1. Consumption of petroleum fuels by the steel industry. (Unit : million $l$ )

\begin{tabular}{|c|c|c|c|c|c|}
\hline & Fiscal year & 1973 & 1978 & 1980 & $\begin{array}{l}\text { '80/'73 } \\
\text { ratio }\end{array}$ \\
\hline & Blast furnace & 5246 & 2935 & 1067 & 0.203 \\
\hline :ี & Rolling plants & 4983 & 2303 & 1868 & 0.375 \\
\hline 5 & Power boilers & 1527 & 1123 & 514 & 0.337 \\
\hline 空 & Others & 1707 & 864 & 671 & 0.393 \\
\hline & Sum & 13463 & 7225 & 4120 & 0.306 \\
\hline & Kerosene & 500 & 751 & 587 & 1.174 \\
\hline 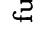 & Light oil & 350 & 151 & 99 & 0.283 \\
\hline$\xi$ & Naphtha, etc. & 153 & - & - & - \\
\hline 苞 & LPG & $\begin{array}{l}984 \\
(800 \mathrm{kt})\end{array}$ & $\begin{array}{l}1237 \\
(1006 \mathrm{kt})\end{array}$ & $\begin{array}{l}822 \\
(668 \mathrm{kt})\end{array}$ & 0.835 \\
\hline$\vec{\Xi}$ & LNG & $\begin{array}{l}34 \\
(25 \mathrm{kt})\end{array}$ & $\begin{array}{l}284 \\
(210 \mathrm{kt})\end{array}$ & $\begin{array}{l}292 \\
(216 \mathrm{kt})\end{array}$ & 8.588 \\
\hline$\overleftarrow{0}$ & Sum & 2021 & 2423 & 1800 & 0.891 \\
\hline & nd sum & 15484 & 9648 & 5920 & 0.382 \\
\hline & un & 128 & 92 & 55 & 0.430 \\
\hline
\end{tabular}

Source: MITI “Tekko Tokei Geppo (Iron \& Steel Monthly Statistics)" as compiled by JISF

Research Group of the Heat Economy Technology Committee, the Joint Research Society of ISIJ. This Group was formed in April 1981, just when the government enacted the Energy Substitution Act and at the time when practically all the Japanese BFs had gone " oil-less", for the specific purposes of studying:
1) those energy saving technologies that are not for the individual processes or steps but will encompass more than two processes, or even the entire steel works,

2) how to promote the energy saving so as to be compatible with more immediate goals, such as, for example, realization of " oil-less" steel works,

3) those measures that will positively strengthen the steel works' adaptability to changes in energy situation, such as, for example, the all coke operation and reformation and utilization of byproduct gases,

and, as a consequence,

4) the overall evaluation of impacts of introducing energy saving measures or alternative fuels on the energy balance of an integrated iron and steel making works.

As every steel works differs from another in its line of products, scale of operation, age of equipment, layout, kind and quantity of energy to be consumed, and local circumstances, a model works was envisioned. Further, two bases were provided for each of the energy rates to be applied to the various processes of the Model. They are:

1) the Standard (STD) Bases, which are the best, or the most advanced, rates among those that were reported by the Committee member firms, except sometimes appropriately modified to fit to the Model works, so that the STD should be considered as a goal to be achieved by any firm within 
a few years of time, and

2) the Target (TGT) Bases, which are the ones either considered to be today's technological limit or presumed to be achievable only if further measures or new equipment (be it already available if yet uncommon or expected to become practical in the near future) were provided for.

It is believed that the Model Steel Works presented herein is generalized well enough so that the cases of real works should readily be indentified for quantitative comparison.

\section{Designing of the Model Steel Works}

To see the effects of energy saving measures and of operation variations to be taken by individual sectors on the overall energy structure of integrated iron and steel works, a hypothetical steel works of an yearly production capacity of 8 million t crude steel has been designed as a model. The figurative and numerical grounds were decided upon by consulting the IISI's "A Technological Study on Energy in the Steel Industry" (Committee on Technology, 1976) and JISF's "Research and Development of Total System-Study of Waste Heat Utilization Technology System" (1979).

In view of the actual operation of recent years, the capacity usage ratio (CUR) was set at $80 \%$, and the continuous casting rate (CCR) at $70 \%$ * There will be a coke oven plant, two $5000 \mathrm{~m}^{3} \mathrm{BFs}$, a lime calcination plant, three $300 \mathrm{t} / \mathrm{ch}$ basic oxygen (or LD) furnaces (BOF) working on two-by-three principle, three slab CG machines, a bloom CG machine, an ingotmaking plant, and rolling lines, both hot and cold, appropriately equipped with mills and furnaces. The products are, from the hot rolling plant, hot coils, medium thickness sheets (the pickled sheet steels), plates, bars and rods, and seamless pipes, while out of the cold rolling plant, cold strips, cold rolled sheets, galvanized sheets, and tinned sheets. This is shown in the material flow diagram of Fig. 2.

The major operation rates and parameters shown in Table 2 were decided upon on the basis of actual records attained by the member firms in FY 1978. Therefore, this Model with its oil injection at BF and relatively low CCR is to represent the state of affairs when the First Round Energy Saving was completed.

\section{Establishment of STD and TGT Rates for Individual Sectors}

\section{The Cokemaking Sector}

The coke ovens have become, in accordance with the marked enlargement and sophistication of BFs, larger, better automated, and better adaptable to changes in quality of coal. Besides, such large scale energy saving technologies as coke dry quenching (CDQ) or preheating of coal have spread widely. Yet, factors of coking operation, e.g., grade of coal, chemical composition including moisture, oven structure, and state of heating and combustion, remain to
Table 2. Major operation rates and parameters of the model steel works.

\begin{tabular}{|c|c|c|}
\hline Sector & Operation paramete & ers and rates \\
\hline Cokemaking & $\begin{array}{l}\text { Coal calorific value } \\
\text { Coal volatile matter } \\
\text { Coke oven CUR } \\
\text { Coke gross yield } \\
\text { Coke lump yield } \\
\text { Coke breeze ratio }\end{array}$ & $\begin{array}{c}7700 \mathrm{kcal} / \mathrm{kg} \text {-dry } \\
27 \% \\
100 \% \\
75 \% \\
65 \% \\
10 \%\end{array}$ \\
\hline Ironmaking & $\begin{array}{l}\text { Sinter yield } \\
\text { Sinter lump yield } \\
\text { Sinter fines ratio } \\
\text { (Return sinter) } \\
\text { BF coke rate } \\
\text { BF oil rate } \\
\text { BF sinter ratio } \\
\text { BF pellet ratio }\end{array}$ & $\begin{array}{l}98 \% \\
76.5 \% \\
23.5 \% \\
415 \mathrm{~kg} / \mathrm{t} \text {-pig } \\
35 \mathrm{~kg} / \mathrm{t}-\text { pig } \\
80 \% \\
10 \%\end{array}$ \\
\hline Steelmaking & $\begin{array}{l}\text { Hot metal rate } \\
\text { Lime rate } \\
\text { GC rate }\end{array}$ & $\begin{array}{l}0.92 \\
40 \mathrm{~kg} / \mathrm{t} \text {-steel } \\
70 \%\end{array}$ \\
\hline Ingotmaking & $\begin{array}{l}\text { Killed steel ratio in the } \\
\text { slab ingots } \\
\text { Killed steel ratio in the } \\
\text { billet ingots }\end{array}$ & $\begin{array}{l}12.5 \% \\
61 \%\end{array}$ \\
\hline Rolling & $\begin{array}{l}\text { Plate mill HGR } \\
\text { Hot strip mill HDR } \\
\text { Hot strip mill HCR } \\
\text { Bar mill HCR }\end{array}$ & $\begin{array}{l}30 \% \\
20 \mathrm{kt} / \text { month } \\
19 \% \\
50 \%\end{array}$ \\
\hline
\end{tabular}

be as complex and mutually interactive as ever, so that no comprehensive theoretical analysis method is available.

Therefore, the rates, oven dimensions, and such were determined by taking statistical average of reported results. As for the Chemical Division, on the other hand, as the process itself differs greatly from a firm to another, several representative cases were selected and their average was adopted.

\section{The Chemical Division}

The chemical process was limited to the refining of COG as shown in Fig. 3. The STD rates are the values that appeared to be the best among the reported achievements. Further, as no remarkable accomplishments in energy saving were found, the TGT rates were taken as the same as STD. Those values are listed in Table 3.

\section{Determination of STD and TGT Rates and Operation Parameters}

(1) Correlations among Operation Parameters

The two great factors of coke oven operation that affect on energy saving are the volatile matter (VM) value of the coking coal and the GUR (capacity usage ratio). As may be seen in Table 4, all the operation parameters were found representable by respective correlation equation of first order when the actual experiences of 12 coke ovens were averaged over and modified by the expected effects of energy saving

* Today it is already $80 \%$ or even more, see Iki, Tetsu-to-Hagané, 69 (1983), 7. 


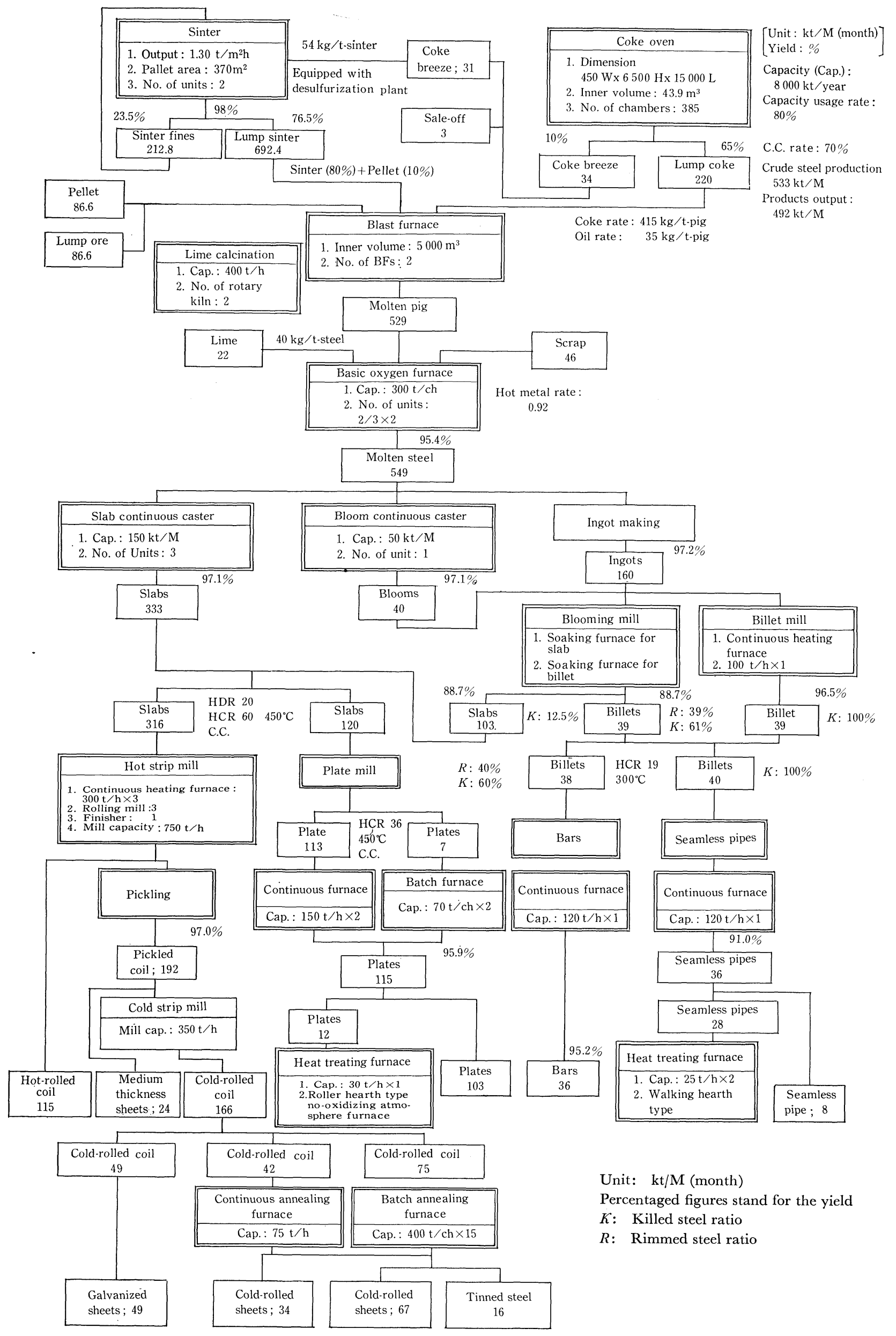

Fig. 2. Materials flow diagram for the model 8 million $\mathrm{t}$ steel works. 


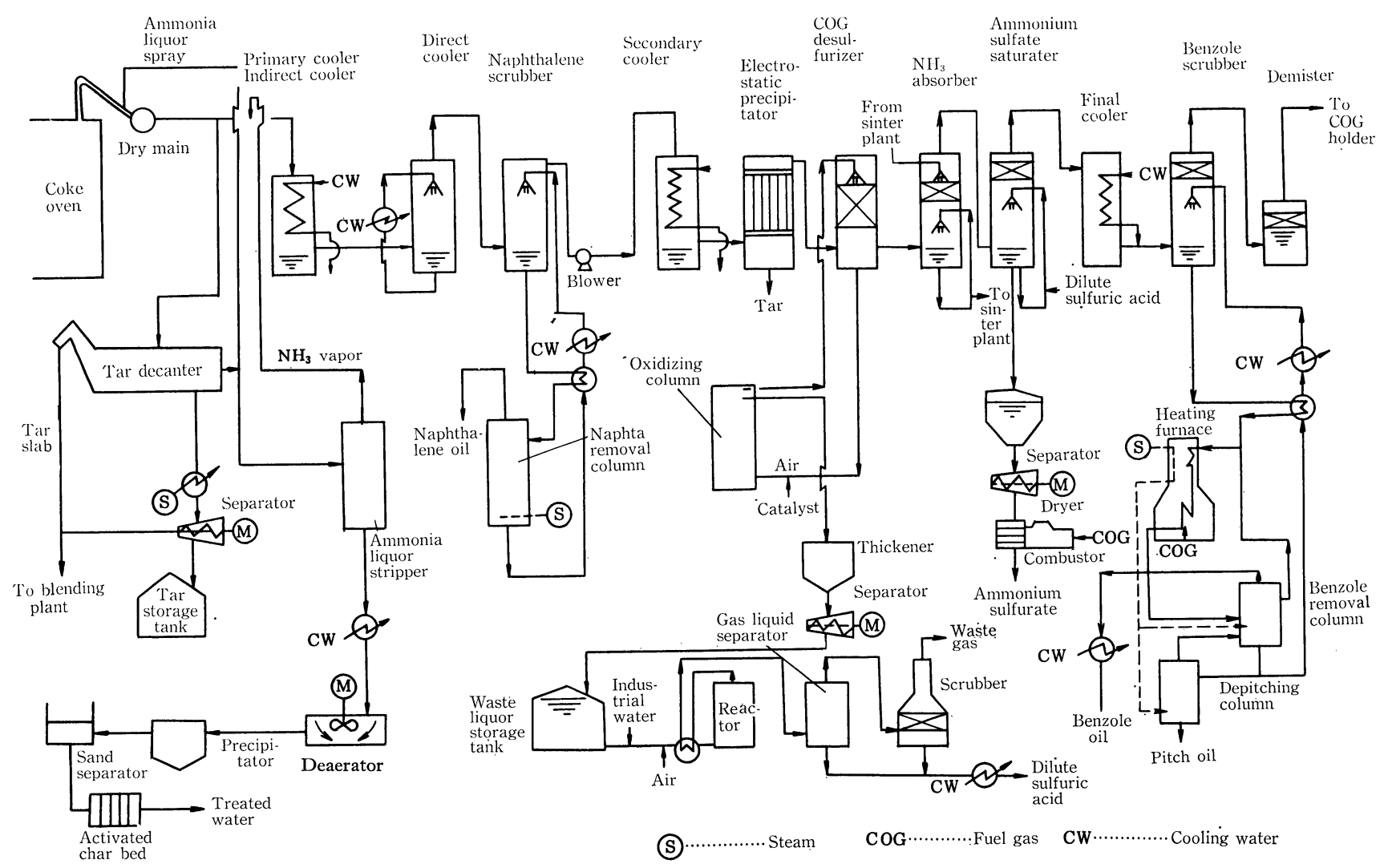

Fig. 3. Process flow of chemical division and examples of popular energy application.

Table 3. STD and TDT rate for chemical division.

\begin{tabular}{c|ccc}
\hline & $\begin{array}{c}\text { GOG } \\
(\mathrm{kcal} / \mathrm{t} \text {-coal })\end{array}$ & $\begin{array}{c}\text { Power } \\
(\mathrm{kWh} / \mathrm{t} \text {-coal })\end{array}$ & $\begin{array}{c}\text { Steam } \\
(\mathrm{kg} / \mathrm{t} \text {-coal })\end{array}$ \\
\hline Rates $(\mathrm{STD}=\mathrm{TGT})$ & $20 \times 10^{3}$ & 25 & 60 \\
\hline
\end{tabular}

Table 4. Operation parameters and correlation formulas.

\begin{tabular}{l|c|c}
\multicolumn{1}{c|}{ Relations } & Correlations & Units \\
\hline Gross yield vs. VM & $-0.85 \mathrm{VM}+99.1$ & $\%$ \\
Lump yield vs. VM & $-0.8 \mathrm{VM}+86.5$ & $\%$ \\
Tar generation vs. VM & $2.8 \mathrm{VM}-39.6$ & $\mathrm{~kg} / \mathrm{t}$-coal \\
GOG generation vs. VM & $5.5 \mathrm{VM}+159$ & $\mathrm{Nm}^{3} / \mathrm{t}$-coal \\
Fuel gas GV vs. GUR & $20 \mathrm{GUR}-100$ & $\mathrm{kcal} / \mathrm{Nm}^{3}$ \\
\hline
\end{tabular}

measures presented in Table 5 .

(2) Determination of STD and TGT Rates

The state-of-arts fuel rate (FR) is $650 \times 10^{3} \mathrm{kcal} / \mathrm{t}$ coal for a CUR of $120 \%$ and VM of $27 \%$. For the Model, it is assumed that the VM remains $27 \%$ but the CUR is lowered to $100 \%$, and that the energy saving measures of Table 6 are all practiced. The results are the STD FR of $576 \times 10^{3} \mathrm{kcal} / \mathrm{t}$-coal for a COG CV (calorific value) of $1000 \mathrm{kcal} / \mathrm{Nm}^{3}$ and a COG generation rate of $312 \mathrm{Nm}^{3} / \mathrm{t}$-coal.

The TGT rates are the same as the STD, except that the steam recovery rate is up by $0.5 \mathrm{t} / \mathrm{t}$-coal thanks to the CDQ line. The state-of-arts values, the STD values and the TGT values are summarized in Table 7 together with values for "New Oven ", which
Table 5. Fuel rate Decrements due to operation changes.

\begin{tabular}{l|l|c}
\hline & Operation variation & $\begin{array}{c}\text { Energy } \\
\text { saved } \\
\left(10^{3} \mathrm{kcal} /\right. \\
\mathrm{t} \text {-coal })\end{array}$ \\
\hline CUR & Increased by $10 \%$ & 16.0 \\
Carburization time & Prolonged by $1 \mathrm{hr}$ & 17.7 \\
Setting time & Shortened by $1 \mathrm{hr}$ & 7.6 \\
Furnace temp. & Held to less than $10^{\circ} \mathrm{C}$ & 1.3 \\
Calorific value & Lowered by $100 \mathrm{kcal} / \mathrm{Nm}^{3}$ & 5.0 \\
Moisture & Lowered by $1 \%$ & 16.8 \\
\hline
\end{tabular}

Table 6. Energy saving measures for coke oven towards STD operation.

\begin{tabular}{c|c|c}
\hline $\begin{array}{c}\text { Energy saving } \\
\text { measures }\end{array}$ & $\begin{array}{c}\text { Present } \\
\text { status }\end{array} \quad$ STD & $\begin{array}{c}\text { Energy saved } \\
\left(10^{3} \mathrm{kcal} / \mathrm{t}-\mathrm{coal}\right)\end{array}$ \\
\hline $\begin{array}{c}\text { Lowering of fuel-to-air } \\
\text { ratio (m) }\end{array}$ & $1.4 \longrightarrow 1.2$ & 23 \\
$\begin{array}{c}\text { Lowering of coke temp. } \\
\left({ }^{\circ} \mathrm{C}\right)^{*}\end{array}$ & $1100 \rightarrow 1010$ & 49 \\
$\begin{array}{c}\text { Lowering of moisture } \\
(\%)\end{array}$ & $9 \longrightarrow 7$ & 18 \\
\hline
\end{tabular}

* Simultaneously COG temp. lowered from 720 to $680^{\circ} \mathrm{C}$.

will be discussed next.

The energy flow for STD operation is shown in Fig. 4, of which the occurrence of various waste heats and their utilization are shown in Fig. 5 and Table 8. 


\section{(3) The Case of New Oven}

Here, what can be done when allowed to start all anew, i.e., if freed of old practices and equipment, is examined to estimate a limit. In anticipation of future coal quality, the low temperature mode of coking practice on a coal of VM $30 \%$ and a low GUR of $80 \%$ are assumed. Then, other operation parameters may be computed out using the formulas of Table 4.

In the FR (fuel rate), energy saving measures of (a) $50 \%$ increase of checker area, which should bring about a $20 \times 10^{3} \mathrm{kcal} / \mathrm{t}$-coal reduction by lowering the

Table 7. Summary of rates and parameters for coke oven.

\begin{tabular}{l|rccc}
\hline & $\begin{array}{c}\text { Present } \\
\text { status }\end{array}$ & STD & TGT & $\begin{array}{c}\text { New } \\
\text { furnace }\end{array}$ \\
\hline Gross yield (\%) & 75.0 & 75.0 & 75.0 & 73.6 \\
Lump yield (\%) & 65.0 & 65.0 & 65.0 & 62.5 \\
GUR (\%) & 120 & 100 & 100 & 80 \\
Goal GV (kcal/kg) & 7700 & 7700 & 7700 & 7700 \\
Tar generation (kg/t) & 36 & 36 & 36 & 44 \\
Grude light oil $(\mathrm{kg} / \mathrm{t})$ & 7.4 & 7.4 & 7.4 & 7.4 \\
FR (103 kcal/t) & 656 & 576 & 576 & 433 \\
PR (kWh/t) & 20 & 20 & 20 & 25 \\
Fuel gas GV (kcal/t) & 1200 & 1000 & 1000 & 1000 \\
COG generation $\left(\mathrm{Nm}{ }^{3} / \mathrm{t}\right)$ & 307 & 312 & 312 & 330 \\
VM (\%) & 27 & 27 & 27 & 30 \\
Steam (kg/t) & 6.7 & 6.7 & 6.7 & 6.7 \\
Compressed air $(\mathrm{Nm} / \mathrm{t})$ & 3.5 & 3.5 & 3.5 & 3.5 \\
Water (kg/t) & 497 & 500 & - & - \\
Recovered steam $(\mathrm{kg} / \mathrm{t})$ & - & - & 500 & 500 \\
\hline
\end{tabular}

waste gas temperature from 190 to $140{ }^{\circ} \mathrm{C}$, and (b) the preheating of the charge coal to $200^{\circ} \mathrm{C}$, which produces $90 \times 10^{3} \mathrm{kcal} / \mathrm{t}$-coal (the heat needed to do this, $110.5 \times 10^{3} \mathrm{kcal} / \mathrm{t}$-coal, is assumed to be recoverable through an appropriate waste heat utilization apparatus), have been taken into account. This gives from the heat balance calculation an FR of $433 \times 10^{3}$ $\mathrm{kcal} / \mathrm{t}$-coal, a figure that is improved even over the TGT by about $25 \%$. On the other hand, as the GUR is lowered, the power rate (PR) is increased by 5 to become $25 \mathrm{kWh} / \mathrm{t}$-coal. The results are shown in Table 7 together with State-of-Arts, STD, and TGT values.

\section{The Ironmaking Sector}

The Ironmaking Sector, which encompasses the Raw Materials, Sintering, BF, and Hot Stove Divisions, is the greatest energy expender in the great energy consumer, the integrated steel works. Therefore, it exerts a great influence on the total energy balance, but because of the absence of generally accepted theory, analysis and determination of technical limits is rather difficult.

Thus, numerical values have been reasonably selected from experiences as shown in Table 2 and Fig. 2. In particular, the coke breeze rate (CBR) was assumed to be $45 \mathrm{~kg} / \mathrm{t}$-sinter and the FR $450 \mathrm{~kg} / \mathrm{t}$-pig (i.e., $\mathrm{FR}=\mathrm{CR}$ (coke rate) $+\mathrm{OR}$ (oil rate) $=415+35$ ) for an SPR (sinter and pellet ratio) of $80+10 \%$ and a TR (tapping rate) of about $1.8 \mathrm{t} / \mathrm{m}^{3} \cdot$ day. Other parameters of operation and the materials flow are as given in Fig. 6, where the chemistries of ore, pellet, lump coke, and sinter are the actual figures averaged over the member firms, while the quantity and the
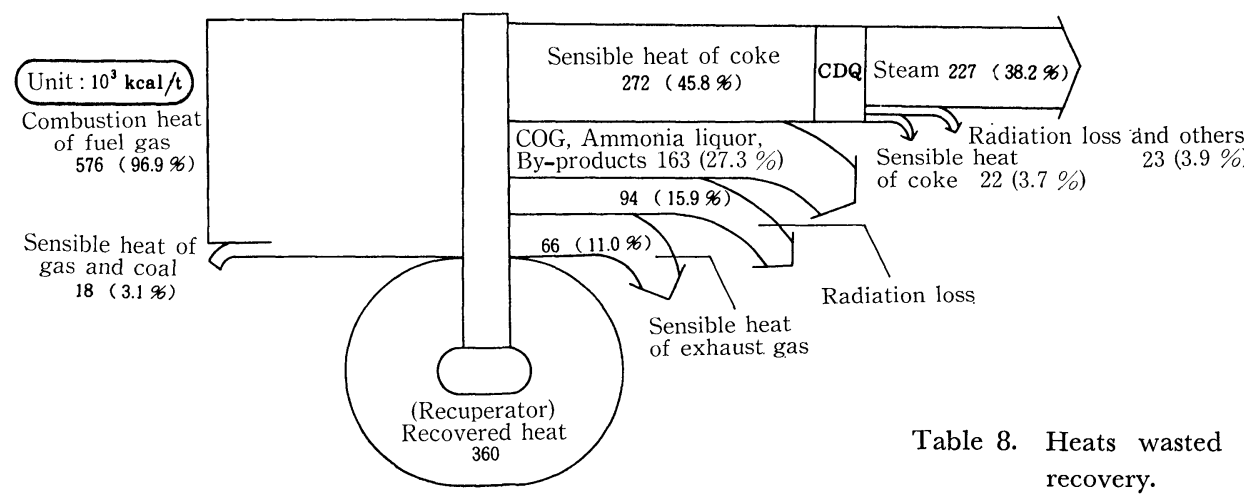

Fig. 4.

Energy flow through coke oven in STD operation.

Table 8. Heats wasted from coke oven and their recovery.

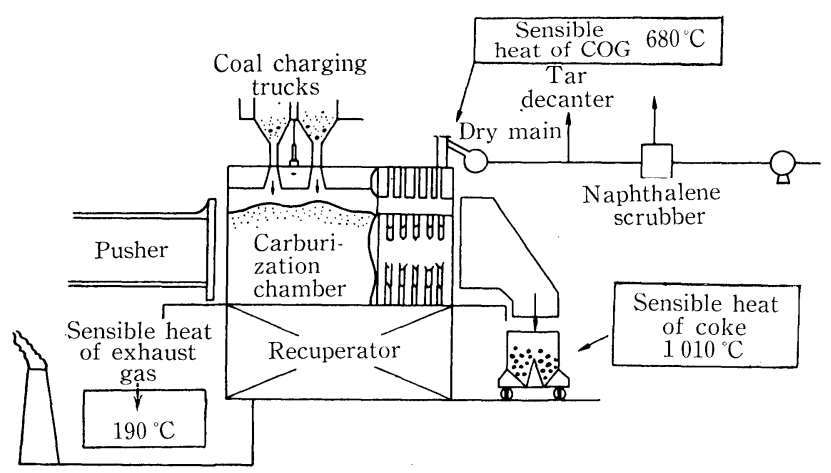

\begin{tabular}{c|c|c|c}
\hline $\begin{array}{c}\text { Sensible } \\
\text { heats }\end{array}$ & $\begin{array}{c}\text { Temp. } \\
\left({ }^{\circ} \mathrm{C}\right)\end{array}$ & $\begin{array}{c}\mathrm{GV} \\
\left(10^{3} \mathrm{kcal} /\right. \\
\mathrm{t} \text {-coal })\end{array}$ & $\begin{array}{c}\text { Method of recovery and } \\
\text { utilization }\end{array}$ \\
\hline Coke & 1010 & 271.9 & $\begin{array}{c}\text { As steam or power by GDQ; } \\
\text { Steam }: 0.5 \mathrm{t}-\mathrm{t} \text { team/t-coke } \\
\text { Power }: 65 \mathrm{kWh} / \mathrm{t} \text {-coal }\end{array}$ \\
\hline COG & 680 & 162.5 & $\begin{array}{c}\text { At the dry main, though no truly } \\
\text { recommendable method is } \\
\text { available ; a } 70 \% \text { recovery } \\
\text { will cover the heat needed } \\
\text { for preheating of coal. }\end{array}$ \\
\hline $\begin{array}{c}\text { Waste } \\
\text { gas }\end{array}$ & 190 & 55.5 & $\begin{array}{l}\text { Temperature is not high enough; } \\
\text { at the lower limit of } 140^{\circ} \mathrm{C}, \\
\text { recoverable heat is no more } \\
\text { than } 150 \times 10^{3} .\end{array}$ \\
\hline
\end{tabular}

Fig. 5. Recoverable exhaust heats of coke oven. 


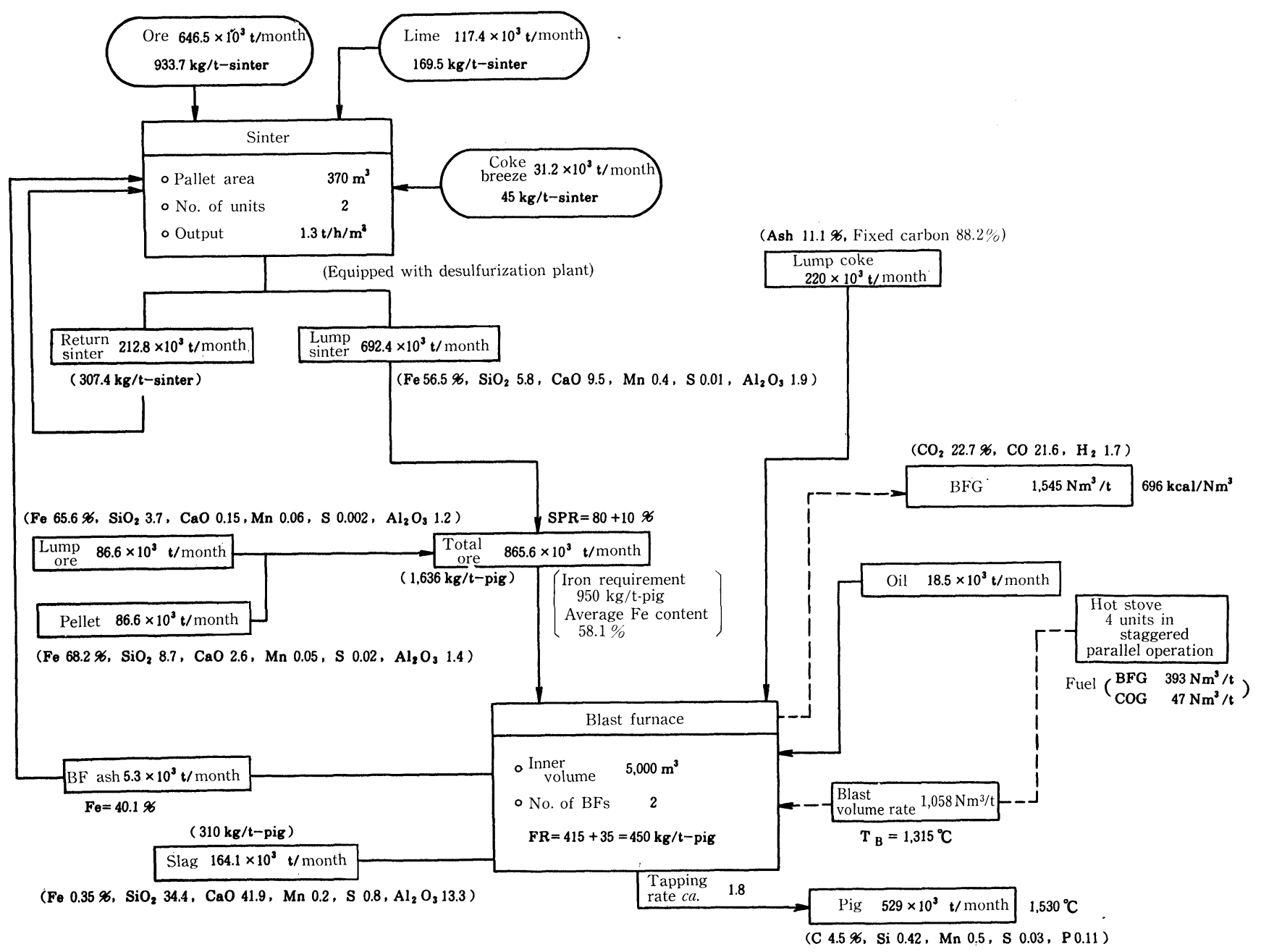

Fig. 6. Operation parameter and material flow of ironmaking sector.

composition of slag as well as those of pig were calculated from the materials balance.

\section{The Raw Materials Division}

Here, only the electric power for materials handling and preparation may be considered. From experiences, the STD PR (power rate) is set at $4 \mathrm{kWh} / \mathrm{t}$ materials handled. Since there appears to be no major energy saving available, the TGT is equated to the STD.

\section{The Sintering Division}

Two DL (Dwight Lloyd) type sintering machines of a pallet area $370 \mathrm{~m}^{2}$, equipped with a desulfurization plant, are provided.

\section{(1) The STD Rates}

The STD rates shown in Table 9 are the averages of actual experiences of member firms having large sintering machines. In the CBR (coke breeze rate), the BFG Ash means the dust caught by the BF dust precipitator to be returned to the sintering machine, and the coke contents in the dust are given. The PR includes that for desulfurization plant, $7 \mathrm{kWh} / \mathrm{t}$-sinter.

The energy flow for STD operation is shown in Fig. 7. The waste gas is set at $2300 \mathrm{Nm}^{3} / \mathrm{t}$-sinter, and the unburnt $\mathrm{CO}$ loss is for $0.4 \% \mathrm{CO}$.

(2) The TGT Rates

The TGT rates, which are shown in Table 9, are
Table 9. The STD and TGT rates for raw materials and sinter divisions.

\begin{tabular}{|c|c|c|c|c|}
\hline Divisions & Rates & Units & STD & TGT \\
\hline $\begin{array}{l}\text { Raw } \\
\text { materials }\end{array}$ & Power & $\begin{array}{l}\mathrm{kWh} / \mathrm{t} \text {-materials } \\
\text { Materials : ore, pel- } \\
\text { lets, coal, lime }\end{array}$ & 4 & 4 \\
\hline Sintering & $\begin{array}{l}\text { Coke breeze } \\
\text { Ignitor COG } \\
\text { Power* }\end{array}$ & $\begin{array}{l}\mathrm{kg} / \mathrm{t} \text {-sinter } \\
(\quad): \mathrm{BF} \text { ash } \\
10^{3} \mathrm{kcal} / \mathrm{t} \text {-sinter } \\
\mathrm{kWh} / \mathrm{t} \text {-sinter }\end{array}$ & $\begin{array}{l}45+ \\
(3.8) \\
21.5 \\
44.0\end{array}$ & $\begin{array}{l}40+ \\
(3.8) \\
16.5 \\
46.0\end{array}$ \\
\hline
\end{tabular}

* Includes the power for desulfurization plant

those that may be achieved over STD by practicing the two energy saving measures of increasing the layer thickness and preheating both the charge and the combustion air with the heat recovered from the sinter cooler.

\section{(i) The Coke Breeze Rate}

The effect of increasing the layer thickness varies according to the scale of the machine and the requirements on the sinter quality, but the best achievements suggest that reduction up to $43 \mathrm{~kg} / \mathrm{t}$-sinter (excluding the BFG ash) is quite possible. As for the preheating sintering practice, in view of the actual results of 3 to 


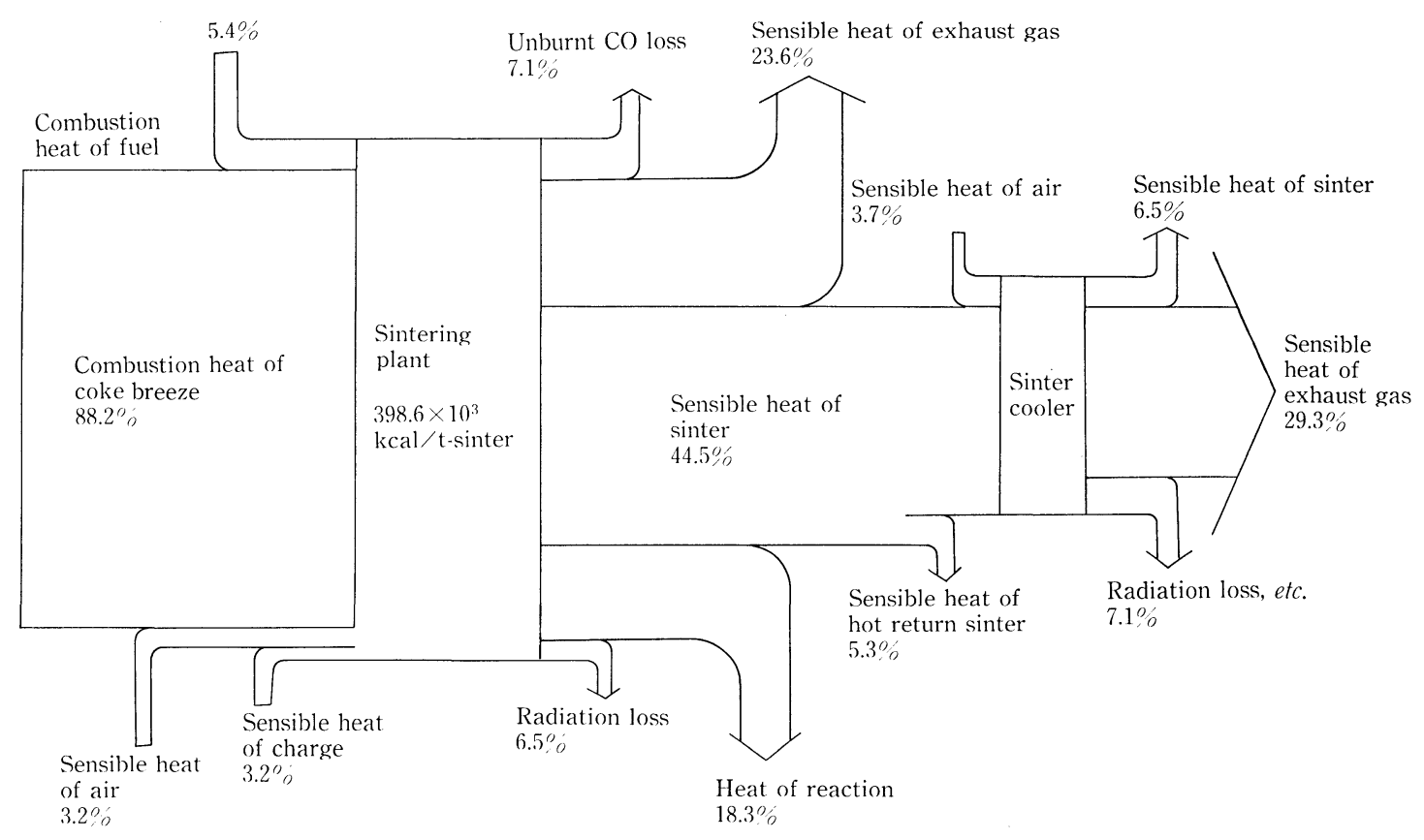

Fig. 7. Energy flow through sinter division in STD operation.

$5 \mathrm{~kg} / \mathrm{t}$-sinter and in consideration of the latent heat of moisture evaporation, its effect has been estimated to be $3 \mathrm{~kg} / \mathrm{t}$-sinter. Those two bring the TGT rate to $40 \mathrm{~kg} / \mathrm{t}$-sinter.

(ii) The Ignitor COG Rate

The STD is related to those rates achieved by ignitors that are practicing pressure control and combustion control. The TGT, $16.5 \times 10^{3} \mathrm{kcal} / \mathrm{t}$-sinter, is the value that should be attained by introducing combustion air preheating, an effect of $5 \times 10^{3} \mathrm{kcal} / \mathrm{t}$ sinter, on top of STD.

(iii) The Power Rate

When those energy saving measures are taken, power consumption is increased by so much as needed for blowing hot gas both for sinter preheating and for combustion air preheating. This hot gas is the air carrying the heat recovered from the sinter cooler, and for an air temperature of $250{ }^{\circ} \mathrm{C}$, warm airs of $270 \mathrm{Nm}^{3} / \mathrm{t}$-sinter for sinter preheating and 62.5 for combustion air preheating are needed to accomplish the economization quoted above. For a pressure loss of $900 \mathrm{mmAq}$ through the waste heat recovery line, the additional blower power requirement is $2 \mathrm{kWh} / \mathrm{t}$ sinter, which determines the TGT.

\section{The STD Rates for Blast Furnace and Hot Stove}

(1) Determination of Operation Parameters and Pig Composition

As mentioned earlier, there are two BFs of $5000 \mathrm{~m}^{3}$ inner volume, tapping pig at a rate of $c a .1 .8 \mathrm{t} / \mathrm{m}^{3} \cdot$ day at $1530^{\circ} \mathrm{C}$. They are each equipped with a TRT (top-pressure recovery turbine) power generation plant and four hot stoves, operating in the staggard/parallel mode to produce hot blast of $1315^{\circ} \mathrm{C}$. A dehumitizer $\left(6 \mathrm{~g} / \mathrm{Nm}^{3}\right)$ and a waste heat recovery apparatus (to heat the combustion air to $200^{\circ} \mathrm{C}$ ) are also provided. The compositions of pig and slag have been computed out by the materials balance assuming the Fe content in the pig to be $950 \mathrm{~kg} / \mathrm{t}$-pig.
Table 10. Operation variations examined.

\begin{tabular}{|c|c|c|}
\hline & Cases to be examined & $\begin{array}{l}\text { Operation } \\
\text { actions* }\end{array}$ \\
\hline $\begin{array}{l}\text { Oil rate }(\mathrm{OR}) \\
\text { decreased }\end{array}$ & $\mathrm{OR}=17 \mathrm{~kg} / \mathrm{t}$ or all coke & Decrease TB \\
\hline $\begin{array}{l}\text { Blast temp. (TB) } \\
\text { changed }\end{array}$ & $\pm 10^{\circ} \mathrm{C}$ & Change OR \\
\hline $\begin{array}{l}\text { Blast moisture }(\mathrm{MB}) \\
\text { increased }\end{array}$ & $\mathrm{MB}=10$ or $15 \mathrm{~g} / \mathrm{Nm}^{3}$ & Decrease OR \\
\hline $\begin{array}{l}\text { Sinter \& pellet rate } \\
\text { (SPR) changed }\end{array}$ & $\mathrm{SPR}=75+15$ or $70+20$ & Constant OR \\
\hline $\begin{array}{c}\text { The "oil-less" } \\
\text { operations }\end{array}$ & $\begin{array}{l}\text { Injection of COG, tar, } \\
\text { or pulverized coal }\end{array}$ & \\
\hline
\end{tabular}

* with the Tuyere Front Temp. (TFT) held constant at $2463^{\circ} \mathrm{C}$

(2) Analysis of BF Operation and Operation Variations

The analysis of STD base BF operation and examination of effects due to the use of oil-alternative fuels, i.e., injection of COG, tar, or pulverized coal for no-oil (or the " oil-less") campaign have been done by conducting the equilibrium calculation for the heat preservation zone (at $1000{ }^{\circ} \mathrm{C}$ ) by means of the Rist diagram method. ${ }^{3-5)}$ Besides those, effects of decreasing the OR, varying the blast temperature and SPR, and increasing the moisture in the blast were considered. The variation conditions are summarized in Table 10.

Other STD's not apparently shown are the shaft efficiency of $96.7 \%$, utilization of in-furnace $\mathrm{CO}$, the $\eta_{\text {co }}, 51.2 \%$, tuyere front temperature $2463{ }^{\circ} \mathrm{C}$ (held constant for all the cases), BFG $\mathrm{CV} 696 \mathrm{kcal} / \mathrm{Nm}^{3}$ $\left(\mathrm{CO}_{2} 22.7 \%, \mathrm{CO} 21.6 \%, \mathrm{H}_{2} 1.7 \%\right.$, balance $\left.\mathrm{N}_{2}\right)$, top pressure $2.15 \mathrm{~kg} / \mathrm{cm}^{2} \mathrm{G}$, and top gas temperature $120{ }^{\circ} \mathrm{C}$. The utilization of $\mathrm{H}_{2}, \eta_{\mathrm{H}_{2}}$, has been assumed to be the same as $\eta_{\mathrm{Co}}$. The results are shown in Table 11, and the corresponding energy flow is illustrated in Fig. 8. 
Table 11. Changes in the rates and parameters due to BF operation variation (STD base).

\begin{tabular}{|c|c|c|c|c|c|c|c|c|c|c|c|c|c|}
\hline \multirow{3}{*}{ 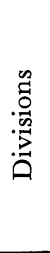 } & \multirow{3}{*}{$\begin{array}{l}\text { Rates and } \\
\text { parameters }\end{array}$} & \multirow{3}{*}{ STD } & \multicolumn{11}{|c|}{ Operation actions taken } \\
\hline & & & \multicolumn{2}{|c|}{$\begin{array}{l}\text { Oil decreased } \\
\text { (TB decreased) }\end{array}$} & \multicolumn{2}{|c|}{$\begin{array}{l}\text { TB varied } \\
\text { (OR varied) }\end{array}$} & \multicolumn{2}{|c|}{$\left|\begin{array}{c}\text { MB increased } \\
(\text { OR decreased })\end{array}\right|$} & \multicolumn{2}{|c|}{$\begin{array}{l}\text { SPR varied } \\
(\mathrm{OR} \text { constant })\end{array}$} & \multicolumn{3}{|c|}{$\begin{array}{c}\text { "Oil-less" operation } \\
\text { (Substitute fuel injection) }\end{array}$} \\
\hline & & & $\begin{array}{l}\mathrm{OR}=17 \\
\mathrm{~kg} / \mathrm{t}-\text { pig }\end{array}$ & $\begin{array}{c}\text { All } \\
\text { coke }\end{array}$ & $\begin{array}{l}\text { TB up } \\
10^{\circ} \mathrm{C}\end{array}$ & $\begin{array}{l}\text { TB down } \\
10^{\circ} \mathrm{C}\end{array}$ & $\begin{array}{l}\mathrm{MB}=10 \\
\mathrm{~g} / \mathrm{Nm}^{3}\end{array}$ & $\begin{array}{c}\mathrm{MB}=15 \\
\mathrm{~g} / \mathrm{Nm}^{3}\end{array}$ & $\begin{array}{l}\mathrm{SPR}= \\
75 \\
+15 \%\end{array}$ & $\begin{array}{c}\mathrm{SPR}= \\
70 \\
+20 \%\end{array}$ & $\begin{array}{c}\text { COG } \\
50.67 \\
\mathrm{Nm}^{3} / \mathrm{t}-\text { pig }\end{array}$ & $\begin{array}{c}\text { Tar } \\
27.5 \mathrm{~kg} / \\
\mathrm{g} \text { t-pig }\end{array}$ & $\begin{array}{l}\text { Coal }^{* 1} \\
55.1 \mathrm{~kg}\end{array}$ \\
\hline 1 & $\mathrm{PR}(\mathrm{kWh} / \mathrm{t})$ & 4 & 4 & 4 & 4 & 4 & 4 & 4 & 4 & 4 & 4 & 4 & 4 \\
\hline \multirow{3}{*}{2} & CBR (kg/t-sinter) & $45+3.8$ & $45+3.8$ & $45+3.8$ & $45+3.8$ & $45+3.8$ & $45+3.8$ & $45+3.8$ & $45+3.8$ & $45+3.8$ & $45+3.8$ & $45+3.3$ & $45+3.8$ \\
\hline & $\begin{array}{l}\text { Igniter COG } \\
\left(10^{3} \mathrm{kcal} / \mathrm{t}-\sin t e r\right)\end{array}$ & 21.5 & 21.5 & 21.5 & 21.5 & 21.5 & 21.5 & 21.5 & 21.5 & 21.5 & 21.5 & 21.5 & 21.5 \\
\hline & PR (kWh/t-sinter) & 44.0 & 44.0 & 44.0 & 44.0 & 44.0 & 44.0 & 44.0 & 47.2 & 50.9 & 44.0 & 44.0 & 44.0 \\
\hline \multirow{14}{*}{3} & FR (kg/t-pig) & 450.0 & 460.0 & 472.0 & 449.8 & 450.2 & 450.9 & 452.2 & 452.0 & 455.0 & 458.2 & 453.3 & 457.9 \\
\hline & CR (kg/t-pig) & 415.0 & 443.0 & 472.0 & 417.0 & 417.0 & 421.3 & 429.2 & 417.0 & 420.0 & 433.3 & 425.8 & 402.8 \\
\hline & OR etc. (kg/t-pig) & 35.0 & 17.0 & 0 & 36.8 & 33.2 & 29.6 & 23.1 & 35.0 & 35.0 & 24.9 & 27.5 & 55.1 \\
\hline & $\begin{array}{l}\text { Blast volume rate } \\
\left(\mathrm{Nm}^{3} / \mathrm{t}-\mathrm{pig}\right)\end{array}$ & 1058 & 1095 & 1131 & 1059 & 1056 & 1049 & 1038 & 1065 & 1072 & 1044 & 1056 & 1043 \\
\hline & $\mathrm{BFG}\left(\mathrm{Nm}^{3} / \mathrm{t}\right.$-pig$)$ & 1545 & 1585 & 1606 & 1547 & 1543 & 1538 & 1531 & 1555 & 1564 & 1559 & 1505 & 1516 \\
\hline & BFG GV (kcal/ $\left./ \mathrm{Nm}^{3}\right)$ & 696 & 682 & $676 * 2$ & 695 & 696 & 698 & 701 & 699 & 701 & 705 & 686 & 694 \\
\hline & $\eta_{\mathrm{Co}}(\%)$ & 51.2 & 51.0 & 50.7 & 51.2 & 51.2 & 51.2 & 51.2 & 50.9 & 50.6 & 51.1 & 51.4 & 51.2 \\
\hline & Blast temp. $\left({ }^{\circ} \mathrm{C}\right)$ & 1315 & 1213 & 1120 & 1325 & 1305 & 1315 & 1315 & 1315 & 1315 & 1315 & 1315 & 1315 \\
\hline & $\begin{array}{l}\text { Blast moisture } \\
\quad\left(\mathrm{g} / \mathrm{Nm}^{3}\right)\end{array}$ & 6 & 6 & 6 & 6 & 10 & 15 & 6 & 6 & 6 & 6 & 6 & 6 \\
\hline & $\mathrm{TFT}^{* 3}\left({ }^{\circ} \mathrm{C}\right)$ & 2463 & 2463 & 2462 & 2463 & 2463 & 2463 & 2463 & 2463 & 2464 & 2460 & 2461 & 2463 \\
\hline & $\begin{array}{l}\text { Top pressure } \\
\left(\mathrm{kg} / \mathrm{cm}^{2}\right)\end{array}$ & 2.15 & 2.15 & 2.15 & 2.15 & 2.15 & 2.15 & 2.15 & 2.15 & 2.15 & 2.15 & 2.15 & 2.15 \\
\hline & Top gas temp. $\left({ }^{\circ} \mathrm{C}\right)$ & 120 & 120 & 120 & 120 & 120 & 120 & 120 & 120 & 120 & 120 & 120 & 120 \\
\hline & Slag rate $(\mathrm{kg} / \mathrm{t}-\mathrm{pig})$ & 310 & 314 & 316 & 310 & 311 & 311 & 312 & 300 & 290 & 310 & 310 & 310 \\
\hline & TRT PS (kWh/t-pig) & 35.6 & 36.6 & 37.0 & 35.7 & 35.6 & 35.5 & 35.3 & 35.9 & 36.1 & 35.9 & 35.9 & 35.0 \\
\hline \multirow{3}{*}{4} & $\begin{array}{l}\text { BFG rate } \\
\left(\mathrm{Nm}^{3} / \mathrm{t}-\text { pig }\right)\end{array}$ & 393 & 460 & 529 & 387 & 397 & 389 & 390 & 396 & 400 & 386 & 393 & 389 \\
\hline & $\begin{array}{l}\text { COG rate } \\
\left(\mathrm{Nm}^{3} / \mathrm{t}-\mathrm{pig}\right)\end{array}$ & 47 & 32 & 17 & 49 & 45 & 46 & 46 & 47 & 47 & 46 & 47 & 47 \\
\hline & $\mathrm{M} \underset{\left(\mathrm{kcal} / \mathrm{Nm}^{3}\right)}{\operatorname{gas} \mathrm{GV}}$ & 1110 & 938 & 800 & 1129 & 1091 & 1111 & 1111 & 1108 & 1108 & 1114 & 1105 & 1113 \\
\hline
\end{tabular}

*1 Pulverized coal $55.1 \mathrm{~kg} / \mathrm{t}$-pig

*2 The decrease of BFG GV is due to assumption of $\eta_{\mathrm{H}_{2}}=\eta_{\mathrm{CO}}, \quad$ Division : 1 Raw materials; 2 Sinter; 3 BF ; 4 Hot stove which applies to other cases also.

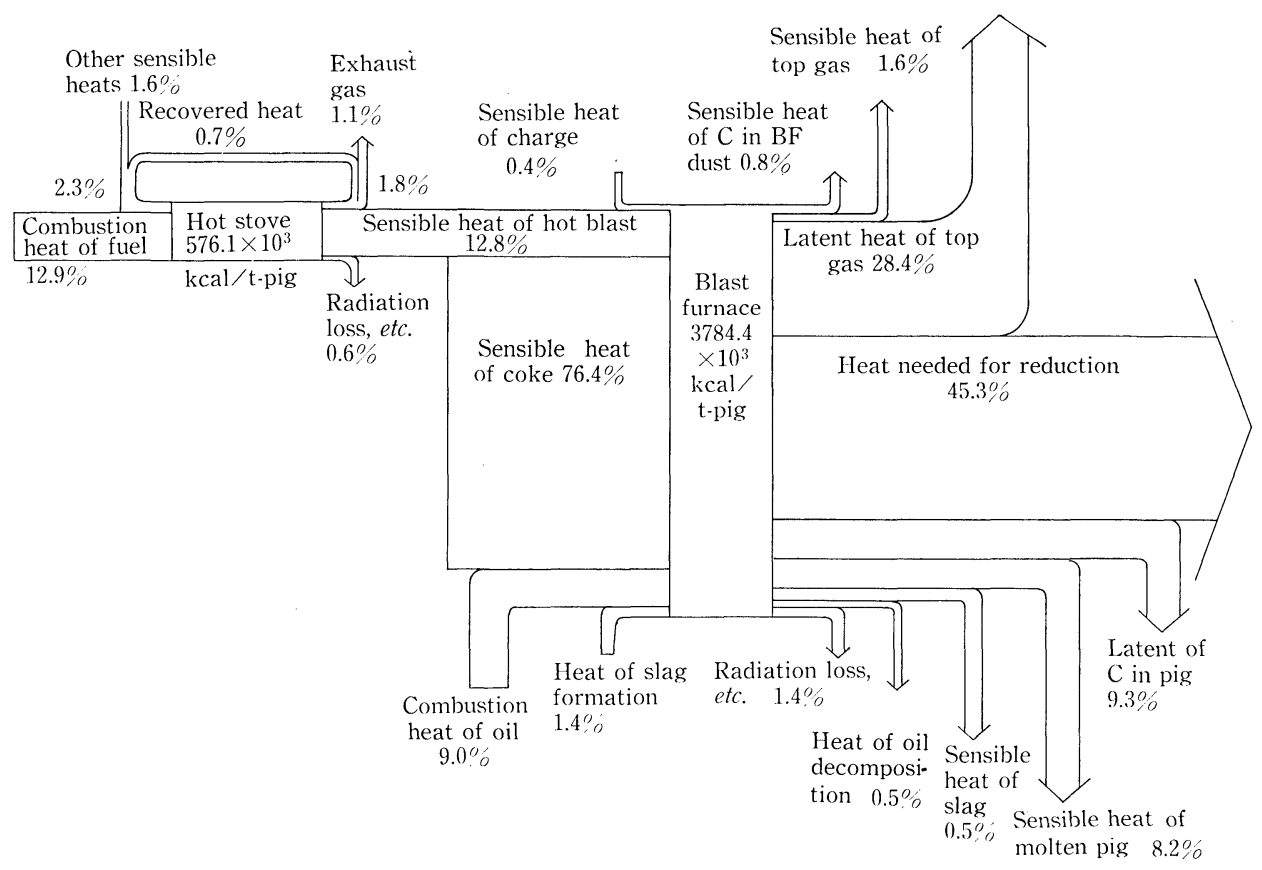

Fig. 8.

Energy flow through blast furnace in STD operation. 
Nextly, the effects of those operation variations and the alternative fuel campaign on the total energy balance of the entire ironmaking sector, involving all the coke oven, raw materials, sintering, BF, and hot stove divisions, were computed out. Those are summarized in Table 12 (see p. 872 3) and Fig. 9. It will be seen among others that the all-coke operation will bring about an energy increase of $72 \times 10^{3} \mathrm{kcal} / \mathrm{t}$-pig over the STD, and that a change of SPR from the STD $80+10 \%$ to $70+20$ will result in a decrease by $60 \times 10^{3} \mathrm{kcal} / \mathrm{t}$-pig from STD, though this is due to not assigning any energy value to the pellet.

\section{The TGT Rates of Blast Furnace and Hot Stove}

(1) Energy Saving Measures for BF and the TGT Rates

(i) Lowering of Fuel Rate

Proper control of burden distribution is known to help improve the gas utilization. As quantitative appreciation of this effect is difficult, however, the TGT was set on an assumption that the shaft efficiency could be raised to $98 \%$ from the STD of $96.7 \%$. Other TGT rates were computed out on this as shown in Table 13, where an ideal case of shaft efficiency of $100 \%$ is also presented.

(ii) Equalizing-and-Relieving Recovery of Top Pressure

By this practice, the BFG recovery is improved by $0.6 \%$.

\section{(iii) The Dry Dust Collector}

The use of a dry dust collector in place of currently popular wet precipitator will entail a $600 \mathrm{mmAq}$ decrease in the pressure loss to TRT and a raise of TRT inlet temperature to 110 from $50^{\circ} \mathrm{G}$. Those two combined will increase the TRT power output from $35.6 \mathrm{kWh} / \mathrm{t}$-pig to 42.9 .

(iv) Heat Recovery from BF Slag

The recovery rate has been set at $60 \%$. The heat recovered may be utilized either as process steam or electric power depending on the current energy situation of the works.

\section{(2) The Hot Stove}

The STD thermal efficiency of $80 \%$ is the average of the actual experiences. Further, by taking measures to prevent localization of gas flow in the hot oven, yet another $2 \%$ gain can be expected. This gives the TGT. The STD and the TGT rates are shown in Table 14, where the following two formulas were used to calculate the thermal efficiency, $\eta_{\mathrm{HS}}$ :

$$
\begin{aligned}
\eta_{\mathrm{HS}}= & (\text { Wind sensible heat }) /[\text { (Fuel latent heat }) \\
& +(\text { Fuel sensible heat })+(\text { Preheated air } \\
& \text { sensible heat })+(\text { Cold wind sensible heat })]
\end{aligned}
$$

Dome temperature $=(0.95 \times$ Flame

$$
\text { temperature) }-150^{\circ} \mathrm{C}
$$

(3) No-oil Operation Variations for TGT Rates

To examine the current no-oil operation and future

\begin{tabular}{|c|c|c|c|c|}
\hline \multirow[t]{2}{*}{$\begin{array}{l}\text { Operational } \\
\text { variations }\end{array}$} & \multirow[b]{2}{*}{ STD } & \multirow[b]{2}{*}{$\begin{array}{l}\text { Varied } \\
\text { to }\end{array}$} & \multirow{2}{*}{$\begin{array}{c}\mathrm{FR} \\
(\mathrm{kg} / \\
\mathrm{t}-\mathrm{pig})\end{array}$} & $\begin{array}{l}\text { Ironmaking total energy } \\
\qquad\left[10^{3} \mathrm{kcal} / \mathrm{t}-\mathrm{pig}\right]\end{array}$ \\
\hline & & & & $\begin{array}{llll}3700 & 3750 & 3800 & 385 \\
\end{array}$ \\
\hline STD & - & - & $\begin{array}{l}450 \\
\text { (OR 35) }\end{array}$ & \\
\hline $\mid \begin{array}{c}\mathrm{OR} \\
{[\mathrm{kg} / \mathrm{t}-\mathrm{pig})}\end{array}$ & $\begin{array}{l}35 \\
11\end{array}$ & $\begin{array}{c}17 \\
0\end{array}$ & $\begin{array}{c}460 \\
\text { (OR 17) } \\
472\end{array}$ & \\
\hline $\begin{array}{l}\text { Blast } \\
\text { temp. } \\
\left({ }^{\circ} \mathrm{C}\right)\end{array}$ & 1315 & $\begin{array}{l}1325 \\
1305\end{array}$ & \begin{tabular}{|c|}
449.8 \\
(OR 36.8$)$ \\
450.2 \\
OR 33.2$)$ \\
\end{tabular} & \\
\hline $\begin{array}{c}\text { Blast } \\
\text { moisture } \\
\left(\mathrm{g} / \mathrm{Nm}^{3}\right) \\
\end{array}$ & 6 & $\begin{array}{l}10 \\
15\end{array}$ & \begin{tabular}{|c|}
450.9 \\
(OR 29.6) \\
452.2 \\
(OR 23.1) \\
\end{tabular} & \\
\hline $\begin{array}{ccc}S & P & R \\
(\%) & R\end{array}$ & $80+10$ & $\begin{array}{l}75+15 \\
70+20\end{array}$ & \begin{tabular}{|c|}
452 \\
(OR 35) \\
455 \\
(OR 35) \\
\end{tabular} & \\
\hline $\begin{array}{c}\text { No oil } \\
\text { /I } \\
\text { /I }\end{array}$ & $\begin{array}{c}\text { OR35 } \\
/ 1 \\
1 /\end{array}$ & $\begin{array}{c}\mathrm{COG} \\
\text { Tar } \\
\text { P'd coal }\end{array}$ & \begin{tabular}{|r|}
458.2 \\
$(24.9)$ \\
453.3 \\
$(27.5)$ \\
457.9 \\
$(551)$ \\
\end{tabular} & \\
\hline & $\begin{array}{r}\text { *COG } \\
\text { Tar } \mathrm{F} \\
\text { Pulveri } \\
\text { Ironme } \\
\text { oven } \\
\text { ated } \\
\text { powe }\end{array}$ & $\begin{array}{l}\mathrm{H}_{l}=4 \\
\mathrm{H}_{l}=82 \mathrm{C} \\
\text { ized coa } \\
\text { aking } \mathrm{t} \\
+ \text { Sinte } \\
- \text { Powe } \\
\text { er for } \mathrm{b}\end{array}$ & $\begin{array}{l}511 \mathrm{kca} \\
0 \mathrm{kcal} / \\
\mathrm{H}_{l}=7 \\
\text { otal er } \\
\mathrm{r}+\mathrm{Hot} \\
\text { er gen }\end{array}$ & $\begin{array}{l}1 / \mathrm{Nm}^{3} \\
211 \mathrm{kcal} / \mathrm{kg} \text { (Ash } 8 \% \text { ) } \\
\mathrm{kg} \\
\text { ergy = Raw materials + Coke } \\
\text { stove }+\mathrm{BF}-\mathrm{BFG} \text { (as gener- } \\
\text { rated by TRT (excluding } \\
\text { wer) }\end{array}$ \\
\hline
\end{tabular}
gas balance, TGT rates and figures were calculated. Those are shown in Table 15 in comparison with the STD values.
Fig. 9. Changes in ironmaking total energy according to variations of operation.

Table 13. Rates and parameters for BF TGT and ideal operations.

\begin{tabular}{l|cc}
\hline & TGT & Ideal* \\
\hline Shaft efficiency (\%) & 98.0 & 100.0 \\
FR (=GR+OR) $(\mathrm{kg} / \mathrm{t}-\mathrm{pig})$ & $446(=411+35)$ & $440(=405+35)$ \\
Blast temp. $\left({ }^{\circ} \mathrm{C}\right)$ & 1315 & 1315 \\
Blast moisture $\left(\mathrm{g} / \mathrm{Nm}^{3}\right)$ & 6 & 6 \\
Blast volume rate $\left(\mathrm{Nm}^{3} / \mathrm{t}-\right.$ & 1050 & 1037 \\
pig) & 1518 & 1511 \\
BFG $\left(\mathrm{Nm}^{3} / \mathrm{t}-\mathrm{pig}\right)$ & 52.1 & 53.6 \\
$\eta_{\mathrm{CO}}(\%)$ & 685 & 662 \\
BFG GV (kcal/Nm & \\
\hline
\end{tabular}

* Calculated according to Rist ${ }^{3)}$

Table 14. Rates and parameters for STD and TGT hot stove operations.

\begin{tabular}{l|cc}
\hline & $\begin{array}{c}\text { STD } \\
\eta_{\mathrm{HS}}=80 \%\end{array}$ & $\begin{array}{c}\text { TGT } \\
\eta_{\mathrm{HS}}=82 \%\end{array}$ \\
\hline BFG $\left(696 \mathrm{kcal} / \mathrm{Nm}^{3}\right)\left(\mathrm{Nm}^{3} / \mathrm{t}\right)$ & 393 & 382 \\
COG $\left(4600 \mathrm{kcal} / \mathrm{Nm}^{3}\right)\left(\mathrm{Nm}^{3} / \mathrm{t}\right)$ & 47 & 45.6 \\
M gas $\left(\mathrm{kcal} / \mathrm{Nm}^{3}\right)$ & 1110 & 1110 \\
Heat rate $\left(10^{3} \mathrm{kcal} / \mathrm{t}-\mathrm{pig}\right)$ & 490 & 475.6 \\
\hline
\end{tabular}

\section{The Steelmaking Sector}

The energy consumed in the Steelmaking Sector is no more than about $4 \%$ of the total. Seemingly this is quite small, but when the latent and sensible heats of $\mathrm{C}$ and $\mathrm{Si}$ and others that the hot metal brings in amount to an equivalent of $c a .15 \%$. Besides, there is the energy, ca. $6 \%$ equivalent, that is needed to prepare the auxiliary raw materials. Therefore, in the Steelmaking Sector, the points of energy saving should be placed, aside from the obvious and straightforward 
Table 12. Total energy for ironmaking.

\begin{tabular}{|c|c|c|c|c|c|c|c|c|}
\hline \multirow{2}{*}{ Plants } & \multirow{2}{*}{ STD } & \multicolumn{2}{|c|}{ Oil injection } & \multicolumn{2}{|c|}{ Blast temp. } & \multicolumn{2}{|c|}{ Blast moisture } & \multirow{2}{*}{$\begin{array}{r}\text { SPR } \\
75+15 \%\end{array}$} \\
\hline & & $17 \mathrm{~kg} / \mathrm{t}$ & All coke & $1325^{\circ} \mathrm{C}$ & $1305^{\circ} \mathrm{C}$ & $10 \mathrm{~g} / \mathrm{Nm}^{3}$ & $15 \mathrm{~g} / \mathrm{Nm}^{3}$ & \\
\hline Coke oven & 368.8 & 402.8 & 442.2 & 364.7 & 369.4 & 375.3 & 385.5 & 369.4 \\
\hline Raw materials & 19.1 & 19.1 & 19.1 & 19.1 & 19.1 & 19.1 & 19.1 & 19.1 \\
\hline Sintering & 629.2 & 629.2 & 629.2 & 629.2 & 629.2 & 629.2 & 629.2 & 629.2 \\
\hline Blast furnace & 2248.6 & 2264.7 & 2300.1 & 2251.9 & 2246.8 & 2243.0 & 2235.7 & 2250.8 \\
\hline Coke & 2988.0 & 3189.6 & 3398.4 & 2973.6 & 3002.4 & 3033.4 & 3089.5 & 3002.4 \\
\hline Oil, etc. & 345.1 & 167.6 & 0 & 362.8 & 327.4 & 291.9 & 227.8 & 345.1 \\
\hline BFG & -1075.3 & -1081.0 & -1085.7 & -1075.2 & -1073.9 & -1073.5 & -1073.2 & -1086.9 \\
\hline TRT power & -87.3 & -89.6 & -90.7 & -87.4 & -87.2 & -86.9 & -86.5 & -87.9 \\
\hline Power & 73.5 & 73.5 & 73.5 & 73.5 & 73.5 & 73.5 & 73.5 & 73.5 \\
\hline Hot stove & 493.6 & 465.1 & 440.3 & 498.3 & 487.3 & 487.0 & 488.9 & 496.9 \\
\hline $\mathrm{BFG}$ & 273.5 & 313.7 & 357.6 & 269.0 & 276.3 & 271.5 & 273.4 & 276.8 \\
\hline COG & 215.2 & 146.5 & 77.8 & 224.4 & 206.1 & 210.6 & 210.6 & 215.2 \\
\hline Power & 4.9 & 4.9 & 4.9 & 4.9 & 4.9 & 4.9 & 4.9 & 4.9 \\
\hline Grand total & 3759.3 & 3780.9 & 3830.9 & 3763.2 & 3751.8 & 3753.6 & 3758.4 & 3722.7 \\
\hline
\end{tabular}

Notes: 1. Figures include the power for blower and energy for dehumidizer.

2. A $90 \mathrm{kWh} / \mathrm{t}$-pulverized coal is

Table 15. Changes in the rates and parameters due to BF operation variation (TGT base).

\begin{tabular}{|c|c|c|c|c|c|c|c|c|c|c|}
\hline \multirow{3}{*}{ Operation actions } & \multirow{3}{*}{ STD } & \multirow{3}{*}{ TGT } & \multirow{2}{*}{\multicolumn{2}{|c|}{ All coke }} & \multicolumn{6}{|c|}{ Substitute fuel injection } \\
\hline & & & & & \multicolumn{2}{|c|}{ COG } & \multicolumn{2}{|c|}{ Tar } & \multicolumn{2}{|c|}{ Pulverized coal } \\
\hline & & & STD & TGT & STD & TGT & STD & TGT & STD & TGT \\
\hline Shaft efficiency (\%) & 96.7 & 98.0 & 96.7 & 98.0 & 96.7 & 98.0 & 96.7 & 98.0 & 96.7 & 98.0 \\
\hline Hot stove efficiency (\%) & 80.0 & 82.0 & 80.0 & 82.0 & 80.0 & 82.0 & 80.0 & 82.0 & 80.0 & 82.0 \\
\hline Fuel rate $(\mathrm{kg} / \mathrm{t}-\mathrm{pig})$ & 450.0 & 446.0 & 472.0 & 468.2 & 458.2 & 454.0 & 453.3 & 449.4 & 457.9 & 454.0 \\
\hline Coke rate $(\mathrm{kg} / \mathrm{t}$-pig) & 415.0 & 411.0 & 472.0 & 468.2 & 433.3 & 429.1 & 425.8 & 421.9 & 402.8 & 399.4 \\
\hline Oil (etc.) rate $(\mathrm{kg} / \mathrm{t}$-pig) & 35.0 & 35.0 & 0 & 0 & 24.9 & 24.9 & 27.5 & 27.5 & 55.1 & 54.6 \\
\hline Blast volume rate $\left(\mathrm{Nm}^{3} / \mathrm{t}\right.$-pig) & 1058 & 1050 & 1131 & 1121 & 1044 & 1036 & 1056 & 1047 & 1043 & 1035 \\
\hline BFG $\left(\mathrm{Nm}^{3} / \mathrm{t}\right.$-pig $)$ & 1545 & 1518 & 1606 & 1591 & 1559 & 1545 & 1505 & 1499 & 1516 & 1503 \\
\hline $\mathrm{BFG} \mathrm{CV}\left(\mathrm{kcal} / \mathrm{Nm}^{3}\right)$ & 696 & 685 & $676 *$ & $661 *$ & 705 & 693 & 686 & 671 & 694 & 677 \\
\hline$\eta_{\mathrm{CO}}(\%)$ & 51.2 & 52.1 & 50.7 & 51.6 & 51.1 & 52.0 & 51.4 & 52.4 & 51.2 & 52.8 \\
\hline Blast temp. $\left({ }^{\circ} \mathrm{C}\right)$ & 1315 & 1315 & 1120 & 1120 & 1315 & 1315 & 1315 & 1315 & 1315 & 1315 \\
\hline Blast moisture $\left(\mathrm{g} / \mathrm{Nm}^{3}\right)$ & 6 & 6 & 6 & 6 & 6 & 6 & 6 & 6 & 6 & 6 \\
\hline Tuyere front temp. $\left({ }^{\circ} \mathrm{C}\right)$ & 2463 & 2463 & 2462 & 2462 & 2460 & 2450 & 2461 & 2460 & 2463 & 2463 \\
\hline Top pressure $\left(\mathrm{kg} / \mathrm{cm}^{2}\right)$ & 2.15 & 2.15 & 2.15 & 2.15 & 2.15 & 2.15 & 2.15 & 2.15 & 2.15 & 2.15 \\
\hline Top gas temp. $\left({ }^{\circ} \mathrm{C}\right)$ & 120 & 120 & 120 & 120 & 120 & 120 & 120 & 120 & 120 & 120 \\
\hline Slag rate $(\mathrm{kg} / \mathrm{t}-\mathrm{pig})$ & 310 & 310 & 316 & 313 & 310 & 310 & 310 & 310 & 310 & 310 \\
\hline TRT power $(\mathrm{kWh} / \mathrm{t}-$ pig) & 35.6 & 42.7 & 37.0 & 44.8 & 35.9 & 43.5 & 34.9 & 42.2 & 35.0 & 42.3 \\
\hline $\mathrm{BFG}$ rate $\left(\mathrm{Nm}^{3} / \mathrm{t}\right.$-pig $)$ & 393 & 375 & 529 & 499 & 386 & 366 & 393 & 371 & 389 & 364 \\
\hline COG rate $\left(\mathrm{Nm}^{3} /\right.$ t-pig $)$ & 47.0 & 46.7 & 17.0 & 19.8 & 46.0 & 46.0 & 47.0 & 48.1 & 47.0 & 47.4 \\
\hline $\mathrm{M}$ gas $\mathrm{CV}\left(\mathrm{kcal} / \mathrm{Nm}^{3}\right)$ & 1110 & 1116 & 800 & 811 & 1114 & 1129 & 1105 & 1122 & 1113 & 1129 \\
\hline
\end{tabular}

* The decrease of BFG CV is due to the assumption of $\eta_{\mathrm{H}_{2}}=\eta_{\mathrm{CO}}$, which applies to other cases also.

cutting down on the direct energy consumption, on how to reduce the auxiliary materials requirement as well as how to efficiently recover the waste energy of converter refining process and the sensible heats of the products.

\section{The STD and TGT Rates}

The entire rate system of the Steelmaking Sector is examined by five divisions of Lime Calcination, BOF, Ingotmaking, Degassing, Continuous Casting (CG) of Slabs and Blooms, and Grooming* of Continuously

* Seisei, or to finely prepare. "Grooming" is here proposed for conventional " finishing ", for, born out of the QG (quality control) movement, this word denotes activities that are more comprehensive than mere finishing. For example, in the CG grooming line, mechanical and metallographic tests are conducted often as a matter of course. 
Unit : $10^{3} \mathrm{kcal} / \mathrm{t}-\mathrm{pig}$

\begin{tabular}{r|rrr} 
varied & \multicolumn{3}{|c}{ Substitute fuel injection } \\
\hline $70+20 \%$ & \multicolumn{1}{|c}{ GOG } & Tar & Pulverized coal \\
\hline 373.5 & 390.6 & 381.2 & 352.6 \\
19.1 & 19.1 & 19.1 & 19.1 \\
629.2 & 629.2 & 629.2 & 629.2 \\
\hline 2262.4 & 2242.7 & 2252.0 & 2254.5 \\
\hline 3024.0 & 3119.8 & 3065.8 & 2900.2 \\
345.1 & 232.0 & 225.5 & 401.0 \\
-1096.4 & -1099.1 & -1032.4 & -1051.3 \\
-88.4 & -88.1 & -85.0 & -85.7 \\
73.5 & 73.5 & 73.5 & 73.5 \\
\hline 500.5 & 487.6 & 489.7 & 490.2 \\
\hline 280.4 & 272.1 & 269.6 & 270.0 \\
215.2 & 210.6 & 215.2 & 215.3 \\
4.9 & 4.9 & 4.9 & 4.9 \\
\hline 3699.7 & 3769.2 & 3771.2 & 3745.4 \\
\hline
\end{tabular}

included in the Pulverized coal injection.
Cast Slabs and Blooms. The STD and the TGT rates of those divisions are shown in Table 16 together with the energy saving measures adopted.

The lime calcination furnace is the rotary kiln, which is the most popular among the member firms, whose FR is given as $963 \times 10^{3} \mathrm{kcal} / \mathrm{t}-\mathrm{CaO}$ from the actual achievements. As this figure is close enough to the theoretical value of $800 \mathrm{kcal}$ for the $\mathrm{CaCO}_{3} \rightarrow$ $\mathrm{CaO}+\mathrm{CO}_{2}$ reaction, the TGT is equated to the STD.

The BOF is of the top blowing type with its OG (off gas) energy to be recovered by a boiler. From the STD oxygen rate of $45 \mathrm{Nm}^{3} / \mathrm{t}, 1.5 \mathrm{Nm}^{3} / \mathrm{t}$ is expected to be curtailed by adding more iron ore. This should become possible by preventing the drop of hot metal temperature by $50{ }^{\circ} \mathrm{C}$ (from 180 to $130{ }^{\circ} \mathrm{C}$ for the charging temperature of $1350{ }^{\circ} \mathrm{C}$ ). Another $0.5 \mathrm{Nm}^{3} / \mathrm{t}$ should be taken out by making the blow pattern even more appropriate. Thus, the TGT is set at $43 \mathrm{Nm}^{3} /$ t.

The STD PR is $24 \mathrm{kWh} / \mathrm{t}$, from which $3.5 \mathrm{kWh} / \mathrm{t}$ should be curtailable by practicing the revolution control on both the induced draft fan and the dust collector blower, and another $0.5 \mathrm{kWh} / \mathrm{t}$ by intensifying the saving of power for cooling water pumps and general illumination.

The STD for LDG recovery is $100 \mathrm{Nm}^{3} / \mathrm{t}$ (an ef-

Table 16. The STD and the TGT rates for steelmaking sector.

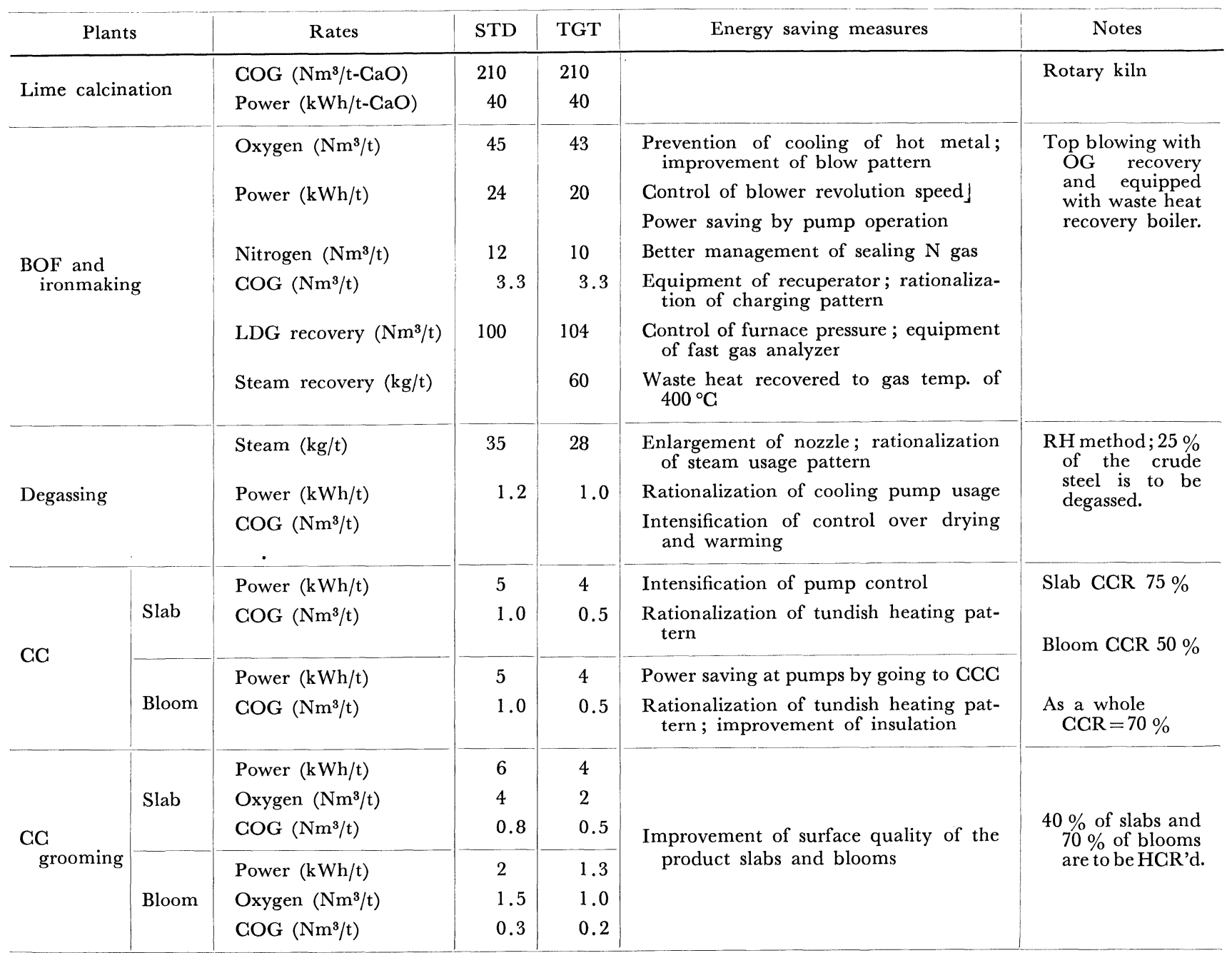


fective CO recovery of $78 \%$ ) at hot metal rate (HMR) of $92 \%$. This should be able to improve to an effective $\mathrm{CO}$ recovery of $83 \%$ or $104 \mathrm{Nm}^{3} / \mathrm{t}$ by improving the precision of the gas analyzer and of furnace pressure control. This gives the TGT, in which the heat of LDG is recovered to a gas temperature of $400{ }^{\circ} \mathrm{C}$ by the OG boiler to generate process steam at $60 \mathrm{~kg} / \mathrm{t}$.

One quarter of the steel is to be treated in the degassing furnace of RH type. The STD steam rate of $35 \mathrm{~kg} / \mathrm{t}$ will be reduced by 7 by shortening the processing time, by selecting the immersion nozzle properly, and by correcting the process pattern.

In the CC (slabs and blooms), intensification of coolant pump control and increased productivity by resorting to CCC (continuous continuous casting) are taken into account.

In the CG Grooming, $40 \%$ of the slabs and $70 \%$ of the blooms are to be hot charged. Because of this, as well as of improved surface quality, the slab cooler, the cold scarfers, and such, those equipment that are crowding the grooming line, are dispensed with.

The STD energy flow is shown in Fig. 10. The temperature drop from tapping to degassing or casting, which runs up to as much as 50 to $60^{\circ} \mathrm{C}$, can be cut down by $15^{\circ} \mathrm{C}$ by providing a cover to the ladle. This means that the end point of blowing may be lowered by that much, the dephosphorization efficiency increased, quantity of lime reduced, quantity of slag decreased, yield improved, quantity of deoxidizer reduced, and, as a consequence, as much as 10 to $12 \times$ $10^{3} \mathrm{kcal} / \mathrm{t}$-crude steel may readily be saved. Besides, pretreatment of molten pig and the combined, or the top-and-bottom, blowing practice for BOF, the two technologies that are spreading rapidly, will result in a decrease of $\mathrm{O}_{2}$ by improving the decarburization efficiency, decrease of $\mathrm{Al}$ due to decreased dissolved $\mathrm{O}$, general improvement of yield, and increase in LDG recovery, all of which will in turn bring about further energy saving of 20 to $30 \times 10^{3} \mathrm{kcal} / \mathrm{t}$.

\section{Variation in the CG Ratio}

A case of CCR (continuous casting ratio) of $80 \%$, an intensification by $10 \%$ over the STD to be directed to slabmaking, is examined to see how much energy can be saved by improving the yield. The result is shown in Table 17, where it will be seen that a $10 \%$ increase in CCR is equivalent to $14.9 \times 10^{3} \mathrm{kcal} / \mathrm{t}$ slab.

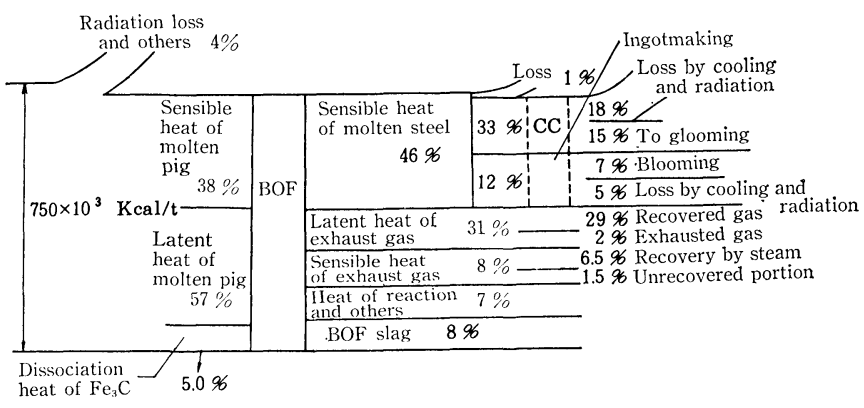

Fig. 10. Energy flow through BOF in STD operation.
Nextly, for a given gross quantity of rolled products, the quantities of necessary molten pig with or without purchased scrap (i.e., the in-house return scrap only) are calculated. Here, the yields across any two processes are assumed to remain unaffected, and the in-house return scrap is computed by (molten steel-products $) \times 0.807$. The materials flow is shown in Table 18. It will be seen that no purchased scrap promises an improved yield and resultant substantial decrease of needed molten pig, and that this decrease in pig is equivalent to energy saving of $c a .10 \times 10^{3}$ $\mathrm{kcal} / \mathrm{t}$-crude steel.

\section{The Ingotmaking Sector}

At the time of data compilation for this study, ${ }^{1)}$ the ingotmaking was undergoing a great change from the old practice under the impacts of rapid increase of GCR, spreading of hot direct rolling (HDR), popularization of CG bloom reheating furnace, improvements in heating pattern of soaking pit, etc. Therefore, the actual achievements of member firms were not on the same level, particularly in the steel mix, production, and track time at the steelmaking sector, so that various rates, especially the FR, differed greatly. Thus, the entire Ingotmaking Sector has been divided into three divisions of the IC (ingot cast) Slab, the IC Billet, and the CG Bloom (bloom to billet), as shown in Fig. 11, and then the steel mix has been determined reasonably though rather arbitrarily.

Table 17. Energy saving due to intensification of GC.

\begin{tabular}{|c|c|c|c|}
\hline & & $\begin{array}{c}(\mathrm{A}) \\
\mathrm{GCR}= \\
70 \%\end{array}$ & $\begin{array}{c}(\mathrm{B}) \\
\mathrm{GCR}= \\
80 \%\end{array}$ \\
\hline \multirow[t]{2}{*}{ Production } & GG (kt-slab/month) & 333.0 & 382.0 \\
\hline & Ingot (kt-slab/month) & 103.0 & 54.0 \\
\hline \multirow[t]{3}{*}{ CG } & Heat $\left(10^{3} \mathrm{kcal} / \mathrm{t}-\mathrm{slab}\right)$ & 8.6 & 8.4 \\
\hline & Power (kWh/t-slab) & 11 & 10 \\
\hline & Total $\left(10^{3} \mathrm{kcal} / \mathrm{t}-\mathrm{slab}\right)$ & 35.6 & 32.9 \\
\hline \multirow[t]{4}{*}{ Bloom } & Heat $\left(10^{3} \mathrm{kcal} / \mathrm{t}\right.$-slab $)$ & 66 & 66 \\
\hline & Power (kWh/t-slab) & 34 & 37 \\
\hline & Steam (kg/t-slab) & 7.0 & 7.7 \\
\hline & Total $\left(10^{3} \mathrm{kcal} / \mathrm{t}-\mathrm{slab}\right)$ & 154.9 & 162.9 \\
\hline \multicolumn{2}{|c|}{ Grand total : $\left(10^{3} \mathrm{kcal} / \mathrm{t}-\mathrm{slab}\right)$} & 63.9 & 49.0 \\
\hline
\end{tabular}

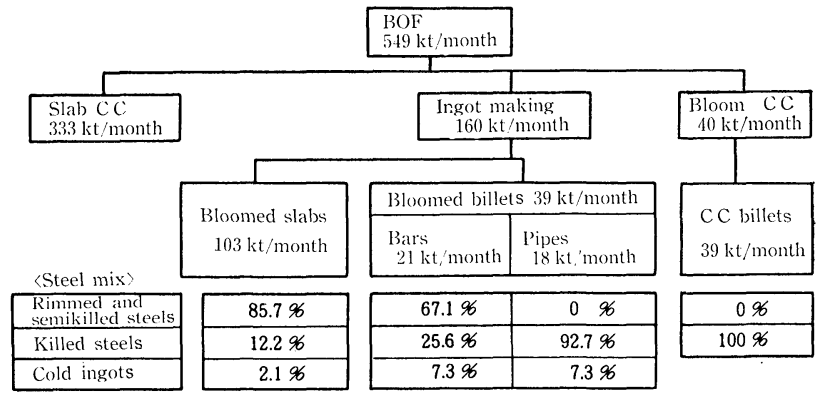

Fig. 11. Production and steel mix of ingotmaking sector. 
Table 18. Changes in the materials flow due to changes in the HMR. (unit $\mathrm{kg} / \mathrm{month}$ )

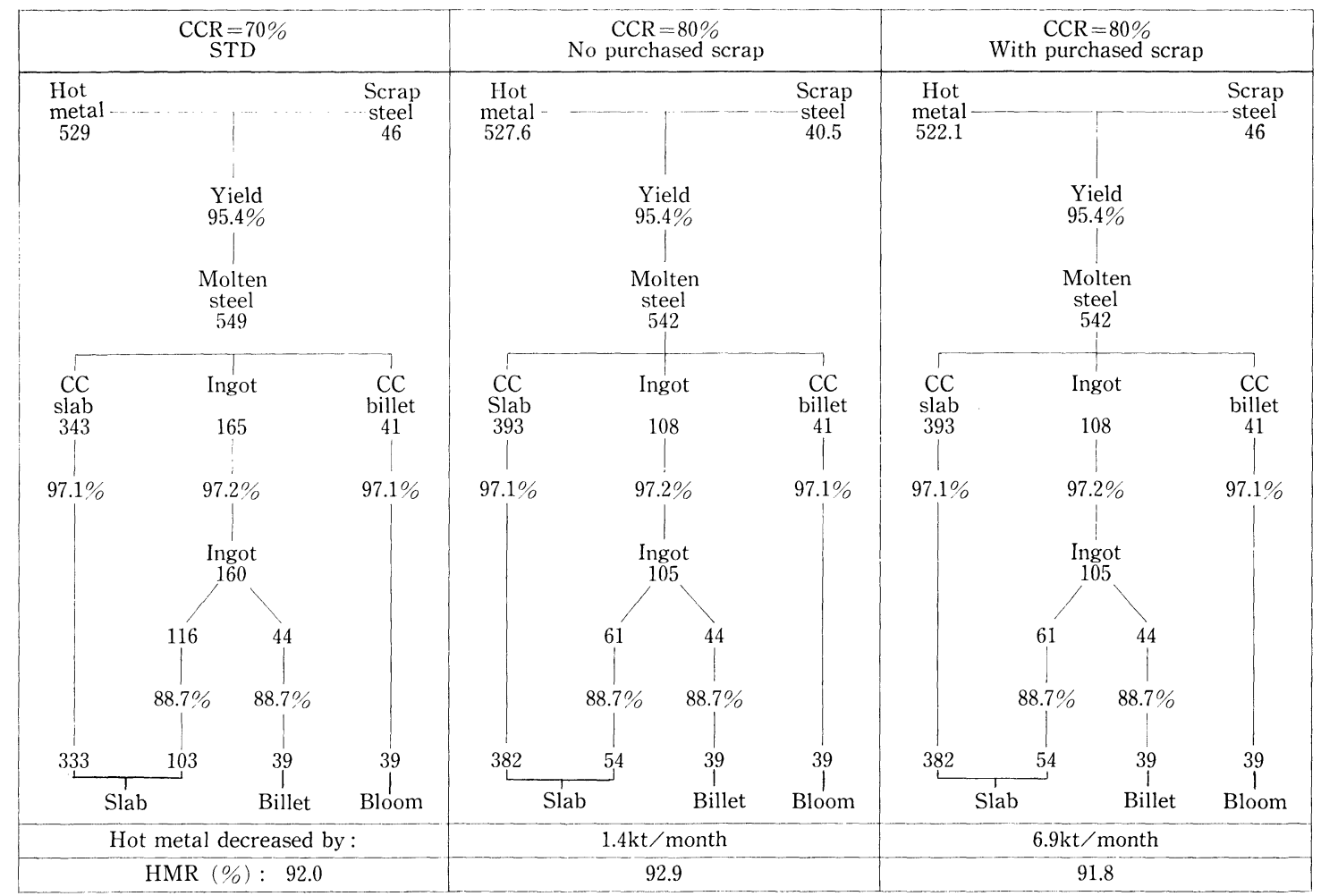

\section{The STD and the TGT Rates for IC Slab and IC Billet} Divisions

The soaking pit is of a capacity of $250 \mathrm{t} / \mathrm{ch}$, of the top firing type, burning a mixed byproduct gas ( $M$ gas) of $2500 \mathrm{kcal} / \mathrm{Nm}^{3}$ with air preheated to $450^{\circ} \mathrm{C}$. The FR was considered individually by hot ingot and cold ingot, both of the rimmed steel or the killed steel. The STD is related to those actual achievements of the category of "very good ", while the TGT is based on the "best achieved" with further energy saving taken into account. Those values for slab soaking pit are shown in Table 19, and the energy flow in Fig. 12. The PRs have been computed by the following formulas from the production rates:

\section{STD TGT}

Slab; $y=-0.084 x+43, \quad y=-0.084 x+35$

Billet; $y=-0.2 x+69.5, \quad y=-0.2 x+60.0$

where, $y$ : the $\mathrm{PR}$ in $\mathrm{kWh} / \mathrm{t}$

$x$ : the production rate in $\mathrm{kt} /$ month.

Those rates are all summarized in Table 20, where various rates other than FR and PR are the average of actual achievements both for STD and for TGT.

\section{The STD and the TGT Rates for GG Bloom Division}

The heating of the CC blooms for reducing to billets is being done either in reheating furnace or in soaking pit, of which the latter is generally thought as more advantageous by its better FR. Nevertheless, the reheating furnace is considered here because of its greater flexibility for adopting energy saving measures and of the large production rate $(\mathrm{kt} /$ month) required. Thus, a continuous reheating furnace of $100 \mathrm{t} / \mathrm{h}$ capacity has been selected. The fuel is an $\mathbf{M}$ gas of 2500
Table 19. Operation parameters, TGT rates, and energy saving measures for slabmaking soaking pit.

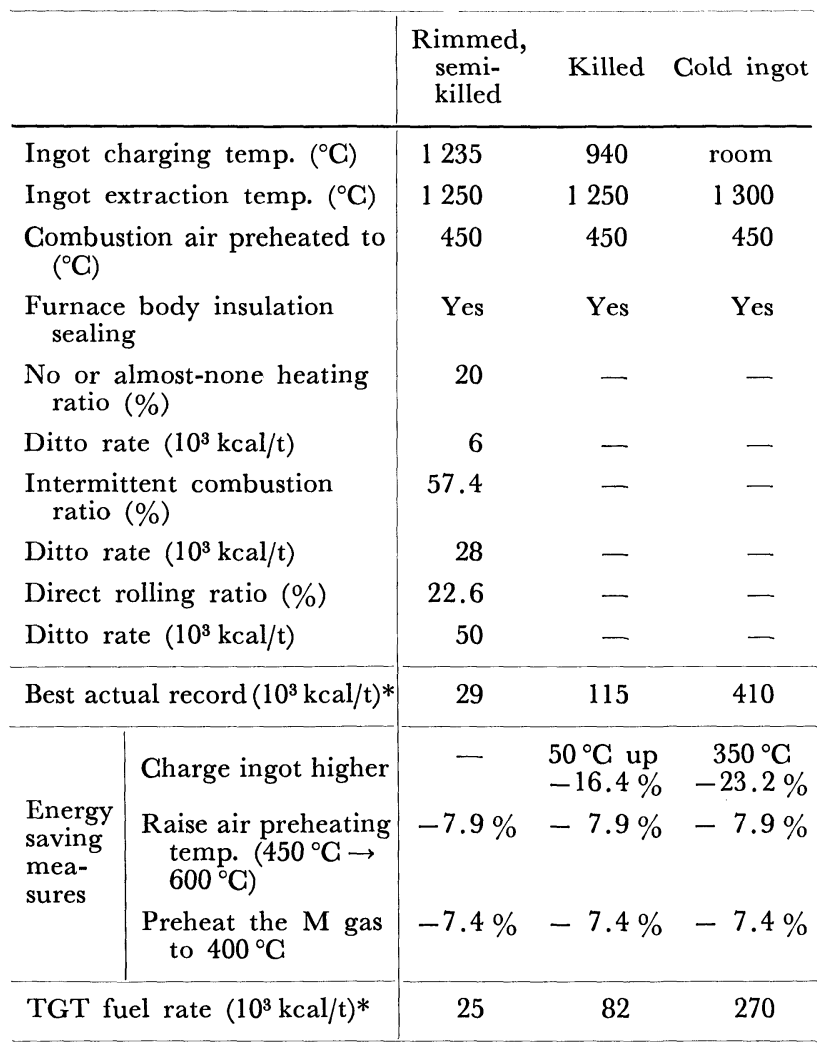

* Ton-heated ingots

$\mathrm{kcal} / \mathrm{Nm}^{3}$, the combustion air is to be preheated to $400{ }^{\circ} \mathrm{C}$, and all the blooms are to be hot charged at $500{ }^{\circ} \mathrm{C}$. 
The STD rate was determined by taking the usual energy saving measures into account over the average actual achievements, from which the TGT rate was derived by assuming practicing of future measures. Those are shown in Table 21. Here, the STD PR,

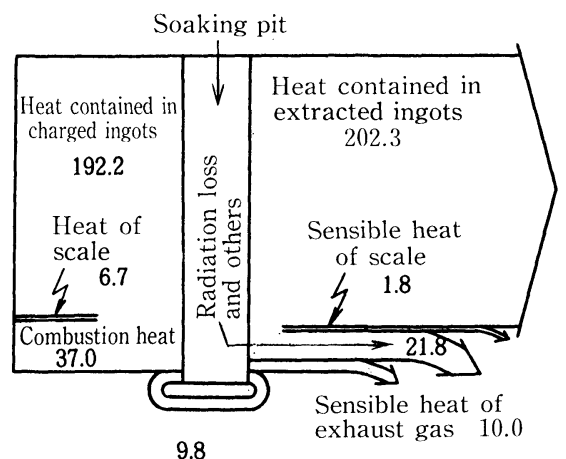

Preheating of

air and $\mathrm{M}$ gas

Unit: $\times 10^{3} \mathrm{kcal} / \mathrm{t}$

Fig. 12. Energy flow through slabmaking reheating furnace in TGT operation.
$34 \mathrm{kWh} / \mathrm{t}$, is the actual results averaged, while the TGT $29 \mathrm{kWh} / \mathrm{t}$, some $16 \%$ less, is when the combustion blower revolution control and power saving at the mill table drive motors are practiced.

The utilities like steam and hot scarfer fuel have been set as shown in Table 20. The energy flow at the bloom heating furnace for TGT operation is shown in Fig. 13.

\section{The Rolling Sector}

The major energies being consumed in the Rolling Sector are the fuels for reheating furnaces, heat treatment furnaces, and annealing furnaces, and the electric power for rolling mills. The FR for the continuous reheating furnace was computed out by taking the heat balance on actual achievements considering the radiation loss from furnace body, loss due to cooling water, and the quantity of scale.

To accomplish better heat economy, the reheating furnace may be either the extended hearth type or the recurrent waste heat recovery type. Of the two the latter was adopted because it is better adaptable to

Table 20. Energy rates for slab and billet plants.

\begin{tabular}{|c|c|c|c|c|c|c|c|}
\hline & & \multicolumn{2}{|c|}{ Slabs } & \multicolumn{4}{|c|}{ Billets } \\
\hline & & \multirow{2}{*}{ STD } & \multirow{2}{*}{ TGT } & \multicolumn{2}{|c|}{ STD } & \multicolumn{2}{|c|}{ TGT } \\
\hline & & & & Bars & Pipes & Bars & Pipes \\
\hline \multirow{4}{*}{ Fuel rates } & Rimmed $\left(10^{3} \mathrm{kcal} / \mathrm{t}\right.$-heated ingot) & $40(84)$ & 25 & $114(119)$ & - & 44 & - \\
\hline & Killed ( $10^{3} \mathrm{kcal} / \mathrm{t}$-heated ingot) & $115(224)$ & 82 & $189(218)$ & 224 & 100 & 155 \\
\hline & Gold ingot $\left(10^{3} \mathrm{kcal} / \mathrm{t}\right.$-heated ingot) & $399(418)$ & 270 & $441(523)$ & 453 & 285 & 340 \\
\hline & Total $\left(10^{3} \mathrm{kcal} / \mathrm{t}\right.$-heated ingot) & 55 & 37 & 157 & 240 & 76 & 168 \\
\hline \multicolumn{2}{|c|}{ Power rate $(\mathrm{kWh} / \mathrm{t}$-slab) } & 34 & 26 & \multicolumn{2}{|c|}{62} & \multicolumn{2}{|c|}{52} \\
\hline \multirow{4}{*}{ Other rates } & Hot scarfer fuel $\left(10^{3} \mathrm{kcal} / \mathrm{t}\right.$-slab) & 4 & 4 & \multicolumn{2}{|c|}{1} & \multicolumn{2}{|c|}{1} \\
\hline & Steam (kg/t-slab) & 7 & 7 & \multicolumn{2}{|c|}{12} & \multicolumn{2}{|c|}{12} \\
\hline & Compressed air $\left(\mathrm{Nm}^{3} / \mathrm{t}\right.$-slab) & 13 & 13 & \multicolumn{2}{|c|}{25} & \multicolumn{2}{|c|}{25} \\
\hline & Water $\left(\mathrm{m}^{3} / \mathrm{t}-\mathrm{slab}\right)$ & 12 & 12 & \multicolumn{2}{|c|}{9} & \multicolumn{2}{|c|}{9} \\
\hline
\end{tabular}

Note: Parenthesized figures are averages of $\mathrm{N}=8$ for slabs and $\mathrm{N}=4$ for billets.

Table 21. Energy saving measures and TGT rates for bloom-making reheating furnace.

\begin{tabular}{|c|c|c|c|c|}
\hline & Energy saving measures & $\begin{array}{l}\text { Reduction } \\
(\%)\end{array}$ & $\left|\begin{array}{c}\text { Fuel rate } \\
\left(10^{3} \mathrm{kcal} / \mathrm{t}-\right. \\
\text { heated ingot })\end{array}\right|$ & Notes \\
\hline \multirow[t]{2}{*}{ Present } & & & 300 & All the ingots to be $\mathrm{HC}^{\prime}$ ed at $500^{\circ} \mathrm{C}$ \\
\hline & $\begin{array}{l}\text { Charging temp. raised by } 200^{\circ} \mathrm{C} \\
\text { Improved combustion and } \\
\text { strengthened insulation } \\
\text { Light load operation } \\
\text { Better use of recuperator } \\
\text { Improved heat pattern on DDG }\end{array}$ & $\begin{array}{r}20 \\
3.4 \\
8.0 \\
9.0 \\
10.0\end{array}$ & & $\begin{array}{l}\text { Improved burner, more stringent use of } \\
\mathrm{O}_{2} \text {, and others } \\
\text { Raise the air preheating temp. from } \\
400 \text { to } 600^{\circ} \mathrm{C}\end{array}$ \\
\hline \multirow[t]{2}{*}{ STD } & Sum total of above measures & 41.7 & 175 & \\
\hline & $\begin{array}{l}\text { Improved furnace profile } \\
\text { Preheating of } \mathbf{M} \text { gas }\end{array}$ & $\begin{array}{l}1.7 \\
5.9\end{array}$ & & To a gas temp. of $350^{\circ} \mathrm{C}$ \\
\hline TGT & Sum total of above measures & 7.5 & 162 & \\
\hline
\end{tabular}




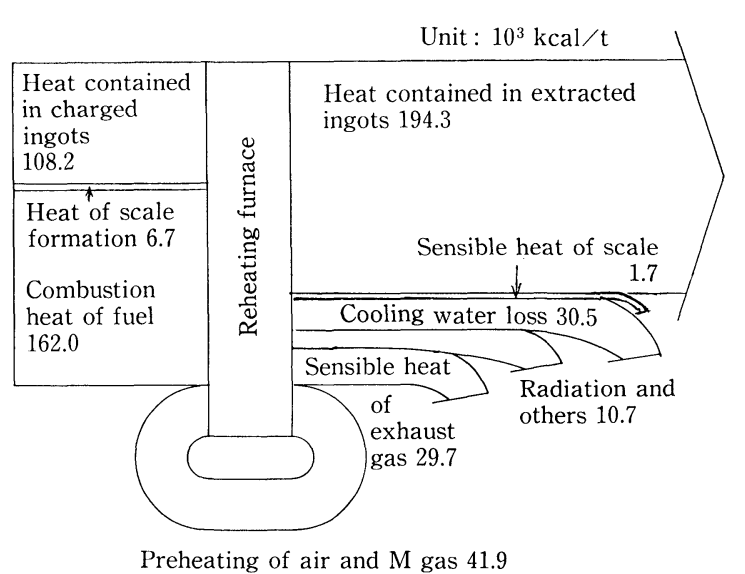

Fig. 13. Energy flow through bloomer reheating furnace in TGT operation.

the hot charge rolling (HCR), whereas the furnace efficiency and the heat recovery rate are the same for both at $c a .70 \%$ and $c a .62 \%$, respectively, when examined on the basis of charging cold, extracting at $1250{ }^{\circ} \mathrm{C}$, a stack of $150 \mathrm{~m}$ high, and a draft of $50 \mathrm{mmAq}$. The STDs were determined on the basis of actual achievements, while the TGTs are for low temperature extraction practice that necessitates an increase in the PR with other utilities held unchanged. 1. The STD and the TGT Rates for the Rolling Sector (1) The Hot Strip Mill Plant

The reheating furnace for the hot rolling line is of the walking beam type continuous furnace with a length of $45 \mathrm{~m}$, width $10.5 \mathrm{~m}$, capacity $300 \mathrm{t} / \mathrm{h}$, and handling slabs of an average thickness $230 \mathrm{~mm}$ and average weight $17.2 \mathrm{t}$. The STD is set, as seen in Table 2, for a charging temperature of $450{ }^{\circ} \mathrm{C}$, an HCR ratio of $19 \%$, an $\mathrm{HDR}$ rate of $20 \mathrm{kt} / \mathrm{month}$, or $6 \%$, and a waste heat recovery of $65 \%$, whereas the TGT is for a higher charging temperature of $550{ }^{\circ} \mathrm{C}$, a higher $\mathrm{HCR}$ ratio of $40 \%$, though no HDR, where $89 \times 10^{3} \mathrm{kcal} / \mathrm{t}$ is assumed for HDR as the holding FR*, and $10 \times 10^{3} \mathrm{kcal} / \mathrm{t}$ for $\mathrm{HCR}$ as the warming $\mathrm{FR}^{+4}$. Those rates and the heat balance are given in Tables 22 and 23 for cold charging and hot charging. It will be noted that the PR for TGT is up $2 \mathrm{kWh} / \mathrm{t}$ because the extraction temperature is lowered from $1200{ }^{\circ} \mathrm{C}$ by $30^{\circ} \mathrm{C}$.

(2) The Plate Mill Plant

The continuous reheating furnace is of the walking beam type, $35 \mathrm{~m}$ long, $8 \mathrm{~m}$ wide, handling slabs of a mean thickness $230 \mathrm{~mm}$ and a mean weight $9 \mathrm{t}$ at a rate of $150 \mathrm{t} / \mathrm{h}$. The STD operation is a charging at $450{ }^{\circ} \mathrm{C}$, an $\mathrm{HCR}$ ratio of $30 \%$, extraction at $1200^{\circ} \mathrm{C}$, waste heat recovery of $65 \%$ (preheating the combustion air to $600{ }^{\circ} \mathrm{C}$ and the fuel gas to $230{ }^{\circ} \mathrm{C}$ ), while that for $\mathrm{TGT}$ is for charging at $550{ }^{\circ} \mathrm{C}, \mathrm{HCR}$ ratio
Table 22. Heat balance at the hot rolling reheating furnace.

\begin{tabular}{|c|c|c|c|c|c|}
\hline & \multicolumn{2}{|c|}{ Cold slab } & \multicolumn{2}{|c|}{ Hot charging } \\
\hline & & $\begin{array}{l}\text { STD } \\
\text { im- } \\
\text { proved } \\
\text { heat } \\
\text { recovery }\end{array}$ & $\begin{array}{c}\text { TGT } \\
\text { low } \\
\text { temp. } \\
\text { extrac- } \\
\text { tion }\end{array}$ & STD & $\begin{array}{l}\text { TGT } \\
\text { low } \\
\text { temp. } \\
\text { extrac- } \\
\text { tion }\end{array}$ \\
\hline \multicolumn{2}{|c|}{ Waste heat recovery $(\%)$} & 65 & 65 & 65 & 65 \\
\hline \multicolumn{2}{|c|}{$\begin{array}{l}\text { Exhaust gas temp. } \\
\text { perator inlet }\left({ }^{\circ} \mathbf{C}\right)\end{array}$} & 671 & 652 & 616 & 607 \\
\hline \multicolumn{2}{|c|}{$\begin{array}{l}\text { Combustion air preheated to } \\
\left({ }^{\circ} \mathbf{C}\right)\end{array}$} & 610 & 592 & 557 & 548 \\
\hline \multicolumn{2}{|c|}{ Fuel gas preheated to $\left({ }^{\circ} \mathrm{C}\right)$} & 257 & 251 & 235 & 231 \\
\hline \multicolumn{2}{|c|}{$\begin{array}{l}\text { Exhaust gas temp. at recu- } \\
\text { perator outlet }\left({ }^{\circ} \mathrm{C}\right)\end{array}$} & 237 & 231 & 218 & 215 \\
\hline \multicolumn{2}{|c|}{ Slab charging temp. $\left({ }^{\circ} \mathrm{C}\right)$} & 30 & 30 & 450 & 550 \\
\hline \multicolumn{2}{|c|}{ Slab extraction temp. $\left({ }^{\circ} \mathrm{C}\right)$} & 1200 & 1170 & 1200 & 1170 \\
\hline \multicolumn{6}{|c|}{ Heat balance table $\left(10^{3} \mathrm{kcal} / \mathrm{t}\right)$} \\
\hline \multirow{4}{*}{$\begin{array}{l}\text { 芯 } \\
\text { 品 }\end{array}$} & Fuel combustion heat & 261 & 253 & 195 & 169 \\
\hline & Recovered heat & 65 & 61 & 44 & 38 \\
\hline & Charged slab sensible heat & 3 & 3 & 57 & 73 \\
\hline & Total & 321 & 317 & 296 & 280 \\
\hline \multirow{5}{*}{ 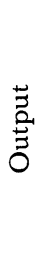 } & $\begin{array}{l}\text { Extracted slab sensible } \\
\text { heat }\end{array}$ & 196 & 190 & 196 & 191 \\
\hline & Exhaust gas sensible heat & 100 & 94 & 68 & 58 \\
\hline & $\begin{array}{l}\text { Radiation from furnace } \\
\text { body }\end{array}$ & 10 & 9 & 9 & 9 \\
\hline & Cooling water loss & 23 & 24 & 23 & 22 \\
\hline & Total & 321 & 317 & 296 & 280 \\
\hline
\end{tabular}

$40 \%$, extraction lowered by $30^{\circ} \mathrm{C}$ (necessarily raising the $\mathrm{PR}$ by $2 \mathrm{kWh} / \mathrm{t}$ ), and the same recovery rate, where the FRs are those that were computed out on the heat balance. Those are shown in Table 23.

As for the batch furnace, on the other hand, both the STD and the TGT rates are those that are estimated from representative values by taking such measures as lowering of the air-to-fuel ratio, intensification of waste heat recovery from 30 to $50 \%$, reduction of the furnace body radiation loss by $60 \%$ with improved insulation. Those are presented in Tables 23 and 24.

The heat treating furnace is a $90 \mathrm{~m}$ long non-oxidizing type that handles plates of $18 \mathrm{~mm}$ mean thickness. Figure 14 shows the relationship between heat treating time and plate thickness as a side information. The rates are the same for STD and for TGT on the basis of popular energy saving measures of low air-tofuel ratio, improved furnace body insulation, improved heat recovery (e.g., the preheating temperature of combustion air is raised up by 150 to $400{ }^{\circ} \mathrm{C}$ for quenching and normalization, and up 100 to $280^{\circ} \mathrm{C}$

* In the modern hot rolling plants, three different methods of HCC (Hot Strip Mill Cold Charging), HCR (Hot Charge Rolling) and HDR (Hot Direct Rolling), each comprising a convenient batch, are practiced. For HCG and HCR, the reheating furnace is kept at a standard operation temperature of, say, $1300^{\circ} \mathrm{C}$. During practicing HDR, when the reheating furnace line is entirely skipped, however, the furnace is held at a lower temperature of, say, $900^{\circ} \mathrm{C}$, which is determined in consideration of fuel economy, the speed of warming up to receive the next HCG and HCR batches, thermal fatigue of refractories, etc.. The fuel rate to keep the furnace in readiness at the low temperature is here termed the " holding FR", while that for warming the furnace again to the operation temperature is here called the "warming FR". 
Table 23. STD and TGT rates for rolling sector.

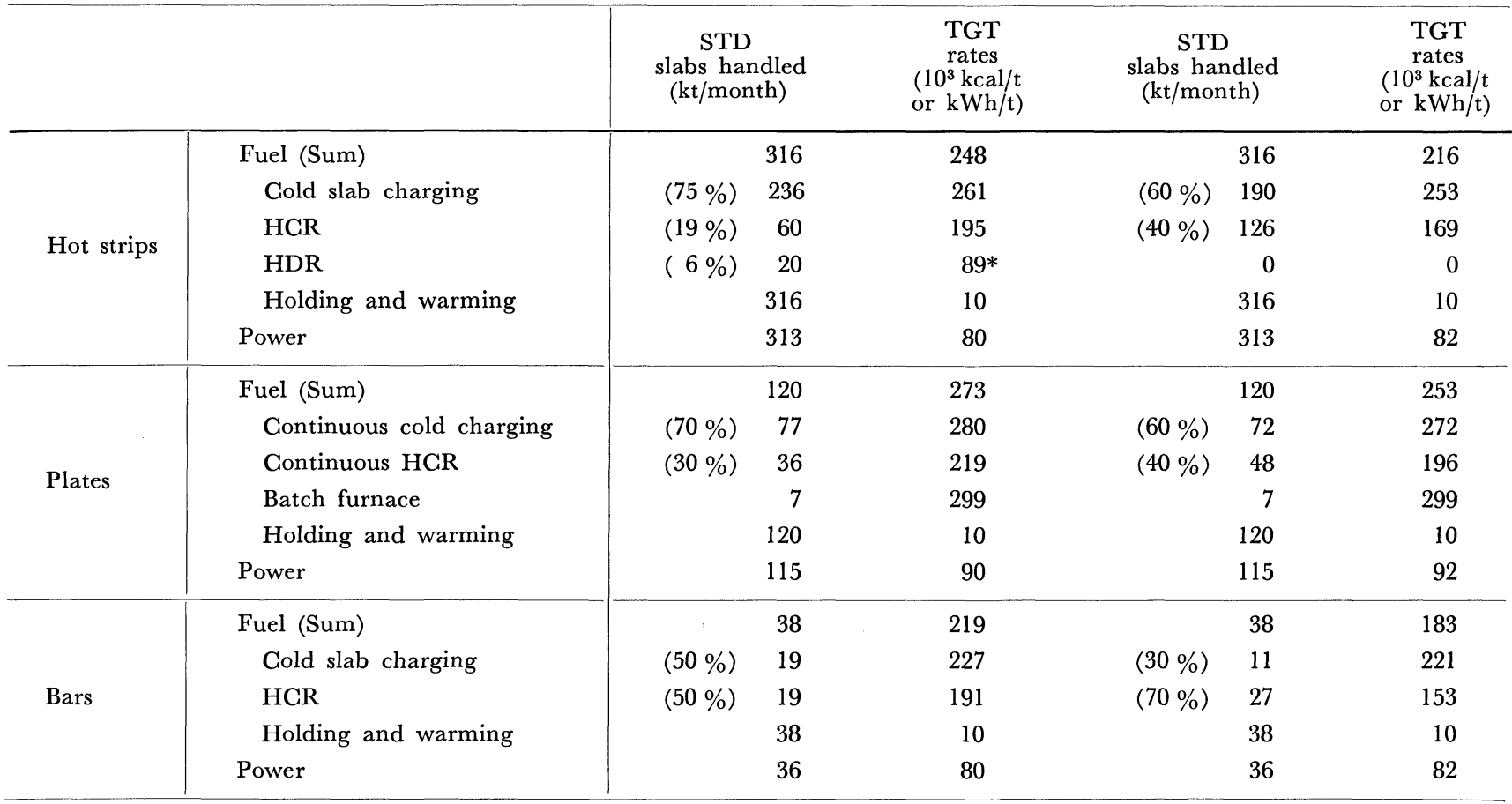

* Holding only

Table 24. Heat balance at the batch furnace.

\begin{tabular}{|c|c|c|c|}
\hline & \multicolumn{2}{|c|}{$\operatorname{Present}^{*} \underset{(=\mathrm{TGT})^{* *}}{\text { STD }}$} \\
\hline \multicolumn{2}{|c|}{ Air-to-fuel ratio } & 1.2 & 1.1 \\
\hline \multicolumn{2}{|c|}{ Waste heat recovery (\%) } & 30 & 50 \\
\hline \multicolumn{2}{|c|}{ Effect of improved insulation (\%) } & 0 & 60 \\
\hline \multicolumn{2}{|c|}{ Furnace body radiation loss $\left(10^{3} \mathrm{kcal} / \mathrm{t}\right)$} & 1010 & 404 \\
\hline \multicolumn{2}{|c|}{$\begin{array}{l}\text { Heat contained in furnace body } \\
\left(10^{3} \mathrm{kcal} / \mathrm{t}\right)\end{array}$} & 3212 & 1285 \\
\hline \multicolumn{2}{|c|}{ Heat balance table $\left(10^{3} \mathrm{kcal} / \mathrm{t}\right)$} & & \\
\hline Input & $\begin{array}{l}\text { Fuel combustion heat } \\
\text { Recovered heat } \\
\text { Charged slab sensible heat } \\
\text { Total }\end{array}$ & $\begin{array}{r}433 \\
62 \\
3 \\
498\end{array}$ & $\begin{array}{r}299 \\
67 \\
3 \\
369\end{array}$ \\
\hline Output & $\begin{array}{l}\text { Extracted slab sensible heat } \\
\text { Exhaust gas sensible heat } \\
\text { Radiation from furnace body } \\
\text { Heat contained in furnace body } \\
\text { Total }\end{array}$ & $\begin{array}{r}195 \\
209 \\
22 \\
72 \\
498\end{array}$ & $\begin{array}{r}195 \\
136 \\
9 \\
29 \\
366\end{array}$ \\
\hline
\end{tabular}

* Average of several representative furnaces.

** Energy saving measures of lowered air-to-fuel ratio, intensified waste heat recovery, and improved furnace insulation have been presumed.

for tempering), and improved seal for preventing the escape of $\mathrm{N}_{2}$. Those are summarized in Table 25. The PR is set at $155 \mathrm{kWh} / \mathrm{t}$ for quench-and-tempering, and $27.5 \mathrm{kWh} / \mathrm{t}$ for normalization.

(3) The Bar Mill Plant

The reheating furnace is of the walking hearth type, $35 \mathrm{~m}$ long, $10 \mathrm{~m}$ wide, and a capacity of $120 \mathrm{t} / \mathrm{h}$. The billets are $140 \mathrm{~mm}$ square and $1.3 \mathrm{t}$. The STD operation is hot charging at $300{ }^{\circ} \mathrm{C}, \mathrm{HCR}$ ratio $50 \%$,

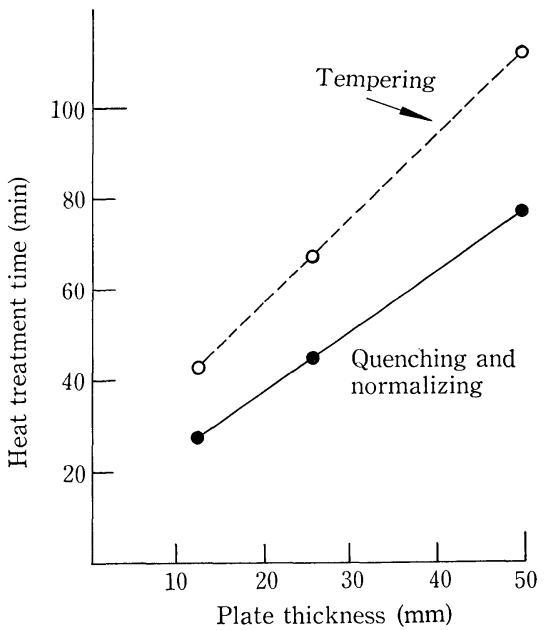

Fig. 14. Relation between plate thickness and heat treatment time.

extraction at $1170{ }^{\circ} \mathrm{C}$, and heat recovery $65 \%$, whereas the TGT is hot charging high at $500^{\circ} \mathrm{C}$, greater HCR ratio of $70 \%$, and extracting low at $1140{ }^{\circ} \mathrm{C}$.

The FR was computed out from the heat balance, and, as may be seen in Table 23, it is even lower than the cases of hot rolling and plate rolling because of the low extraction temperature and thanks to the walking hearth which suffers no cooling water loss. The notion for holding and warming heats and the increased PR on lowered extraction temperature is the same as for the previous two cases.

(4) The Seamless Pipe Mill Plant

The rates, both STD and TGT, are the representative actual results for medium diameter pipes. The continuous reheating furnace for seamless pipe billets is of an FR of $275 \times 10^{3} \mathrm{kcal} / \mathrm{t}$, the rolling $\mathrm{PR}$ is $120 \mathrm{kWh} / \mathrm{t}$, the FR for heat treatment is $350 \times 10^{3}$ 
Table 25. Heat balance at the plate heat treating furnace.

\begin{tabular}{|c|c|c|c|c|c|}
\hline & \multicolumn{2}{|c|}{$\begin{array}{l}\text { Quenching or } \\
\text { normalization }\end{array}$} & \multicolumn{2}{|c|}{ Tempering } \\
\hline & & Present & $\underset{(=\mathrm{TGT})}{\mathrm{STD}}$ & Present & $\begin{array}{c}\text { STD } \\
(=\text { TGT })\end{array}$ \\
\hline \multicolumn{2}{|c|}{ Air-to-fuel ratio } & 1.25 & 1.15 & 1.25 & 1.15 \\
\hline \multicolumn{2}{|c|}{$\begin{array}{l}\text { Combustion air heated } \\
\text { to }\left({ }^{\circ} \mathrm{C}\right)\end{array}$} & 250 & 400 & 180 & 280 \\
\hline \multicolumn{2}{|c|}{$\begin{array}{l}\text { Radiation from furnace } \\
\text { body }\left(10^{3} \mathrm{kcal} / \mathrm{h}\right)\end{array}$} & 1275 & 953 & 654 & 491 \\
\hline \multicolumn{2}{|c|}{ Nitrogen rate $\left(\mathrm{Nm}^{3} / \mathrm{t}\right)$} & 110 & 60 & 110 & 60 \\
\hline \multicolumn{6}{|c|}{$\begin{array}{l}\text { Heat balance table } \\
\quad\left(10^{3} \mathrm{kcal} / \mathrm{t}\right)\end{array}$} \\
\hline \multirow{4}{*}{ 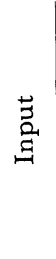 } & $\begin{array}{l}\text { Fuel combustion } \\
\text { heat }\end{array}$ & 400 & 312 & 216 & 176 \\
\hline & $\begin{array}{l}\text { Preheated air sensi- } \\
\text { ble heat }\end{array}$ & 30 & 37 & 11 & 14 \\
\hline & $\begin{array}{l}\text { Charged slab sensi- } \\
\text { ble heat }\end{array}$ & 3 & 3 & 3 & 3 \\
\hline & Total & 433 & 352 & 230 & 193 \\
\hline \multirow{5}{*}{ 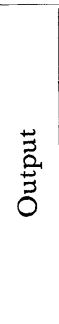 } & $\begin{array}{l}\text { Extracted slab sen- } \\
\text { sible heat }\end{array}$ & 145 & 145 & 92 & 92 \\
\hline & $\begin{array}{l}\text { Exhaust gas sensi- } \\
\text { ble heat }\end{array}$ & 212 & 153 & 78 & 59 \\
\hline & $\begin{array}{c}\text { Nitrogen sensible } \\
\text { heat }\end{array}$ & 32 & 17 & 23 & 12 \\
\hline & $\begin{array}{l}\text { Radiation from } \\
\text { furnace body }\end{array}$ & 44 & 34 & 34 & 27 \\
\hline & Total & 433 & 352 & 230 & 193 \\
\hline
\end{tabular}

$\mathrm{kcal} / \mathrm{t}$, and the $\mathrm{PR}$ is $27.5 \mathrm{kWh} / \mathrm{t}$.

(5) The Cold Rolling Plant

The practical results achieved by the individual lines of the member firms have been adopted both for the STD and for the TGT. Those are shown in Table 26.

(6) Summary

The Table 27 gives an overall summation of STD and TGT rates by individual production lines through those five plants. It will be seen that the per product tonnage overall energy rate is $775.9 \times 10^{3} \mathrm{kcal} / \mathrm{t}$ for STD, which can be improved further by $23.1 \times 10^{3}$ $\mathrm{kcal} / \mathrm{t}$ to $752.8 \times 10^{3} \mathrm{kcal} / \mathrm{t}$, which is the TGT.

In this table, some numerical discrepancies may be noted against Tables 22 to 26 . Those are due to the adoption of different denominators for the same numerator; for example, for the pickling line, the denominator is the tonnage of coils with scale still adhered onto in Table 26 (a PR of $6.5 \mathrm{kWh} / \mathrm{t}$ ), whereas in Table 27 it is that of descaled coils $(6.7 \mathrm{kWh} / \mathrm{t})$. Those two are equated by the pickling yield of $97 \%$ in such a way as $6.5 / 0.97=6.7$.

\section{Operational Variations for Rolling Sector}

Effects of practicing (a) lowering of extraction temperature, (b) raising of the hot charging temperature, and (c) increasing of the HCR ratio on the total energy are examined for the hot rolling, the plate rolling, and the bar rolling plants. The results are summarized in Fig. 15, where it will be noticed that the effect of those three measures taken integrally is great-

Table 26. STD (=TGT) rates for cold rolling plants.

\begin{tabular}{l|cccccccc} 
& Pickling & $\begin{array}{c}\text { Cold } \\
\text { rolling }\end{array}$ & G.A.L. & E.C.L. & $\begin{array}{c}\text { Batch } \\
\text { annealing }\end{array}$ & C.G.L. & $\begin{array}{c}\text { Temper } \\
\text { rolling }\end{array}$ & E.T.L. \\
\hline Fuel $\left(10^{3} \mathrm{kcal} / \mathrm{t}\right)$ & - & - & 169 & - & 175 & 230 & - & - \\
Power $(\mathrm{kWh} / \mathrm{t})$ & 6.5 & 63 & 45 & 10 & 20 & 69 & 10 & 140 \\
Steam $(\mathrm{kg} / \mathrm{t})$ & 30 & - & 90 & 30 & - & 70 & - & 120 \\
\hline
\end{tabular}

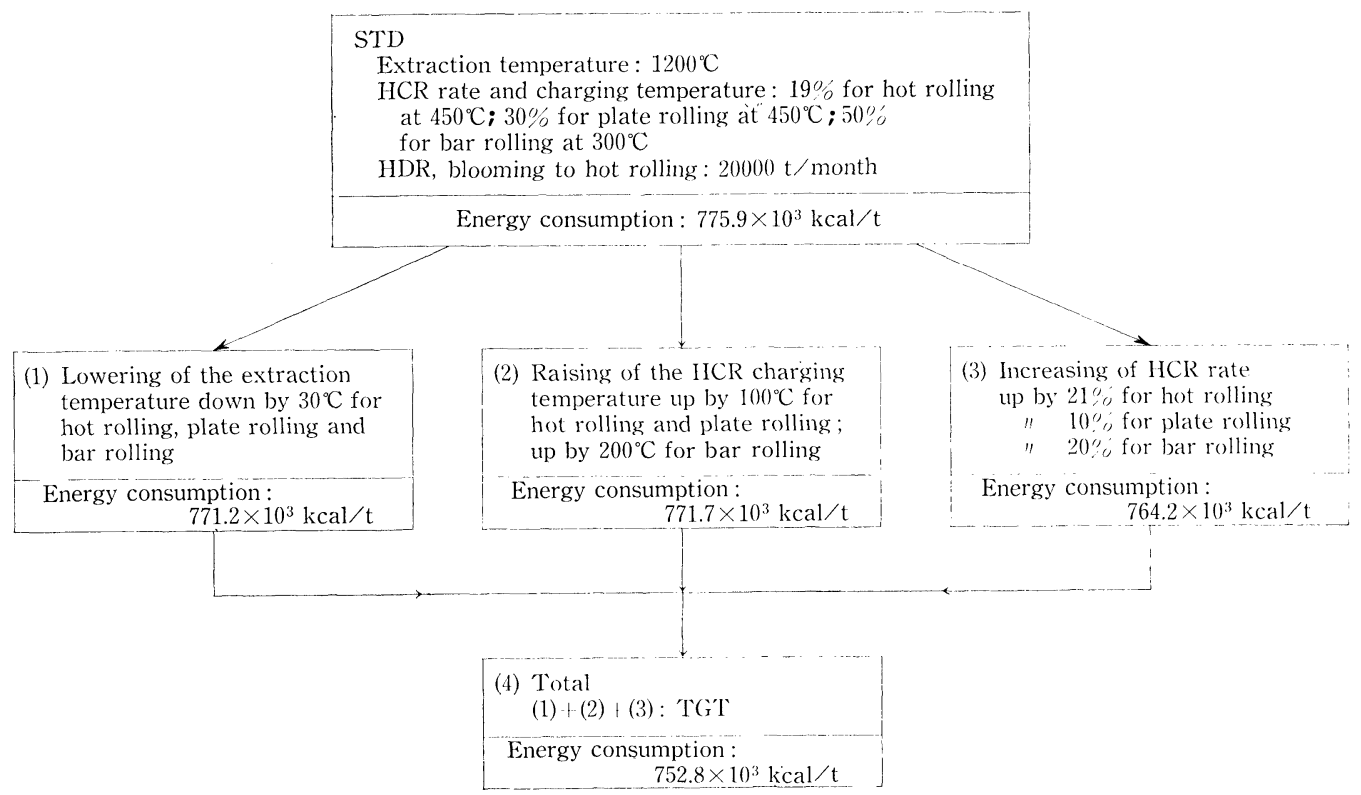

Fig. 15. Effects of operation variations of rolling sector. 
Table 27. The STD and the TGT rates for the rolling sector.

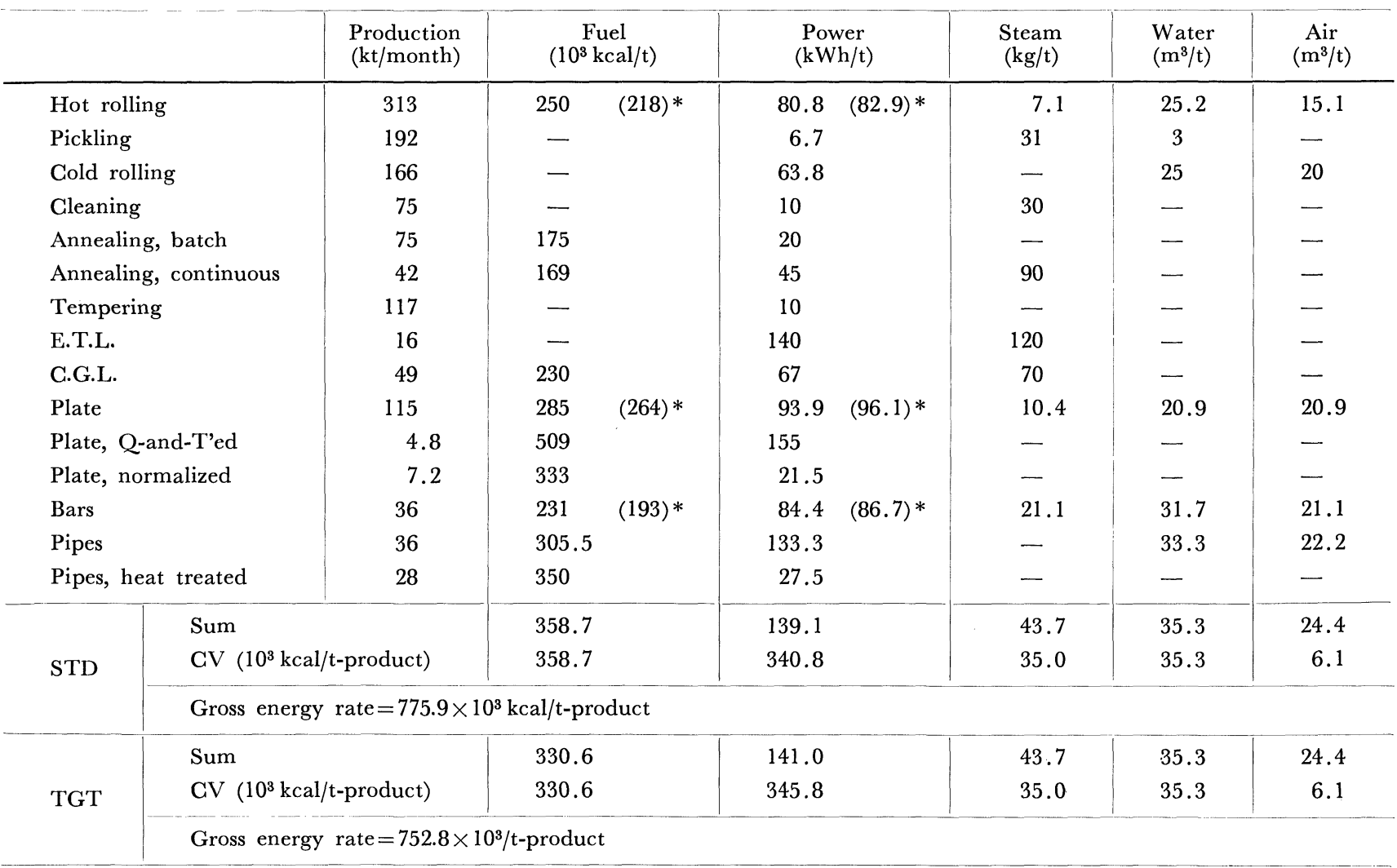

* Parenthesized figures are TGT values.

Table 28. Yields and energy rates through steelmaking and rolling processes.

\begin{tabular}{|c|c|c|c|c|c|c|}
\hline & & \multicolumn{2}{|c|}{ Continuous casting } & \multicolumn{3}{|c|}{ Ingotmaking } \\
\hline & & Cold charging & HaR & Cold charging & HDR & HGR \\
\hline \multicolumn{2}{|c|}{ Charging temp. $\left({ }^{\circ} \mathrm{C}\right)$} & Room temp. & 550 & Room temp. & - & 850 \\
\hline \multirow{4}{*}{ Yield (\%) } & Continuous casting & 98.00 & 98.00 & - & - & - \\
\hline & Ingotmaking & - & - & 92.00 & 91.00 & 92.00 \\
\hline & Hot rolling & 97.15 & 97.25 & 97.15 & 97.75 & 97.25 \\
\hline & Overall & 95.21 & 95.31 & 89.38 & 88.98 & 89.47 \\
\hline \multirow{4}{*}{$\begin{array}{l}\text { Energy rate } \\
\quad\left(10^{3} \mathrm{kcal} / \mathrm{t}\right)\end{array}$} & Continuous casting & 37.0 & 37.0 & - & - & - \\
\hline & Ingotmaking & - & - & 159.6 & 182.7 & 159.6 \\
\hline & Hot rolling & 502.8 & 416.4 & 502.8 & 331.9 & 386.1 \\
\hline & Total & 539.8 & 453.4 & 662.4 & 514.6 & 545.7 \\
\hline
\end{tabular}

er than the simple summation of the three. In the calculation, the rates for steam, water and compressed air were always the STD values.

\section{Operation Variations Bridging Steelmaking and Roll-} ing Sectors

The operation bridging the Steelmaking and the Rolling Sectors is diversifying because of increasing CGR and enlargement of HCR and HDR portions. For this, five variations were considered in order to compare the resultant rates and gross yield under the following presumptions.

(1) The steel is rimmed, whose ingot yield is as given by the report of the Ingotmaking Research Group, the Joint Research Society. ${ }^{6}$
(2) The decrease of ingot yield when HDR'ed, increase of hot rolling yield, and increase of hot rolling yield when HCR'ed are all as given by the report of the Hot Strip Research Group, the Joint Research Society. ${ }^{\text {) }}$

(3) The ingotmaking FR is $32 \times 10^{3} \mathrm{kcal} / \mathrm{t}$ for ordinary rimmed steels and $50 \times 10^{3} \mathrm{kcal} / \mathrm{t}$ for the HDR stocks.

(4) The CG grooming is excluded from the discussion.

(5) The reheating furnace FR when hot charging at $850{ }^{\circ} \mathrm{C}$ for $\mathrm{HCR}$ is $140 \times 10^{3} \mathrm{kcal} / \mathrm{t}$.

The result is as shown in Table 28. It will be seen that the difference in the yield between the best, the 
case of CC stock HCR'ed, and the worst, that of cold ingot, is $5.93 \%$, where the energy rate difference is as much as $209 \times 10^{3} \mathrm{kcal} / \mathrm{t}$. Between the two practices in the $\mathrm{CG}$ to hot rolling, the $550^{\circ} \mathrm{C}$ hot charging marks $86.4 \times 10^{3} \mathrm{kcal} / \mathrm{t}$ less than the cold charging. These observations show how great the effects of CG, HCR, and HDR are for yield and energy saving.

\section{Energy Balance of the Model Steel Works}

The total energy balance through the entire Model Steel Works is calculated on the basis of the operating conditions of Chapter II and the energy saving measures and the variations discussed in Chapter III for both the STD and the TGT as shown in Table 29. The presumptions involved are:

(1) The CVs of various fuels and utilities are as given by Table 30 .
(2) Distribution of fuel gases, though should be done by considering furnace efficiencies, gas balance, layout of the consuming apparatuses, etc. as a grand system, are unequivocally set as follows: $\mathbf{M}$ gases, each of an appropriate $\mathrm{CV}$, for the coke oven and the hot stove; an M gas of $2500 \mathrm{kcal} / \mathrm{Nm}^{3}$ for the soaking pit, reheating furnace and lime calcinator kiln; and COG for furnaces other than those and including the heat treating furnaces (Table 31).

(3) As the demand on the power and utility is so much dependent on the local circumstances that surround the steel works, no detailed restrictions were imposed on the equipment, but only the following specifications are set for calculations:

(i) Power Generation

The power boilers are all to burn the byproduct gas that is left after distributed to other equipment,

Table 29. Summary of major STD and TGT rates.

\begin{tabular}{|c|c|c|}
\hline & STD & TGT \\
\hline Coke oven & Coking $\mathrm{FR}=576 \times 10^{3} \mathrm{kcal} / \mathrm{t}$-coal & $\begin{array}{l}\text { Provision of CDQ for power and/or steam gen- } \\
\text { eration }\end{array}$ \\
\hline Sintering & $\begin{array}{l}\text { Breeze rate }=45 \mathrm{~kg} / \mathrm{t} \\
\text { Power rate }=44 \mathrm{kWh} / \mathrm{t} \\
\quad \text { (including power for desulfurization plant) }\end{array}$ & $\begin{array}{l}\text { Practice of combustion air preheating, preheated } \\
\text { sintering, and steam generation by utilizing } \\
\text { the cooler exhaust gas }\end{array}$ \\
\hline $\mathrm{BF}$ & $\begin{array}{l}\mathrm{FR}=450 \mathrm{~kg} / \mathrm{t}(\mathrm{CR}=415, \mathrm{OR}=35) \\
\text { Hot stove } \mathrm{FR}=490 \times 10^{3} \mathrm{kcal} / \mathrm{t} \text { with combus- } \\
\text { tion air preheated by waste gas } \\
\text { TRT } \\
\text { Dehumitizer }\end{array}$ & $\begin{array}{l}\mathrm{FR}=446 \mathrm{~kg} / \mathrm{t}(\mathrm{CR}=411, \mathrm{OR}=35) \\
\text { Hot stove } \mathrm{FR}=476 \times 10^{3} \mathrm{kcal} / \mathrm{t} \text { with combustion } \\
\text { air preheated by waste gas } \\
\text { TRT } \\
\text { Dehumitizer } \\
\text { Top pressure equalizing } / \text { relieving recovery } \\
\text { Top gas dry dust collector } \\
\text { Recovery of slag sensible heat }\end{array}$ \\
\hline BOF \& CC & $\begin{array}{l}\text { LDG recovery rate }=100 \mathrm{Nm}^{3} / \mathrm{t}(\mathrm{HMR}=92 \%) \\
\mathrm{CCR}=70 \%\end{array}$ & $\begin{array}{l}\text { LDG recovery rate }=104 \mathrm{Nm}^{3} / \mathrm{t} \\
\text { OG heat recovery by steam generation }\end{array}$ \\
\hline Ingotmaking & \begin{tabular}{llc} 
Slab, rimmed & \multicolumn{2}{c}{$40 \times 10^{3} \mathrm{kcal} / \mathrm{t}$-ingot } \\
Slab, killed & 115 &, \\
Billet, rimmed & 114 &, \\
Billet, killed & 215 &, \\
(for bars and pipes) &
\end{tabular} & \begin{tabular}{lcc} 
Slab, rimmed & \multicolumn{2}{l}{$25 \times 10^{3} \mathrm{kcal} / \mathrm{t}$-ingot } \\
Slab, killed & 82 &, \\
Billet, rimmed & 44 & $"$ \\
Billet, killed & 141 & $"$ \\
(for bars and pipes) &
\end{tabular} \\
\hline Hot strip & $\begin{array}{l}\mathrm{FR}=248 \times 10^{3} \mathrm{kcal} / \mathrm{t}-\mathrm{slab} \\
\mathrm{PR}=80 \mathrm{kWh} / \mathrm{t}-\mathrm{slab} \\
\mathrm{HDR}=6 \% ; \mathrm{HCR}=19 \% \\
\text { Fuel gas preheated }\end{array}$ & $\begin{array}{l}\mathrm{FR}=216 \times 10^{3} \mathrm{kcal} / \mathrm{t} \text {-slab } \\
\mathrm{PR}=82 \mathrm{kWh} / \mathrm{t} \text {-slab } \\
\mathrm{HCR}=40 \% \\
\text { Fuel preheating temp. up by } 100 \text { to } 550^{\circ} \mathrm{C} \\
\text { Extraction temp. down by } 30 \text { to } 1170^{\circ} \mathrm{G}\end{array}$ \\
\hline Plate & $\begin{array}{l}\mathrm{FR}=273 \times 10^{3} \mathrm{kcal} / \mathrm{t}-\mathrm{slab} \\
\mathrm{PR}=90 \mathrm{kWh} / \mathrm{t} \text {-slab } \\
\mathrm{HCR}=30 \% \\
\text { Fuel gas preheated }\end{array}$ & $\begin{array}{l}\mathrm{FR}=253 \times 10^{3} \mathrm{kcal} / \mathrm{t} \text {-slab } \\
\mathrm{PR}=92 \mathrm{kWh} / \mathrm{t} \text {-slab } \\
\mathrm{HCR}=40 \% \\
\text { Fuel preheating temp. up by } 100 \text { to } 550^{\circ} \mathrm{C} \\
\text { Extraction temp. down by } 30 \text { to } 1170^{\circ} \mathrm{C}\end{array}$ \\
\hline Bar & $\begin{array}{l}\mathrm{FR}=219 \times 10^{3} \mathrm{kcal} / \mathrm{t}-\mathrm{billet} \\
\mathrm{PR}=80 \mathrm{kWh} / \mathrm{t} \text {-billet } \\
\mathrm{HCR}=50 \% \\
\text { Fuel gas preheated }\end{array}$ & $\begin{array}{l}\mathrm{FR}=183 \times 10^{3} \mathrm{kcal} / \mathrm{t} \text {-billet } \\
\mathrm{PR}=82 \mathrm{kWh} / \mathrm{t} \text {-billet } \\
\mathrm{HCR}=70 \% \\
\text { Fuel preheating temp. up by } 200 \text { to } 500^{\circ} \mathrm{C} \\
\text { Extraction temp. down by } 30 \text { to } 1140^{\circ} \mathrm{C}\end{array}$ \\
\hline
\end{tabular}


Table 30. Energy/calory conversion table.

\begin{tabular}{l|c}
\hline & Calorific value rate \\
\hline Coking coal & $7700 \mathrm{kcal} / \mathrm{kg}$ \\
Coal for BF injection & $7250 \mathrm{kcal} / \mathrm{kg}$ \\
Coke & $7200 \mathrm{kcal} / \mathrm{kg}$ \\
Tar & $8650 \mathrm{kcal} / \mathrm{kg}$ \\
Oil for BF injection & $9200 \mathrm{kcal} / l$ \\
Grude light oil & $9720 \mathrm{kcal} / \mathrm{kg}^{3}$ \\
COG (STD base) & $4579 \mathrm{kcal} / \mathrm{Nm}^{3}$ \\
BFG (STD base) & $696 \mathrm{kcal} / \mathrm{Nm}^{3}$ \\
LDG (STD base) & $2000 \mathrm{kcal} / \mathrm{Nm}^{3}$ \\
Oxygen (STD base)* & $1715 \mathrm{kcal} / \mathrm{Nm}^{3}$ \\
Steam** & $800 \mathrm{kcal} / \mathrm{Nm}^{3}$ \\
Power (STD base) & $2450 \mathrm{kcal} / \mathrm{kWh}^{*}$ \\
\hline
\end{tabular}

* $\quad=0.7 \mathrm{kWh} / \mathrm{Nm}^{3} \times 2450 \mathrm{kcal} / \mathrm{kWh}$

** 10 ata, $200^{\circ} \mathrm{C}$, with a boiler efficiency $\eta_{\mathrm{B}}=85 \%$

Table 31. Distribution of byproduct gases.

\begin{tabular}{l|c|c}
\multicolumn{1}{c|}{ Apparatus } & Gases used & $\begin{array}{c}\mathrm{CV} \\
\left(\mathrm{kcal} / \mathrm{Nm}^{3}\right)\end{array}$ \\
\hline $\begin{array}{l}\text { Coke oven } \\
\text { BF hot stove }\end{array}$ & $\begin{array}{c}\text { BFG }+\mathrm{COG} \\
\mathrm{BFG}+\mathrm{COG}\end{array}$ & 1000 \\
1110 \\
\hline $\begin{array}{l}\text { Soaking furnace } \\
\text { Continuous heating furnace } \\
\text { Batch heating furnace }\end{array}$ & BFG+COG & 2500 \\
Lime calcination kiln & \\
\hline $\begin{array}{l}\text { Heat treatment furnaces* } \\
\text { Sinter igniter furnace } \\
\text { BOF and CG } \\
\text { Chemical processes, BF run- } \\
\text { ners, etc. }\end{array}$ & COG & $4579 * *$ \\
\hline Power boilers & $\begin{array}{l}\text { The rest of BFG and COG } \\
\text { and the whole of LDG }\end{array}$ \\
\hline
\end{tabular}

whereby the deficiency is to be purchased while the excess to be sold off. There is no citation of burners, boilers, capacities, number of equipment, etc., except the generation efficiency, which is $35.1 \%$ for STD and $36.6 \%$ for TGT, both the transformer outlet end rate. (ii) The BF Blower

The BF blowers are of the electric motor drive type, and the dehumitizer is the induction cooling type absorbing refrigerator.

(iii) The Oxygen Plant

The oxygen plant is to produce oxygen and nitrogen only, that is, no argon-making is planned. The $\mathrm{PR}$ is $0.7 \mathrm{kWh} / \mathrm{Nm}^{3}-\mathrm{O}_{2}$ at $\mathrm{STD}, 0.65$ at TGT.

(iv) The Process Steam

The process steam is to be made by an exclusive purpose boiler of efficiency $85 \%$ when STD, but in TGT, all of the steam is to be generated by recovered heat. The steam condition is 10 ata and $200{ }^{\circ} \mathrm{C}$.

(v) The Process Compressed Air

The air supply is source distributed, dual line system. The total requirement and the PR are $150 \mathrm{Nm}^{3}$ / t-crude steel at $0.1 \mathrm{kWh} / \mathrm{Nm}^{3}$ for $\mathrm{STD}$ and 140 at 0.09 for TGT.

(vi) Utilities for Other Sectors Including Administration and Control

The PR for water is $7 \mathrm{kWh} / \mathrm{t}$-crude steel, and other auxiliary requirements are for fuels $20 \times 10^{3} \mathrm{kcal} / \mathrm{t}$ crude steel, for power $5000 \mathrm{~kW}\left(3650 \times 10^{3} \mathrm{kWh} /\right.$ month), and for steam $10 \mathrm{t} / \mathrm{h}$ (7 $300 \mathrm{t} /$ month).

The heat recovery at TGT is to be done by the centralized power generation on an extraction mixed pressure condensing turbine system, which is also to supply the process steam through controlled steam extraction from the turbine as shown in Fig. 16.. The waste heat to be recovered in the TGT operation is from the 5 sources listed in Table 32.

* For plates and cold rolled products, ** STD base

Table 32. Waste heat recovery apparatuses for TGT.

\begin{tabular}{|c|c|c|}
\hline & Apparatus specifications & Steam generation and conditions \\
\hline $\begin{array}{l}\text { GDQ } \\
\text { coke sensible } \\
\text { heat recovery }\end{array}$ & $\begin{array}{l}\text { Coke production : } 254 \mathrm{kt} / \mathrm{month} \\
\text { Coke temps. ; charged at: } 1050^{\circ} \mathrm{C} \\
\text { discharged at : } 200^{\circ} \mathrm{C}\end{array}$ & $\begin{array}{l}\text { Steam generation : } 154 \mathrm{t} / \mathrm{h} \\
\text { Steam conditions : } 100 \text { ata, } 540{ }^{\circ} \mathrm{C} \\
\text { Power generation : } 38.8 \mathrm{MW} \text { (transformer end) } \\
\text { Net power generation rate : } 103 \mathrm{kWh} / \mathrm{t} \text {-coke or } \\
77 \mathrm{kWh} / \mathrm{t} \text {-coal }\end{array}$ \\
\hline $\begin{array}{l}\text { Sinter cooler } \\
\text { heat recovery }\end{array}$ & $\begin{array}{l}\text { Exhaust gas: } 9100 \mathrm{Nm}^{3} / \mathrm{min} \text { or } 500 \mathrm{Nm}^{3} / \mathrm{t} \text {-sinter } \\
\text { (each stack) } \\
\text { Heat recovery applied to the No. } 1 \text { stack only; } \\
\text { gas temp. : } 260^{\circ} \mathrm{C} \text {, and of the } 9100 \mathrm{Nm}^{3} \\
\text { a) } 1000 \mathrm{Nm}^{3} / \mathrm{min} \text { for combustion air preheating, } \\
\text { b) } 4300 \mathrm{Nm}^{3} / \mathrm{min} \text { for preheated sintering, and } \\
\text { c) } 3800 \mathrm{Nm}^{3} / \mathrm{min} \text { for steam generation }\end{array}$ & $\begin{array}{l}\text { Steam generation : } 16.9 \mathrm{t} / \mathrm{h} \text { or } 18 \mathrm{~kg} / \mathrm{t} \text {-sinter } \\
\text { Gas temps. : } 260 \text { to } 100^{\circ} \mathrm{G} \\
\text { Steam conditions : } 10 \text { ata, } 200^{\circ} \mathrm{C}\end{array}$ \\
\hline $\begin{array}{l}\text { BF slag } \\
\text { heat recovery }\end{array}$ & $\begin{array}{l}\text { Slag production: } 164.1 \mathrm{kt} / \mathrm{month} \text { or } 310 \mathrm{~kg} / \mathrm{t} \text {-pig } \\
\text { Heat: } 422 \times 10^{3} \mathrm{kcal} / \mathrm{t} \text {-slag }\end{array}$ & $\begin{array}{l}\text { Steam generation : } 75 \mathrm{t} / \mathrm{h} \\
\text { Steam conditions : } 40 \text { ata, } 430^{\circ} \mathrm{C}\end{array}$ \\
\hline $\begin{array}{l}\text { BOF OG sensible } \\
\text { heat recovery }\end{array}$ & & Steam generation : $44 \mathrm{t} / \mathrm{h}$ or $60 \mathrm{~kg} / \mathrm{t}$-steel \\
\hline $\begin{array}{l}\text { Soaking pit waste } \\
\text { gas heat recovery }\end{array}$ & Exhaust gas : $96 \mathrm{Nm}^{3} / \mathrm{t}$-ingot & $\begin{array}{l}\text { Steam generation : } 3 \mathrm{t} / \mathrm{h} \text { or } 12 \mathrm{~kg} / \mathrm{t} \text {-ingot } \\
\text { Steam conditions : } 10 \text { ata, } 200^{\circ} \mathrm{C}\end{array}$ \\
\hline
\end{tabular}




\section{Energy Balance in STD and TGT Operations}

The results of calculations are summarized in Table 33 and Fig. 17. It will be seen that in the STD, the dependence of this Model Works on coal is $92 \%$, and the whole of the fuels for heating and coking and $79 \%$ of the power is met with by the byproduct gases and the recovered power. In the TGT, on the other hand, not only all the necessary fuels, power and steam is supplied on the byproduct gases, but some 36 million $\mathrm{kWh}$ of electricity can be sold off to outside.

The per tonnage crude steel energy rate is $5175 \times$ $10^{3} \mathrm{kcal} / \mathrm{t}$ in the STD and $4696 \times 10^{3} \mathrm{kcal} / \mathrm{t}$ for TGT, a further decrease of remarkable $9.3 \%$.

\section{Effects of Operation Variations on $S T D$}

As the energy of any integrated steel works is utilized as in an integral system, variations of any one of the processes can affect the total energy balance. Of various variations discussed in Chapter III, the BF oil rate (OR), the volatile matter percentage of the coking coal (VM), and the continuous casting ratio (CGR) are considered as particularly efficatious.

(1) Variation in OR

The BF operation conditions of Table 11 were applied to three cases of (a) $\mathrm{OR}=35 \mathrm{~kg} / \mathrm{t}$, (b) $\mathrm{OR}=$

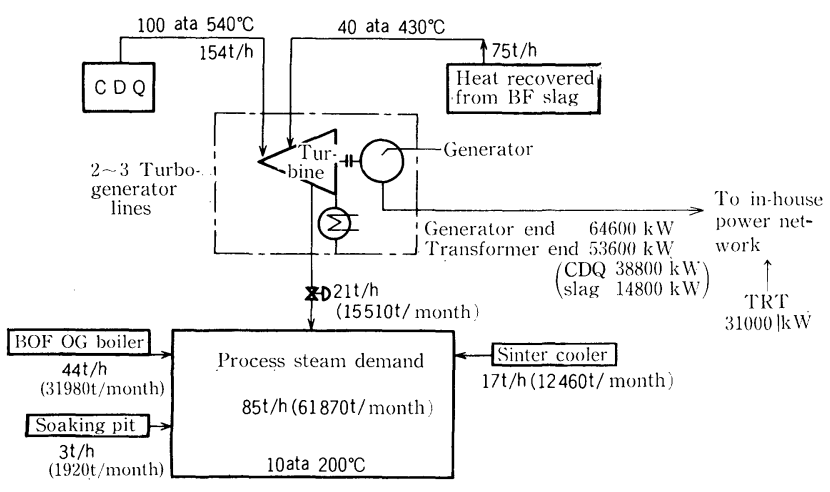

Fig. 16. Waste heat recovery flow.
$17 \mathrm{~kg} / \mathrm{t}$, and (c) all coke. The results are shown in Table 34 and Fig. 18. The decrease of OR, hence the increase of $\mathrm{CR}$ (coke rate), makes the purchased power to become less, though the energy rate to become greater.

(2) Variation in VM

As examined in Chatper III, the Cokemaking Sector, any change in VM affects, through its effects on coke yield, COG generation rate, hence through changes in coking coal requirement and quantity of $\mathrm{COG}$, on the requirement of power generation auxiliary fuel and others. The results of calculation conducted for three cases of VMs 25, 27, and $29 \%$ (i.e., VM=27 $\pm 2 \%$ ) are shown in Tables 35 and 36, and in Fig. 19.

To summarize, the effects of changes in VM by $\pm 2 \%$ on the energy balance are as follows;

$$
\begin{array}{ll}
\text { Coal rate } & 640 \pm 16 \mathrm{~kg} / \mathrm{t} \text {-pig } \\
\begin{array}{l}
\text { Auxiliary } \\
\text { energies }
\end{array} & 225 \mp 39 \times 10^{3} \mathrm{kcal} / \mathrm{t} \text {-crude steel } \\
\begin{array}{l}
\text { Salable } \\
\text { energies* }
\end{array} & 277 \mp 23 \times 10^{3} \mathrm{kcal} / \mathrm{t} \text {-crude steel } \\
\begin{array}{l}
\text { Energy rate } \\
* \text { tar and others }
\end{array} & 5175 \mp 38 \times 10^{3} \mathrm{kcal} / \mathrm{t} \text {-crude steel } \\
&
\end{array}
$$

\section{(3) GCR}

The increase in GCR has a great effect on energy saving by eliminating the ingotmaking process and improving the yield. The evaluation of this energy saving, however, cannot be done in a straightforward manner because the conventional expression of energy rate per ton of crude steel cannot well cover the cases when materials balance is changed due to changes in the ratio of crude steel to products and in the ratio of

\begin{tabular}{|c|c|c|c|c|c|c|c|}
\hline & & \multicolumn{3}{|c|}{ STD } & \multicolumn{3}{|c|}{ TGT } \\
\hline & & $\begin{array}{l}\text { Monthly } \\
\text { transaction }\end{array}$ & $\begin{array}{l}\text { Calorific } \\
\text { value } \\
\left(10^{9} \mathrm{kcal}\right)\end{array}$ & $\%$ & $\begin{array}{l}\text { Monthly } \\
\text { transaction }\end{array}$ & $\begin{array}{c}\text { Calorific } \\
\text { value } \\
\left(10^{9} \mathrm{kcal}\right)\end{array}$ & $\%$ \\
\hline \multirow{4}{*}{ Purchased } & Coking coal (t/month) & 338500 & 2606.5 & 89.7 & 334500 & 2575.7 & 93.4 \\
\hline & Injection oil $(l /$ month $)$ & 19700 & 181.2 & 6.2 & 19700 & 181.2 & 6.6 \\
\hline & Power $\left(10^{3} \mathrm{kWh} /\right.$ month $)$ & 48332 & 118.4 & 4.1 & - & - & - \\
\hline & Sum & & 2906.1 & & & 2756.9 & \\
\hline \multirow{5}{*}{ Sold off } & Coke breeze (t/month) & 2500 & 18.0 & & 5800 & 41.2 & \\
\hline & $\operatorname{Tar}(\mathrm{t} / \mathrm{month})$ & 12200 & 105.4 & & 12000 & 104.2 & \\
\hline & Crude light oil ( $\mathrm{t} /$ month) & 2500 & 24.5 & & 2500 & 24.1 & \\
\hline & Power $\left(10^{3} \mathrm{kWh} /\right.$ month $)$ & - & - & & 36000 & 84.6 & \\
\hline & Sum & & 147.9 & $5.1^{*}$ & & 254.1 & $9.2^{*}$ \\
\hline \multicolumn{2}{|c|}{ Net input $\left(10^{9} \mathrm{kcal} /\right.$ month $)$} & \multicolumn{3}{|c|}{2758.2} & \multicolumn{3}{|c|}{2502.8} \\
\hline \multirow{2}{*}{\multicolumn{2}{|c|}{$\begin{array}{l}\text { Energy rate }\left(10^{3} \mathrm{kcal} / \mathrm{t} \text {-crude steel }\right) \\
\text { Energy rate }\left(10^{3} \mathrm{kcal} / \mathrm{t} \text {-product }\right)\end{array}$}} & \multirow{2}{*}{\multicolumn{3}{|c|}{$\begin{array}{l}5175 \\
5606\end{array}$}} & \multicolumn{3}{|c|}{4696} \\
\hline & & & & & & 5087 & \\
\hline
\end{tabular}
return scrap to purchased scrap. Therefore, the appreciation was done here on the basis of per tonnage product energy rate with both the purchased scrap and the products fixed.

Thus, calculations were made on the basis of the

Table 33. Energy balance and energy rates for STD and TGT.

* Percentage as of the purchased 

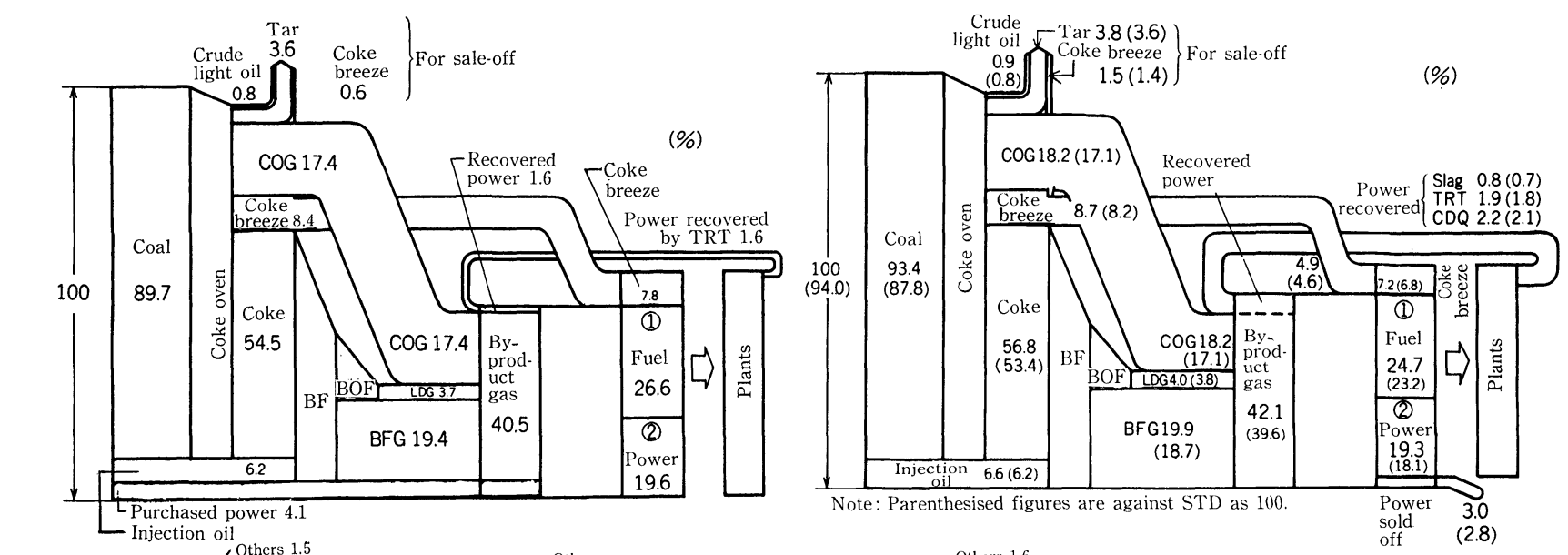

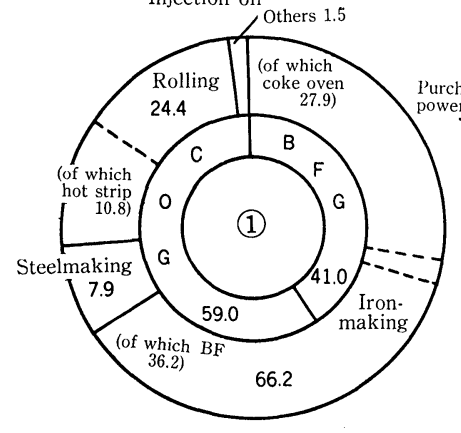

(1) Fuels for heating and carbonization $722.2 \times 10^{9} \mathrm{kcal} / \mathrm{month}$

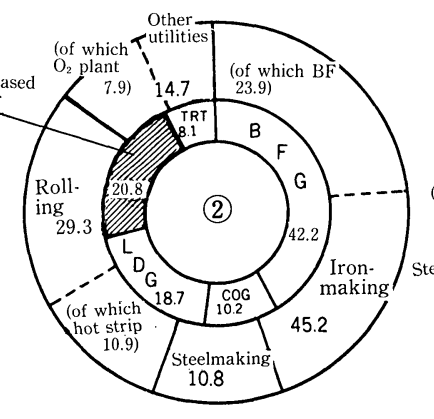

(2) Power

$232.5 \times 10^{6} \mathrm{kWh} /$ month

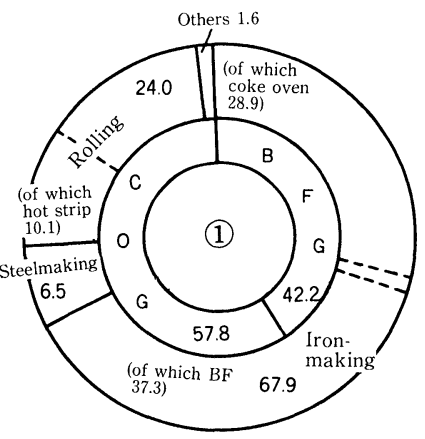

(1) Fuels for heating and carbonization $678.7 \times 10^{4} \mathrm{kcal} / \mathrm{month}$

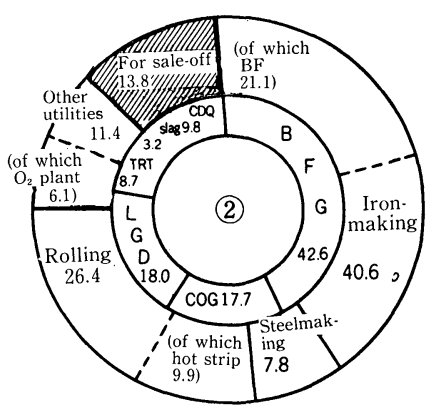

(2) Power; 261.5 (of which inhouse consumption, $225.5 \times$ $10^{6} \mathrm{kWh} /$ month)

Fig. 17. Energy balance flow and fuel-power consumption balance in STD operation (left) and in TGT operation (right).

Table 34. Changes in energy structure according to change of $\mathrm{BF}$ oil rate.

\begin{tabular}{|c|c|c|c|c|}
\hline & Oil rate $(\mathrm{kg} / \mathrm{t})$ & 35 & 17 & 0 \\
\hline & Coking coal (kt/month) & 338.5 & 360.5 & 384.6 \\
\hline & Injection oil (k $l /$ month) & 19.7 & 9.6 & 0 \\
\hline & Power $\left(10^{6} \mathrm{kWh} /\right.$ month $)$ & 48.3 & 37.2 & 33.3 \\
\hline & Sum & 2906.1 & 2955.2 & 3033.0 \\
\hline & Coke & 2.5 & 4.6 & 7.0 \\
\hline & Tar (kt/month) & 12.2 & 13.0 & 13.8 \\
\hline Sold off & Crude light oil (kt/month) & 2.5 & 2.7 & 2.9 \\
\hline & Power $\left(10^{6} \mathrm{kWh} / \mathrm{mon}\right.$ & 0 & 0 & 0 \\
\hline & Sum in $10^{9} \mathrm{kcal} / \mathrm{month}$ & 147.9 & 171.3 & 198.0 \\
\hline $\mathrm{Net}$ & ut $\left(10^{9} \mathrm{kcal} / \mathrm{month}\right)$ & 2 & 2783.9 & 2835.0 \\
\hline Energ & 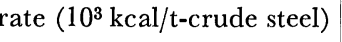 & 5175 & 5223 & 5319 \\
\hline
\end{tabular}

examination presented in Chapter III, the Steelmaking Sector, for a monthly output of slabs and billets set at 436 and $78 \mathrm{kt}$, respectively, and the GGR varied from 70 to $80 \%$ as shown in Fig. 20. Here, the decrement in the in-house return scrap due to improved yield is assumed to be compensated for by appropriately changing the converter charge mix (e.g., increasing the HMR (hot metal rate)) to give rise to the predetermined quantities of products and

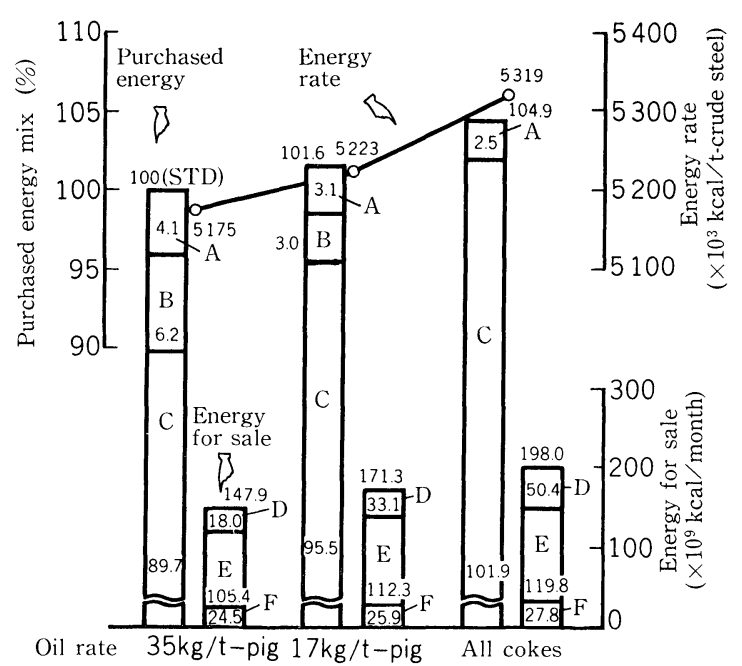
A: Purchased power
D: Energy for sale
B: Oil
E: Coke fines
G: Coal
F: Crude light oil

Fig. 18. Changes in energy balance according to change of $\mathrm{BF}$ oil rate.

purchased scrap. It will be seen in Table 37 and Fig. 20 that the results are that a $10 \%$ raise in the CGR means an increase in the crude steel energy rate by $19 \times 10^{3} \mathrm{kcal} / \mathrm{t}$, but a decrease in the products energy rate by $42 \times 10^{3} \mathrm{kcal} / \mathrm{t}$. 
Table 35. Changes in coke oven operation parameters according to change of VM.

\begin{tabular}{|c|c|c|c|c|}
\hline $\mathrm{VM}(\%)$ & 25 & 27 (STD) & 29 & Notes \\
\hline Lump coke needed (kt/month) & 220.0 & 220.0 & 220.0 & TR and GR constant \\
\hline Coking coke needed ( $\mathrm{kt} / \mathrm{month}$ ) & 330.3 & 338.5 & 347.0 & \\
\hline Gross yield (\%) & 76.7 & 75.0 & 73.3 & $=-0.85 \mathrm{VM}+99.1$ \\
\hline Lump coke yield (\%) & 66.6 & 65.0 & 63.4 & $=-0.80 \mathrm{VM}+86.5$ \\
\hline GUR (\%) & 97.5 & 100.0 & 102.5 & \\
\hline Tar recovery rate $(\mathrm{kg} / \mathrm{t})$ & 30.4 & 36.0 & 41.6 & $=2.8 \mathrm{VM}-39.6$ \\
\hline COG recovery rate $\left(\mathrm{Nm}^{3} / \mathrm{t}\right)$ & 314.5 & 327.0 & 339.6 & $=6.0 \mathrm{VM}+150$ \\
\hline Coking fuel $\left(10^{3} \mathrm{kcal} / \mathrm{t}\right)$ & 561.6 & 576.0 & 590.4 & $=0.245 \mathrm{GUR}+33.1$ \\
\hline
\end{tabular}

Table 36. Changes in energy structure according to change of VM.

\begin{tabular}{|c|c|c|c|c|}
\hline \multicolumn{2}{|r|}{$\mathrm{VM}(\%)$} & 25 & 27 (STD) & 29 \\
\hline \multirow{4}{*}{$\begin{array}{l}\text { Pur- } \\
\text { chased }\end{array}$} & Coking coal (kt/month) & 330.3 & 338.5 & 347.0 \\
\hline & Injection oil (kl/month) & 19.7 & 19.7 & 19.7 \\
\hline & Power $\left(10^{6} \mathrm{kcal} /\right.$ month $)$ & 56.8 & 48.3 & 39.8 \\
\hline & Sum in $10^{9} \mathrm{kcal} / \mathrm{month}$ & 2863.7 & 2906.1 & 2950.6 \\
\hline \multirow{4}{*}{ Sold off } & Coke breeze (kt/month) & 2.0 & 2.5 & 3.0 \\
\hline & Tar (kt/month) & 10.1 & 12.2 & 14.5 \\
\hline & Crude light oil (kt/month) & 2.5 & 2.5 & 2.6 \\
\hline & Sum in $10^{9} \mathrm{kcal} / \mathrm{month}$ & 126.1 & 147.9 & 172.3 \\
\hline \multicolumn{2}{|c|}{ Net input $\left(10^{9} \mathrm{kcal} / \mathrm{month}\right)$} & 2737.6 & 2758.2 & 2778.3 \\
\hline \multicolumn{2}{|c|}{ Energy rate $\left(10^{3} \mathrm{kcal} / \mathrm{t}\right.$-crude steel $)$} & 5136 & 5175 & 5213 \\
\hline
\end{tabular}

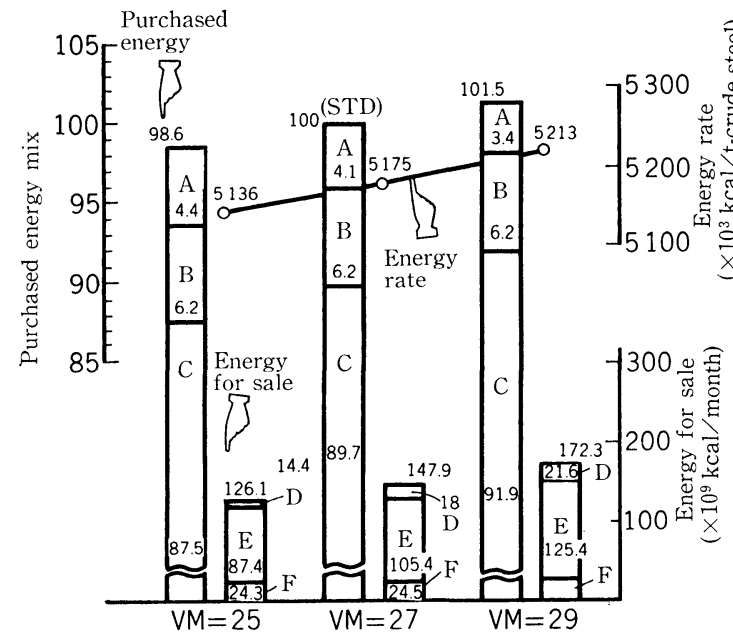
A: Purchased power
D: Coke breeze
B: Oil
E: Tar
C: Coal
F: Crude light oil

Fig. 19. Changes in energy balance according to change of VM.

\section{Examination of Self-sufficiency Energy Balance on TGT Operation}

As discussed in Section IV. 1, in the event of TGT operation, not only all the fuels and power except the oil for BF injection can be supplied on the byproduct energies, but a considerable amount of energy will be had as excess. Further, if the all coke operation is practiced, the excess will become even greater as
Table 37. Effects of changes in GCR on energy rate and heat balance.

\begin{tabular}{|c|c|c|c|c|}
\hline & GCR (\%) & $\begin{array}{c}70 \% \\
\text { (STD) }\end{array}$ & $80 \%$ & $\begin{array}{l}\text { Differ- } \\
\text { ence }\end{array}$ \\
\hline \multicolumn{2}{|c|}{ Energy rate $\left(10^{3} \mathrm{kcal} / \mathrm{t}\right.$-crude steel $)$} & 5175 & 5194 & +19 \\
\hline \multicolumn{2}{|c|}{ Energy rate $\left(10^{3} \mathrm{kcal} / \mathrm{t}\right.$-product $)$} & 5606 & 5564 & -42 \\
\hline \multicolumn{2}{|c|}{ Crude steel throughput (kt/month) } & 533 & 527 & -6 \\
\hline \multicolumn{2}{|c|}{ Product throughput (kt/month) } & 492 & 492 & 0 \\
\hline \multirow{4}{*}{$\begin{array}{l}\text { Pur- } \\
\text { chased }\end{array}$} & Coking coal (kt/month) & 338.5 & 336.9 & \\
\hline & Injection oil (k $l /$ month) & 19.7 & 19.65 & \\
\hline & Power $\left(10^{6} \mathrm{kWh} /\right.$ month $)$ & 48.3 & 45.5 & \\
\hline & Sum in $10^{9} \mathrm{kcal} / \mathrm{month}$ & 2906.1 & 2886.4 & -19.7 \\
\hline \multirow{4}{*}{ Sold off } & Goke breeze (kt/month) & 2.5 & 2.8 & \\
\hline & Tar (kt/month) & 12.2 & 12.1 & \\
\hline & Grude light oil (kt/month) & 2.5 & 2.5 & \\
\hline & Sum in $10^{9} \mathrm{kcal} /$ month & 147.8 & 149.1 & +1.3 \\
\hline \multicolumn{2}{|c|}{ Total in $10^{9} \mathrm{kcal} / \mathrm{month}$} & 2758.3 & 2737.3 & -21.0 \\
\hline
\end{tabular}

shown in Tables 38 and 39.

This excess energy can be sold off in a form of gas, electricity or steam intending for neighboring firms or for general consumers, but here two cases of self-sufficient utilization are examined in terms of injection of pulverized coal or COG into the BF. The results are shown in Table 39 and in Fig. 21. It will be seen that in all those cases a large portion of the excess energy can be absorbed while reducing the energy rate considerably.

\section{Dynamic Management of Energy Demand/ Supply}

For any integrated steel works, the byproduct gases are hard to utilize because their generation and consumption are irregular and because they are difficult to store by nature. In the past, the steel works used to counteract those difficulties simply by resorting to oil and by purchasing power, and it was indeed due to the function of adjusting the demand and supply of those energies that not only the stable supply of energy was ensured whenever and wherever it was needed, but the values of byproduct gases were raised.

As discussed in Chapter IV, however, when the energy saving is progressed so extensively as to the TGT, divorcing of oil will have been realized and a considerable amount of salable excess energy will be had 
$\langle$ Material flow for $\rangle$

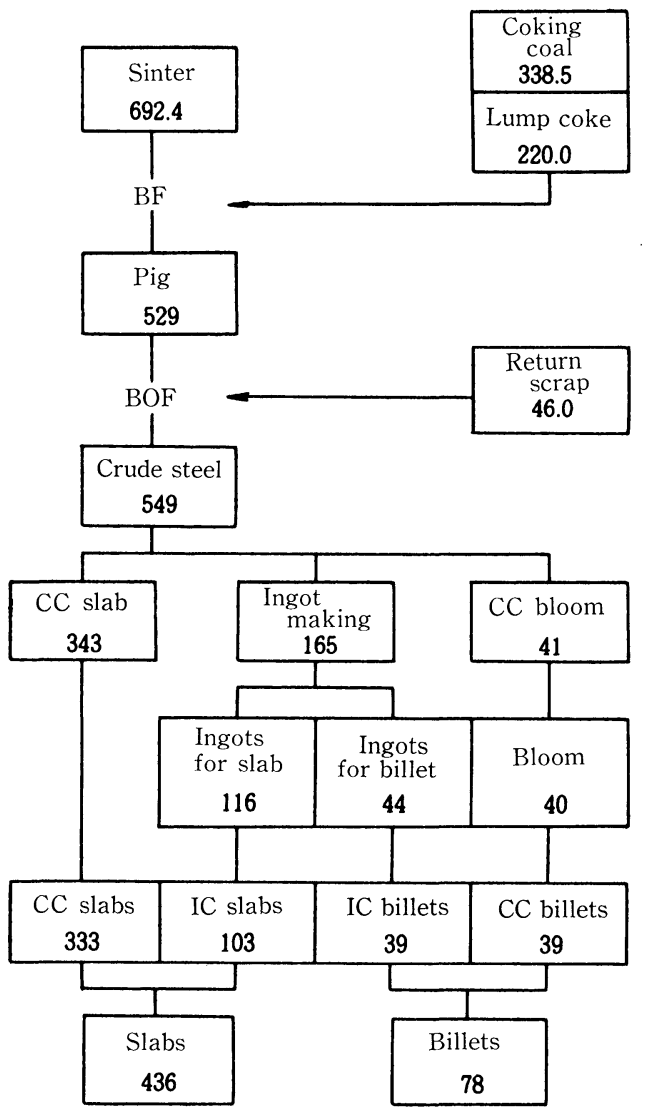

Material flow for

CCR of $80 \%$

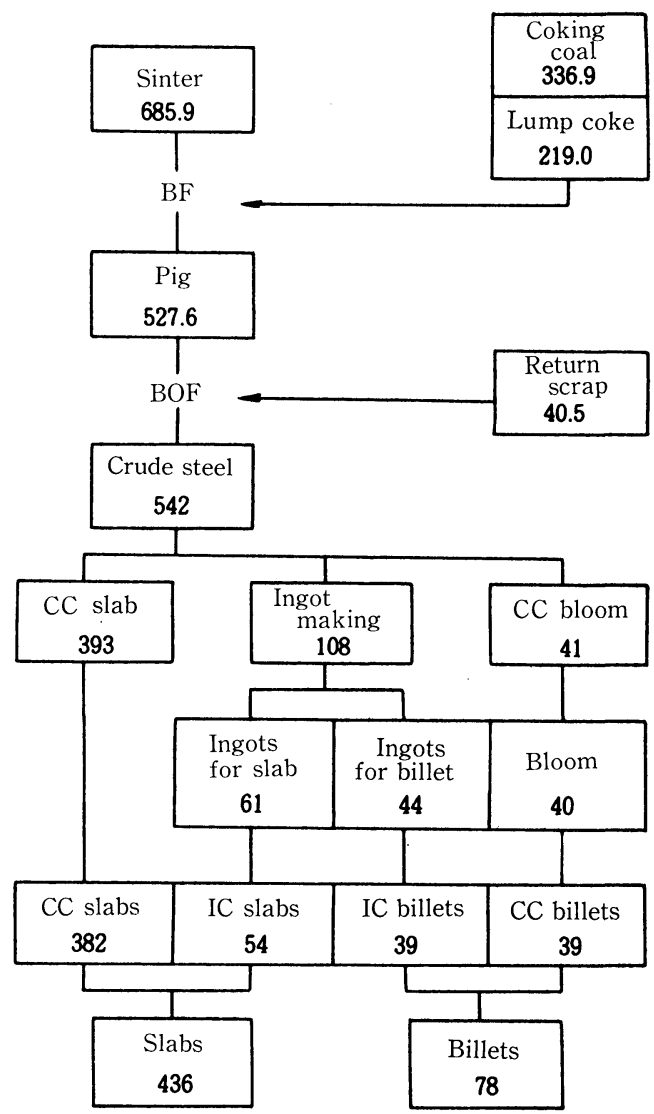

Fig. 20.

Material flow for CCRs of $70 \%$ (left) and $80 \%$ (right).

Table 38. Changes in operation parameters according to change of BF fuel.

\begin{tabular}{|c|c|c|c|c|c|}
\hline & & $\begin{array}{c}\text { TGT } \\
\mathrm{OR}=35 \mathrm{~kg} / \mathrm{t}\end{array}$ & All coke & $\begin{array}{c}\text { COG } \\
\text { injection }\end{array}$ & $\begin{array}{l}\text { Pulverized coal } \\
\text { injection }\end{array}$ \\
\hline \multirow{11}{*}{ Blast furnace } & FR (kt/t-pig) & 446 & 468.2 & 454 & 454 \\
\hline & GR (kt/t-pig) & 411 & 468.2 & 429.1 & 399.1 \\
\hline & Injection fuel rate ( $\mathrm{kg} / \mathrm{t}-\mathrm{pig})$ & 35 & 0 & $24.9 *$ & 54.6 \\
\hline & Blast volume rate $\left(\mathrm{Nm}^{3} / \mathrm{t}\right.$-pig $)$ & 1050 & 1121 & 1036 & 1035 \\
\hline & BFG generated $\left(\mathrm{Nm}^{3} / \mathrm{t}-\right.$ pig $)$ & 1518 & 1591 & 1545 & 1503 \\
\hline & $\mathrm{BFG}$ calorific value $\left(\mathrm{kcal} / \mathrm{Nm}^{3}\right)$ & 685 & 661 & 693 & 677 \\
\hline & $\mathrm{CO}$ efficiency, $\eta_{\mathrm{CO}}(\%)$ & 52.1 & 51.6 & 52.0 & 52.8 \\
\hline & Blast temp. $\left({ }^{\circ} \mathbf{C}\right)$ & 1315 & 1120 & 1315 & 1315 \\
\hline & Blast humidity $\left(\mathrm{g} / \mathrm{Nm}^{3}\right)$ & 6 & 6 & 6 & 6 \\
\hline & Tuyere front temp. $\left({ }^{\circ} \mathbf{C}\right)$ & 2463 & 2462 & 2458 & 2463 \\
\hline & Slag rate $(\mathrm{kg} / \mathrm{t}-\mathrm{pig})$ & 310 & 313 & 310 & 310 \\
\hline \multirow{2}{*}{ Hot stove } & Gas calorific value $\left(\mathrm{kcal} / \mathrm{Nm}^{3}\right)$ & 1116 & 811 & 1129 & 1129 \\
\hline & FR $\left(10^{3} \mathrm{kcal} / \mathrm{t}-\mathrm{pig}\right)$ & 471 & 421 & 464 & 464 \\
\hline \multicolumn{2}{|c|}{ TRT power generation $(\mathrm{kWh} / \mathrm{t}$-pig) } & 42.7 & 44.8 & 43.5 & 42.3 \\
\hline \multirow{3}{*}{ Coke oven } & Lump coke required (kt/month) & 217.4 & 247.7 & 227.0 & 211.3 \\
\hline & Coking coal required (kt/month) & 334.5 & 381.0 & 349.2 & 325.1 \\
\hline & Coke oven GUR (\%) & 98.8 & 112.0 & 103.2 & 96.0 \\
\hline
\end{tabular}

\section{* $50.7 \mathrm{Nm}^{3} / \mathrm{t}$-pig}

in hand. When the all coke operation is fully implemented, moreover, this trend will become much more apparent. This means that the in toto management and effective utilization of energy when produced in excess must be intensified through the whole of a steel works. As to how to achieve this end, greatly varying arguments and opinions were expressed in the Committee meetings, but all appeared to converge on 
Table 39. Changes in energy structure according to change of BF operation mode.

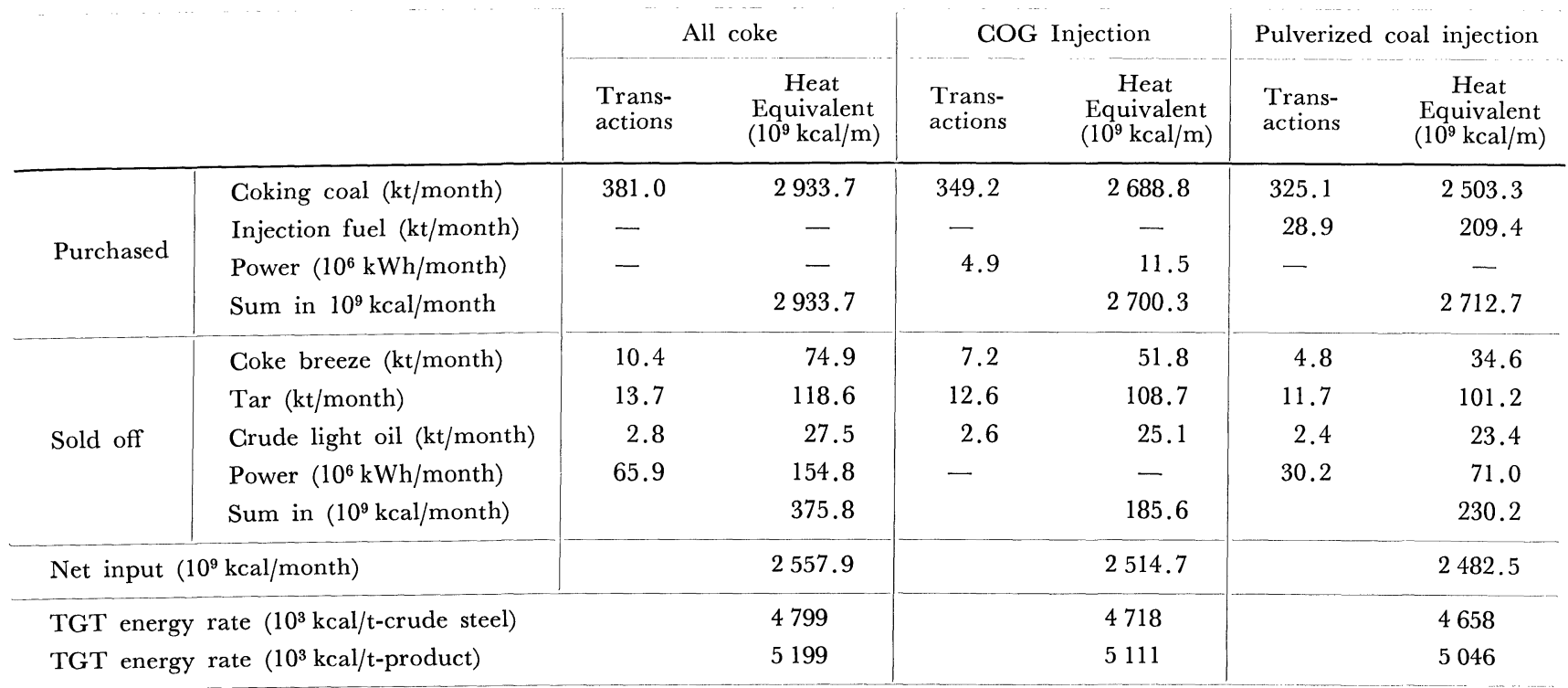
A: Purchased power
B: Oil
C: Coking coal
D: Fuel coal

$\begin{array}{ll}\text { E: } & \text { Power } \\ \text { F: } & \text { Breeze } \\ \text { G: } & \text { Tar } \\ \text { H: } & \text { Crude light oil }\end{array}$

Fig. 21.

Changes in energy balance according to change of $\mathrm{BF}$ operation practice on TGT base.

how to minimize the energy cost.

For this, three prerequisites of " decreasing energy consumption", "selecting cheaper energies", and "supplying energies stably" appear to be natural. However, the problems here are:

1) how to supply which byproduct gas to which apparatus with what GV?;

2) how best should the demand and supply be adjusted?;

3) in what form the power equipment, namely, the energy converters, should best be?;

4) how to recover and convert the waste energy and where to apply it?; and

5) how to deal with the excess energy?

Here, several concrete examples are introduced and discussed.

\section{Utilization of Byproduct Gases}

No unified conclusions have been reached as to how best the byproduct gases should be utilized. Instead, there appears to be two schools of thought for this proposition. Namely:

(1) One school has it that high GV fuels should be

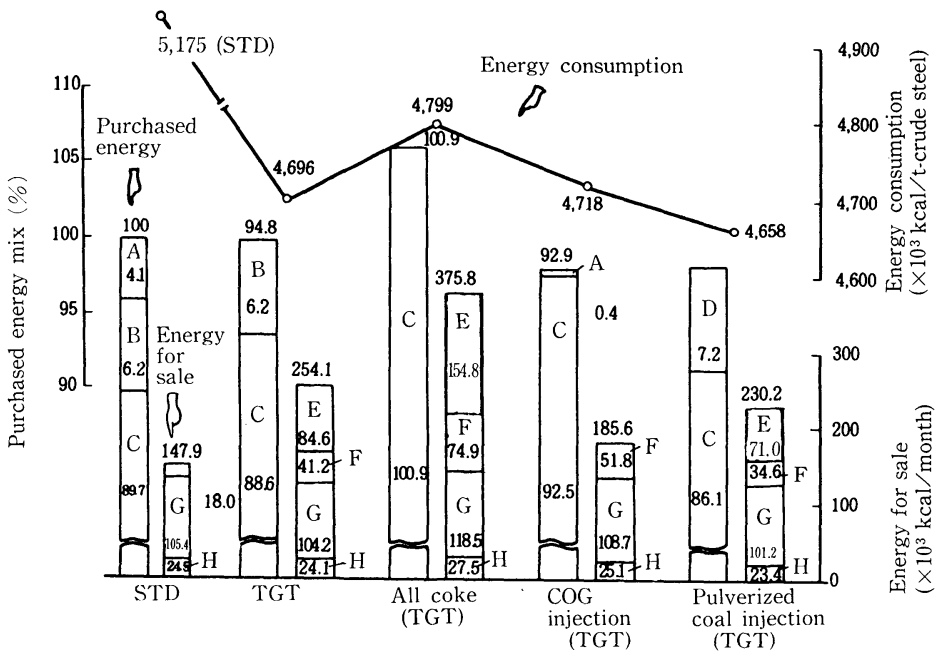

preferentially supplied to equipment that need high temperatures. That is, the high GV GOG is to be burnt at the reheating furnaces, while the low $\mathrm{CV}$ BFG is sent to the boilers. The merit of this method is that a high thermal efficiency and a high dispensability are obtained without investing much on the facility, and that much may be saved in the per CV energy transportation cost. The shortcomings are, on the other hand, that this method lacks the flexibility to take a fuel that happens to be available, and that it is not well adaptable to changing energy situation.

(2) The other is to try to utilize any low CV fuels at any and all thermal apparatuses by developing the necessary technologies. The use of $\mathbf{M}$ gases for coke ovens, hot stoves, and reheating furnaces is a realization of this notion.

Generally, the first is the easier for immediate adoption, for it is easy to see that this one gives better thermal efficiency. However, it is to be kept in mind that the above statement is valid only when the equipment remains identically the same. That same thermal efficiency can be realized for the same apparatus by changing the equipment appropriately is harder 


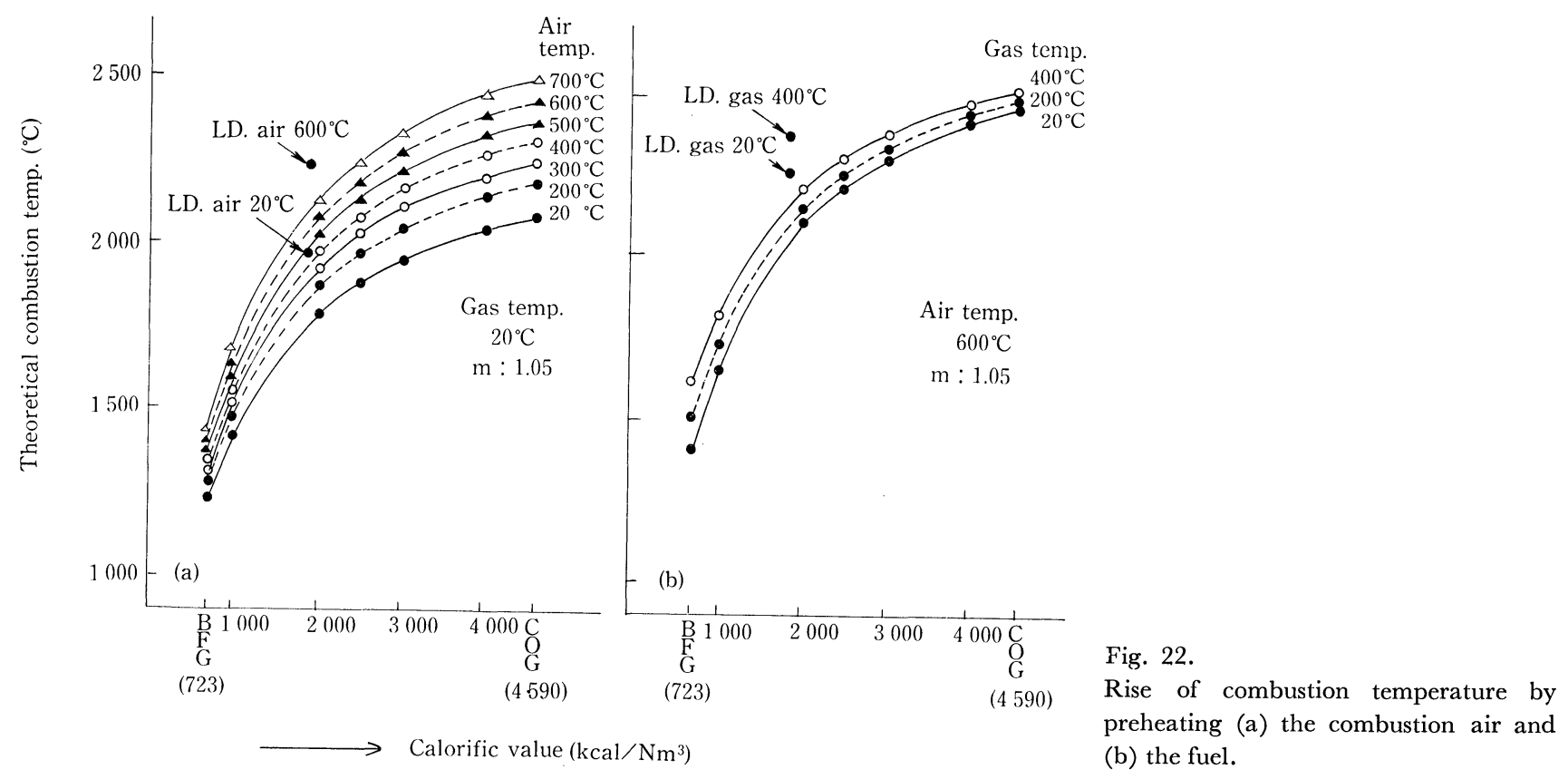

to conceive, but it is true enough. This is shown in Fig. 22 by means of relationships between the CVs of $\mathrm{COG}, \mathrm{BFG}$, and $\mathrm{M}$ gas and the theoretical combustion gas temperatures for an excess air rate $m$ of 1.05 .

The effects of preheating the combustion air are presented in Fig. 22(a). Even if the fuel gas is not preheated, considerable rise of combustion gas temperature may be obtained. Thus:

$\begin{array}{lrrrrrr}\quad \text { Fuel gas } & & \text { BFG } & \text { COG } & \text { M gas* } & \text { LDG** } \\ \text { Combustion air } & 20 & 1220 & 2070 & 1870 & 1970 \\ \text { Preheating } & 600 & 1390 & 2430 & 2190 & 2230 \\ \quad \text { temperature } & & & & & \\ \quad\left({ }^{\circ} \text { ) }\right) & & & & & \\ * 2500 \mathrm{kcal} / \mathrm{Nm}^{3} \text {; ** } & 1920 \mathrm{kcal} / \mathrm{Nm}^{3}\end{array}$

It is to be noted above that even with an $\mathrm{M}$ gas a combustion temperature over $2000^{\circ} \mathrm{C}$ is readily attainable.

The effects of preheating both the combustion air and the fuel gas may be seen in Fig. 22(b), where the air temperature is $600^{\circ} \mathrm{C}$. Thus, when the air temperature is $600{ }^{\circ} \mathrm{C}$ and fuel temperature is $400{ }^{\circ} \mathrm{C}$ :

$\begin{array}{lrrrr}\text { Fuel gas } & \text { BFG } & \text { COG } & \text { M gas* } & \text { LDG** } \\ \text { Theoretical } & 1590 & 2490 & 2270 & 2350 \\ \text { combustion gas } & & & & \\ \text { temperature }\left({ }^{\circ} \mathrm{C}\right) & \\ * 2500 \mathrm{kcal} / \mathrm{Nm}^{3} ; * * & 1920 \mathrm{kcal} / \mathrm{Nm}^{3}\end{array}$

It will be noticed here that larger effect is had by lower $\mathrm{CV}$ gases. For example, the rise in the theoretical combustion gas tmeperature with air preheated to $600{ }^{\circ} \mathrm{C}$ and fuel gas from 20 to $400{ }^{\circ} \mathrm{C}$ is $200{ }^{\circ} \mathrm{C}$ for $\mathrm{BFG}, 60^{\circ} \mathrm{C}$ for $\mathrm{COG}$, and $80^{\circ} \mathrm{C}$ for $\mathrm{M}$ gas.

As may be judged from above, the making of an $\mathrm{M}$ gas out of low CV BFG by adding COG and the preheating of combustion air and fuel gas is to make the low grade gas usable for high temperature apparatuses. This means that the value of low grade fuel has been elevated, and that, at a certain expense to be made on equipment to raise the thermal efficiency, better energy balance and better adaptability to changes in energy situation will be ensured. Furthermore, as a side effect, by adjusting the $\mathrm{CV}$ of $\mathrm{M}$ gas properly, generation of NOx is minimized and life of refractories prolonged because the temperature is held to the lowest necessary level.

Naturally, the utilization of byproduct gases must be contemplated, besides from the heat technology view points like above, from various other angles such as layout of facilities of generation and consumption, restrictions on demand/supply management, possibilities of future value-adding (for example, sales, extraction of pure $\mathrm{H}_{2}$ and $\mathrm{CO}$, application of $\mathrm{C}_{1}$ chemistry,* etc.), environmental protection, and safety.

Thus, the first of the five problems set forth earlier, that of "how the CV of a fuel should be?" is, as far as the thermal efficiency can be adjusted to the same level, neither very important nor very independent. It is no more than one of those many factors mentioned just above that are to be considered in building up a system of minimum energy cost. What will be needed henceforth are the proper appreciation of the cost of byproduct gases, development of method of efficiently burning low grade gases, and development of technology to add more value to those gases.

\section{Adjustment of Demand/Supply Gap}

An excess gas can be used either directly as fuel and as chemical raw material or indirectly as electricity or steam intended for neighboring communities (Table 40). As the generation of those byproduct

* Pronounced "G-one-chemistry", this term designates a future prospect (gaining supporters in Japan) of making such mono-carbon (or, C-sub-one) compounds, as $\mathrm{C}, \mathrm{CO}, \mathrm{CO}_{2}$ the raw materials for higher order C-one chemicals like $\mathrm{CH}_{4}$ and $\mathrm{CH}_{3} \mathrm{OH}$, on which new organic chemistry industry may be founded. 
Table 40. Various ways of excess energy utilization outside the steel works.

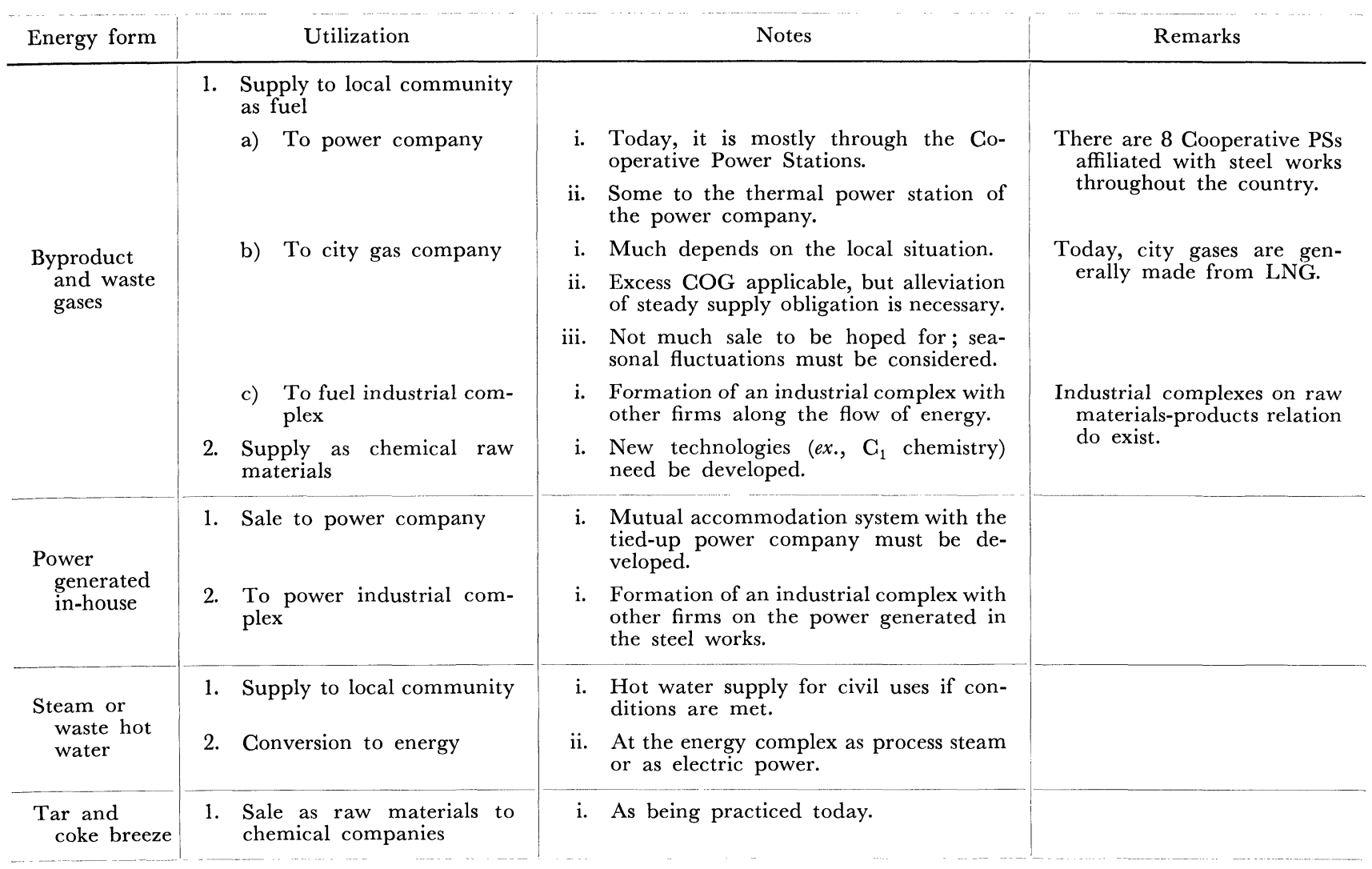

Table 41. TGT hourly gas balance (excluding the energy for power generation).

\begin{tabular}{|c|c|c|c|c|c|c|c|c|c|}
\hline \multirow{2}{*}{ Gases } & \multicolumn{3}{|c|}{ Normal operation } & \multicolumn{3}{|c|}{ One BF banked } & \multicolumn{3}{|c|}{ Hot strip line shut down } \\
\hline & BFG & GOG & LDG & BFG & COG & LDG & BFG & COG & LDG \\
\hline Generated $\left(10^{3} \mathrm{Nm}^{3} / \mathrm{h}\right)$ & 1133 & 152 & 77 & 567 & 152 & 77 & 1133 & 152 & 77 \\
\hline Consumed $\left(10^{3} \mathrm{Nm}^{3} / \mathrm{h}\right)$ & 581 & 123 & 0 & 304 & 89 & 0 & 558 & 104 & 0 \\
\hline Excess $\left(10^{3} \mathrm{Nm}^{3} / \mathrm{h}\right)$ & 552 & 29 & 77 & 263 & 63 & 77 & 575 & 48 & 77 \\
\hline $\begin{array}{l}\text { Excess energy* } \\
\text { in } 10^{6} \mathrm{kcal} / \mathrm{h} \\
\text { in } \mathrm{MW}\end{array}$ & & $\begin{array}{l}660 \\
281\end{array}$ & & & $\begin{array}{l}622 \\
265\end{array}$ & & & $\begin{array}{l}768 \\
327\end{array}$ & \\
\hline
\end{tabular}

* Variation is $c a .22 \%$ of the "normal".

gases fluctuates according to the state of operation, and because sale to outside generally prerequsites stable supply, the utilization of those gases need be considered both from the uses and from the demand/ supply adjustment.

\section{Management of Excess Gas}

The adjustment of gas demand/supply is being done by hours, by days and weeks, and by months or longer terms as follows:

1) by hours; switching-over of fuel gas to be done at gas holders and at boilers,

2) by days to weeks; switching-over of fuel gas at facilities other than boiler, and logical assignment of off-days to each plant, and

3) by months and longer terms; readjustment of operational conditions and review of production schedule.

Even then, however, there will always remain some fluctuation that cannot be absorbed by those means, and how to execute the final management is the problem.

For example, the quantity of the excess gas can vary from the normal $660 \times 10^{6} \mathrm{kcal} / \mathrm{h}$ of the TGT operation to $622 \times 10^{6}$ of the banking of one $\mathrm{BF}$ or to $768 \times 10^{6}$ of the scheduled stopping of the hot strip mill line. As may be seen in Table 41, this is a fluctuation of as much as $c a .20 \%$. Therefore, whatever method of dispensing those excess gases may be taken, be it straight selling off, to use as the raw material for $\mathrm{C}_{1}$ chemistry, or conversion to electricity, it must be the one that can absorb that much variance. One way of doing this is to assign this function to the power boiler as exemplified by the two illustrations in Fig. 23 , but then some auxiliary fuel need be purchased in either case.

\section{Management of Electric Power}

It was shown in Chapter $I V$ that, as far as the monthly average goes, some $261.5 \times 10^{6} \mathrm{kWh} /$ month of elec- 
tricity can be generated on the excess gas and recovered energies, and that after supplying the total power demand of $225.6 \times 10^{6} \mathrm{kWh}, c a .36 \times 10^{6} \mathrm{kWh} /$ month (13.8\% of the indigenous generation) may be sold off to outside. However, the actual situation does not revolve on the monthly balance, and what is more critical is the hourly balance.

Consider now the power demand by monthly average, one hour average, and instantaneous peak. Then, the power demand on the TGT operation will be:

$\begin{array}{lccc} & \begin{array}{c}\text { Monthly } \\ \text { average }\end{array} & \begin{array}{c}\text { One hour } \\ \text { average }\end{array} & \begin{array}{c}\text { Instantane- } \\ \text { ous peak }\end{array} \\ \begin{array}{l}\text { Power demand } \\ \text { in MW }\end{array} & 309 & 364 & 516 \\ \text { Factor } & 1.00 & 1.18 & 1.67\end{array}$

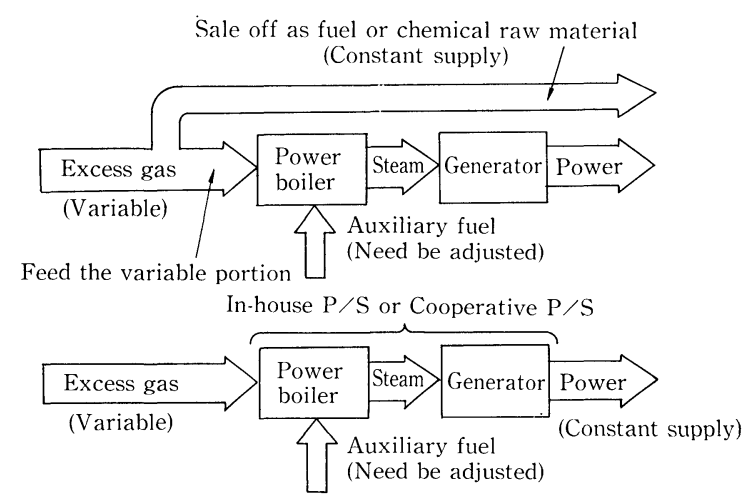

Fig. 23. Effective utilization of excess gas by power boiler system.
This means that in order to ensure the supply of the average power demand of $309 \mathrm{MW}, 516 \mathrm{MW}$, or a factor of 1.67-times, is actually needed at any given time. Nevertheless, the in-house power generation on byproduct gases and recovered energies is able to cover only $358 \mathrm{MW}$. Therefore, some auxiliary fuel must be fed to the power boiler to fill up this gap. For this, following 4 cases are possible as shown in Fig. 24.

Case 1: Generate the power in-house to a certain level, and purchase the remainder from outside. In this case, a considerable amount of gas becomes excess, which will have to be sold off or otherwise be dealt with.

Case 2: Generate the power in-house up to the limit of excess energy. This will necessitate to purchase power to bridge over the peak demand, and conversely, during the time of low load, reverse flow of power will occur.

Case 3: Generate the power up to the peak. Purchase of power is no longer necessary, but auxiliary fuel must continually be consumed and, on top of it, the power reverse flow will become greater.

Case 4: Generate the power to a certain level beyond the peak. In this case, a certain amount of power can be sold off constantly, but a large quantity of auxiliary fuel will be needed.

Thus, some auxiliary fuel will have to be brought in to manage the demand/supply gap effectively and economically for fluctuations of byproduct gas generation and occurrence of peaks in power demand. Of course, the power consumption is desirably uniform

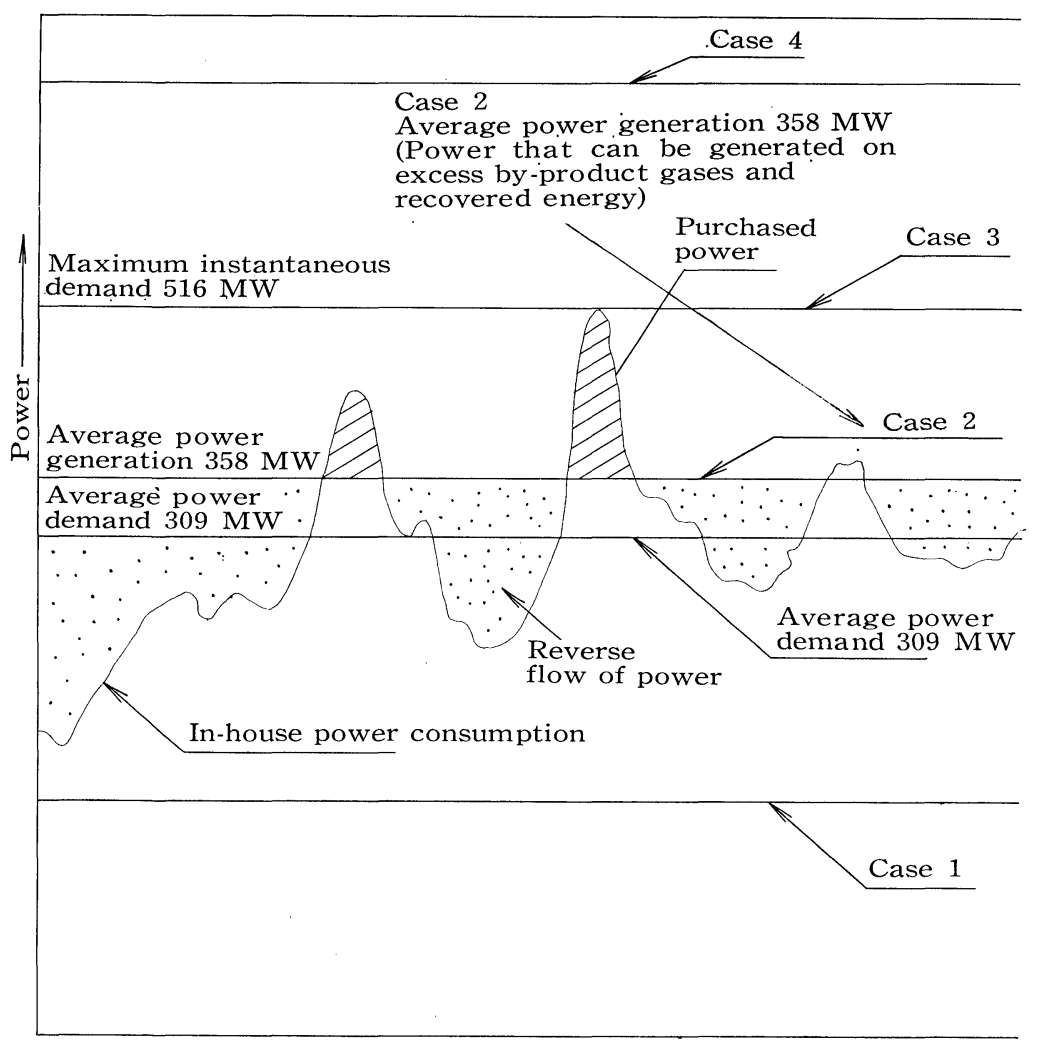

Time
Fig. 24.

Four cases of power supply/demand for integrated steel works. 
throughout the works, for which purpose adjustment of the rolling mill loads, assignment of off-days to rolling plants, storage of energy in the form of products (e.g., manufacture of ferroalloys by electric furnace, manufacutre of liquid oxygen at oxygen plant, etc.) can all be an effective measure.

\section{Some Thoughts on Power Facilities and Energy Re- covery}

1. Improvement of Energy Conversion Efficiency of Power Facilities

The power facilities are those apparatuses that convert byproduct gases into electricity or steam, and electric power into compressed air, oxygen, pressurized water, and such. As the energy that is being expended by those facilities amounts to over $30 \%$ of the total, the conversion efficiency can directly affect the total energy efficiency. Among those, the greatest is the in-house power generation facilities, which, due to the rapid rise of the energy cost, can now be process-designed for efficiency rather than for economy.

For example, conventionally, the thermal power stations of medium size, e.g., $75 \mathrm{MW}$ or less, are equipped with a turbine system of 4-stage extraction, regenerative cycle type with only the air preheated. This system develops a heat rate of $2638 \mathrm{kcal} / \mathrm{kWh}$ and an overall efficiency of $32.6 \%$. If a 5-stage extraction, reheating and regenerative cycle type system with both the air and the fuel gas preheated is to be used, however, the heat rate will be as small as $2299 \mathrm{kcal} /$ $\mathrm{kWh}$ and the efficiency $37.4 \%$, a remarkable $13 \%$ improvement in the conversion efficiency. This is illustrated in Table 42. In the case of the present Model Works operating on TGT, this difference can amount to as much as $27 \times 10^{6} \mathrm{kcal} / \mathrm{kWh}$, an amount that surpasses the energy saving achievable with allout dry coke quenching (CDQ).

If a gas turbine combined cycle plant, such as shown in Fig. 25 is to be installed, furthermore, an overall power generation efficiency of 37.0 to $39.5 \%$ can be attained.

\section{Recovery of Waste Energy and Effective Utilization}

Before attempting waste energy recovery, the input energy should be decreased first. Then, for any waste energy that still remains over, such recursive type heat recovery as preheating of the combustion air and the fuel gas should be considered. The waste energy yet remaining after those steps have been taken will have to be recovered as a source for other processes. Here, from the recovery efficiency and the return-on-investment viewpoints, the preference should be placed on the use first as the heat for preheating or drying, second as steam, and third as electric power.

In the case of the TGT operation of the present Model Works, adoption of various energy saving measures has been presumed to have preceded recovery. For example, the heats recovered from coke and slag

Table 42. Improvement of power generation efficiency by adopting gas preheating, reheating/regenerative cycle.

\begin{tabular}{|c|c|c|c|}
\hline & & $\begin{array}{c}100 \mathrm{~kg} / \mathrm{cm}^{2} \mathrm{G} \times 500^{\circ} \mathrm{C} \\
\text { Regenerative cycle } \\
\left(\begin{array}{l}4 \text { stage steam } \\
\text { extraction }\end{array}\right) .\end{array}$ & $\begin{array}{l}100 \mathrm{~kg} / \mathrm{cm}^{2} \mathrm{G} \times 500^{\circ} \mathrm{C} \\
\text { Reheating } / \text { regenerative } \\
\text { cycle } \\
\left(\begin{array}{l}5 \text { stage steam } \\
\text { extraction }\end{array}\right)\end{array}$ \\
\hline \multicolumn{2}{|r|}{$\begin{array}{c}\text { System schematic } \\
\text { diagram }\end{array}$} & Boiler $100 \mathrm{~kg} / 2$ & Foed water heater water \\
\hline \multirow{2}{*}{ 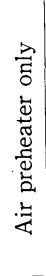 } & $\begin{array}{c}\text { Boiler subsystem } \\
\text { diagram }\end{array}$ & Boiler $t_{1}=$ & $\begin{array}{l}\text { Exhaust } \\
\text { Air } \\
\text { BFG, COG }\end{array}$ \\
\hline & $\begin{array}{l}\text { Efficiencies }(\%) \\
\text { Turbine } \\
\text { Boiler } \\
\text { In-plant } \\
\text { Overall } \\
\text { Energy conversion } \\
\text { (kcal/kWh) }\end{array}$ & $\begin{array}{r}40.3 \\
87.3 \\
7.0 \\
32.6 \\
2638\end{array}$ & $\begin{array}{c}43.07 \\
85.4 \\
6.0 \\
34.6 \\
2486\end{array}$ \\
\hline \multirow{2}{*}{ 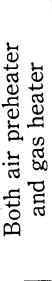 } & $\begin{array}{c}\text { Boiler subsystem } \\
\text { diagram }\end{array}$ & \multicolumn{2}{|c|}{$\begin{array}{c}\text { Main Reheated Gas heater } \\
\text { steam }\end{array}$} \\
\hline & $\begin{array}{l}\text { Efficiencies }(\%) \\
\text { Turbine } \\
\text { Boiler } \\
\text { In-plant } \\
\text { Overall } \\
\text { Energy conversion } \\
\text { (kcal/kWh) }\end{array}$ & $\begin{array}{r}40.3 \\
92.5 \\
7.0 \\
34.7 \\
2478\end{array}$ & $\begin{array}{c}43.07 \\
92.4 \\
6.0 \\
37.4 \\
2299\end{array}$ \\
\hline
\end{tabular}

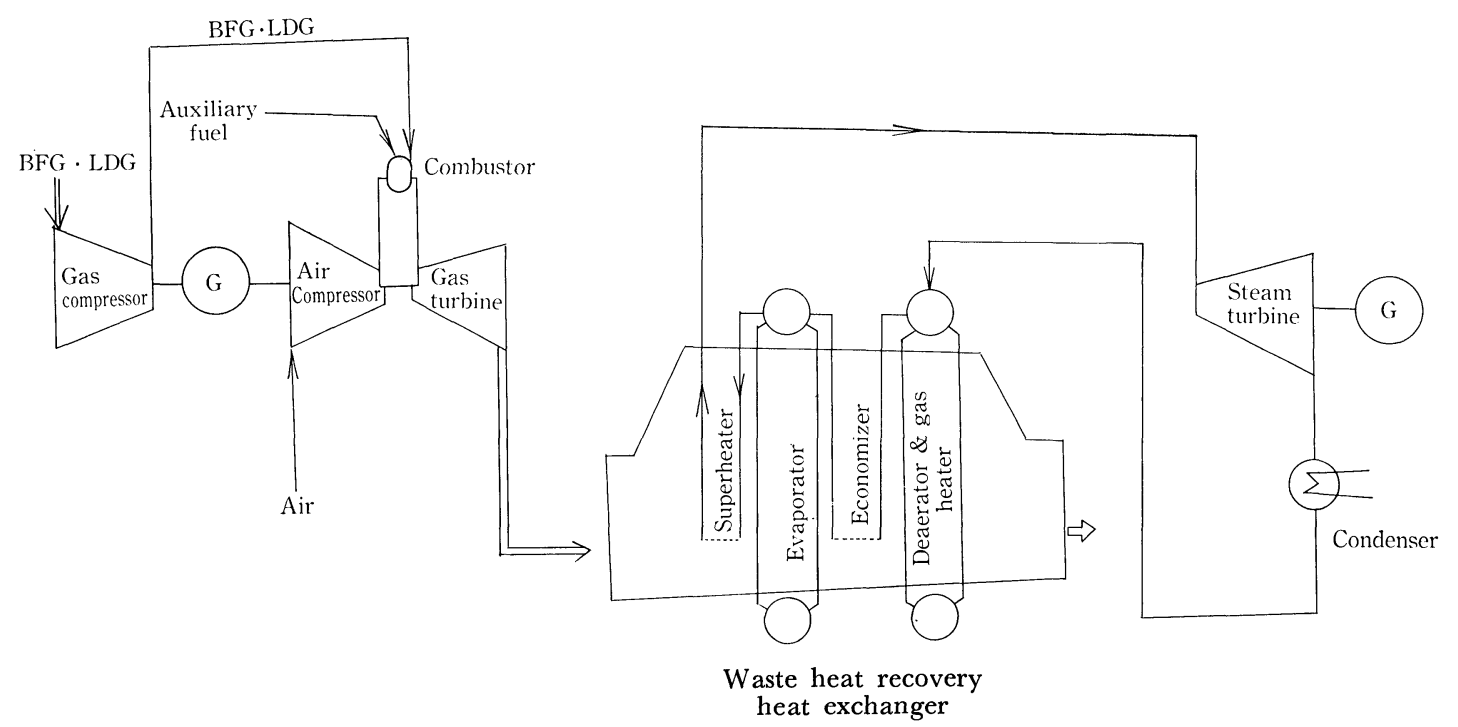

Fig. 25. Gas turbine combined cycle plant. 
are to be utilized either as steam or as electric power flexibly and in accordance with the existing energy situation.

To practice heat recovery most efficiently and to utilize the recovered heat most effectively, pre-examination of

1) which one of the sources is the best for steam, and which one for electricity,

2) which is the most appropriate recovery system and what the steam condition should best be, and

3) how to accomodate the changes in steam demand and the occurrence of waste heat that are expected in future

is necessary. For this, making up of a map that shows in a glance the status quo of waste heat generation and steam demand at various plants and shops and building up of a comprehensive energy system that includes the power stations are highly effective.

\section{Conclusion}

Fundamental notions and limitations of energy saving technologies, changes in energy structure, and problems to accompany those changes have been discussed for a hypothetical 8 million $\mathrm{t}$ class integrated iron- and steel-making works as a model. The conclusion that has been reached by the Energy Saving Technologies Research Group, the Heat Economy Technology Committee, the Joint Research Society of the ISIJ is:

Furtherance of such basic studies as how to improve the efficiency of individual energy apparatuses and how to determine the calorific value of a fuel gas for a particular application is of course necessary, but what is more important for the future is how to construct a cost minimum energy supply system, a system which shall be adaptable to changes in the energy situation.

\section{Nomenclature}

$\mathrm{BF}$ : blast furnace

BFG: blast furnace gas

BOF : basic oxygen furnace (or LD converter)

GG: continuous casting

CGG: continuous continuous casting

GCR: continuous casting rate (\%)

CDQ: coke dry quenching

GBR: coke breeze rate ( $\mathrm{kg} / \mathrm{t}$-sinter)

COG: coke oven gas

CR: coke rate $(\mathrm{kg} / \mathrm{t}$-pig)
CUR: capacity usage rate $(\%)$

CV: calorific value ( $\mathrm{kcal} / \mathrm{kg}$ or $\mathrm{Nm}^{3}$ )

FR: fuel rate ( $\mathrm{kg} / \mathrm{t}$-pig, -crude steel, or -product)

HCR: hot charge rolling

HMR: hot metal ratio (\%) (or hot metal rate)

HDR: hot direct rolling

IC: ingot cast

LDG: LD converter gas

OR: oil rate $(\mathrm{kg} / \mathrm{t}$-pig)

OG: off gas, particularly from a $\mathrm{BOF}$

PR: power rate $(\mathrm{kWh} / \mathrm{t}$-steel)

STD: standard

TGT: target

TR: tapping rate $\left(t / \mathrm{m}^{3}\right.$ (inner volume)-day)

TRT: top-pressure recovery turbine

VM: volatile matter (of coal) $(\%)$

\section{Abbreviation}

IISI: International Iron and Steel Institute

ISIJ: The Iron and Steel Institute of Japan

JISF: The Japan Iron and Steel Federation

MITI: Ministry of International Trade and Industry

\section{Acknowledgements}

We acknowledge sincerely the aids, advices and guidances given us by our fellow members of the Energy Saving Technologies Research Group throughout preparation for this Lecture. Kind help and encouragement extended to us by the ISIJ Editorial Staffs are gratefully appreciated.

\section{REFERENCES}

1) Report submitted to the Joint Research Society of ISIJ by the Energy Saving Technologies Research Group, the Heat Economy Technology Committee, "Energy Saving at Integrated Steel Works-Estimation of Limits and Visions for Future Energy Structure", (November, 1980), (limited circulation report).

2) T. Yamamoto: Tetsu-to-Hagané, 68 (1982), 49.

3) A. Rist and N. Meysoon: Rev. Mét., 62 (1965), 995.

4) I. Muchi: Seitetsu Kagaku Enshu (Applications of Ironmaking Chemistry), Yokendo, Tokyo, (1974).

5) A. Shigemi: Seitetsu Handbook (Handbook for Ironmaking), Chijin Shokan, Tokyo, (1979).

6) Report submitted to the Joint Research Society of ISIJ by the Ingotmaking Research Group (49th Meeting), November, 1979), (limited circulation report).

7) Report submitted to the Joint Research Society of ISIJ by the Hot Strip Research Group (28th Meeting), (March, 1978), (limited circulation report). 